by Debajyoti Paul ${ }^{*}$, Jyoti Chandra ${ }^{2}$, Mahesh Halder ${ }^{1}$

\title{
Proterozoic Alkaline rocks and Carbonatites of Peninsular India: A review
}

\author{
${ }^{1}$ Department of Earth Sciences, Indian Institute of Technology Kanpur, Kanpur 208016, Uttar Pradesh, India \\ ${ }^{2}$ CSIR-National Geophysical Research Institute, Hyderabad 500007, Telangana, India \\ *Corresponding author, E-mail address: dpaul@iitk.ac.in (D. Paul), Tel: +91-512-259-6169, Fax: +91-512-259-6469
}

(Received : 6/08/2019; Revised accepted : 14/10/2019)

https://doi.org/10.18814/epiiugs/2020/020015

The alkaline rocks and carbonatites (ARCs) of the Great Indian Proterozoic belt bear the testimony of tectonic processes operating in the Proterozoic during the continental assembly and breakup of both Columbia and Rodinia. We present a comprehensive review, mainly focused on the petrology, geochemistry, and geochronology of 38 ARCs of Peninsular India, which are mostly concentrated within the Eastern Ghats Mobile Belt and Southern Granulite Terrain. Available geochronologic data reveals three distinct alkaline magmatic phases (2533-2340 Ma, 1510-1242 Ma, 833$572 \mathrm{Ma}$ ) and two metamorphic events (950-930 Ma and 570-485 Ma) that correlate with the Grenvillian and PanAfrican orogeny events. Whereas clinopyroxene, amphibole, titanite and apatite fractionation seems to have affected the nephelinite, nepheline syenite and syenite, carbonatite is affected by fractionation of calcite, dolomite, ankerite, pyroxene, apatite, magnetite, mica, and pyrochlore. Trace elements and $\mathrm{Sr}-\mathrm{Nd}-\mathrm{Pb}-\mathrm{C}-\mathrm{O}$ isotopic compositions of these ARCs strongly suggest a subcontinental lithospheric mantle source, that is enriched either by distribution of subducted crustal material or by metasomatism of mantle-derived fluids, for the generation of ARCs. Despite some isotopic variability that can result from crustal contamination, a trend showing enrichment in ${ }^{87} \mathrm{Sr}^{\beta 6} \mathrm{Sr}_{i}(0.702$ to 0.708$)$ and depletion in $\varepsilon_{N d(i)}(-1.3$ to -14.1$)$ over a $2 \mathrm{Gyr}$ duration indicates temporal changes in the lithospheric/ asthenospheric source of ARCs, due to periodic enrichment of the source by mantle-derived fluids. ARC generation starts in an intracontinental rift setting (beginning of Wilson cycle). These early-formed ARCs are carriedto $100 \mathrm{~km}$ depths during continental collision (termination stage of Wilson cycle) and undergo extensive melting because of renewed rifting along suture zones to form new generation of ARCs.

\section{Introduction}

Alkaline igneous rocks, defined in terms of their total alkali $\left(\mathrm{Na}_{2} \mathrm{O}\right.$ $+\mathrm{K}_{2} \mathrm{O}$ ) and $\mathrm{SiO}_{2}$ compositions, include a wide range of rocks that contain modal/normative alkali-rich minerals such as nepheline, leucite, and sodic pyroxenes and amphiboles (Sørensen, 1974; Streckeisen, 1980; Le Bas et al., 1986). Although, carbonatites do not contain alkali-rich phases such as nepheline, these silica deficient (mostly $\left.\mathrm{SiO}_{2}<10 \%\right)$ rocks are also generally considered with alkaline rocks by virtue of their close association in the field, and normally referred to as alkaline rocks and carbonatites or ARCs (Woolley, 2001; Burke et al., 2003). However, some carbonatite occurrences show no association with the alkaline rocks, e.g., Newania complex in India (Ray et al., 2013). Note that the carbonatite is volumetrically insignificant to the associated alkaline rocks (Ashwal et al., 2016). The ARCs have been reported from three dominant tectonic settings: continental rifts, stable intraplate setting, and collisional or suture zones in subduction settings (Woolley, 2001; Burke et al., 2003, 2008; Leelanandam et al., 2006; Vijaya Kumar et al., 2007; Upadhyay, 2008; Woolley and Kjarsgaard, 2008; Ashwal et al., 2016; Ackerman et al., 2017; Ranjan et al., 2018). In general, majority of the alkaline rocks occur in or near the continental rifts and ocean islands. The combined volume of ARCs globally constitutes < $1 \%$ of all igneous rocks (e.g., subalkaline rocks such as tholeiitic basalt, dacite, andesite, and rhyolite etc.) identified so far, formed throughout the geological history (Sørensen, 1974), and yet have generated research interest because of their tremendous economic (high concentrations of large ion lithophile elements or LILE, REE, $\mathrm{Nb}, \mathrm{P}, \mathrm{Ta}, \mathrm{Cu}$, and $\mathrm{U}$ etc.) potential (Woolley, 2001). However, Proterozoic eon has witnessed significant amounts of alkaline magmatism (Burke et al., 2003, 2008; Ashwal et al., 2016); for example, alkaline rocks found in the Superior Province, Canada (Sutcliffe et al., 1990), Yilgarn Craton, Australia (Smithies and Champion, 1999), Karelia, Russia and Finland (Heilimo et al., 2017), and the Archean/Proterozoic Cratons in the Peninsular India (Leelanandam et al., 2006). Of particular interest are deformed alkaline rocks and carbonatites (DARCs) that characteristically occur in intracontinental rift settings in Africa, concentrated along inferred 
Proterozoic suture zones (Burke et al., 2003; Ashwal et al., 2016). DARCs account for only $<10 \%$ of total ARCs. Although the chemistry of DARCs is identical to that of the ARCs, they differ in terms of structural characteristics in that DARCs show prominent gneissic structure (Burke and Khan, 2006). Using geochronological data, Burke et al. (2003) argued that the DARCs represent two well-defined parts of the Wilson cycle: opening (alkaline rock formation during rifting) and closing of oceans (deformation of early-formed ARCs during continent-continent and arc-continent collisions). This hypothesis of Proterozoic DARCs, representing the imprints of the Wilson cycle, found support from later work (e.g., Burke et al., 2008; Burke and Khan, 2006; Vijaya Kumar et al., 2007; Upadhyay, 2008; Ashwal et al., 2016; Ranjan et al., 2018). Burke et al. (2003) also suggested that the subducted DARCs residing in the mantle lithosphere (depth of $\sim 100 \mathrm{~km}$ ), after collisional events, become potential source of the younger ARCs in the area. This provided a plausible explanation (cf. Bailey, 1977) for the reoccurrence of alkaline magmatism in the same locality over a span of hundreds of millions of years.

Several Proterozoic (deformed) ARCs $(n=47)$ are unevenly distributed within the $4000 \mathrm{~km}$ long, S-shaped, Great Indian Proterozoic Fold Belt in the Peninsular India (Leelanandam et al., 2006). Most of the alkaline rock outcrops occur along the contact between the Archean cratons, Eastern Ghats Mobile Belt (EGMB) and the Southern Granulite Terrain (SGT), and mark the approximate locations of intra-continental rifts that were sutured later during continental collision. These collisional suture zones represent the location of opening of an ocean around $2000 \mathrm{Ma}$, followed by several Proterozoic continental and arc-system collisions during 2000 Ma to $550 \mathrm{Ma}$ (Leelanandam et al., 2006; Upadhyay, 2008 and references therein). The south-eastern margin of India has faced several collisional (with East Antarctica) and breakup events during supercontinent assembly in Proterozoic (Simmat and Raith, 2008; Upadhyay, 2008 and references therein). Alkaline rocks were emplaced during continental rifting and ocean opening, and experienced several imprints of tectono-metamorphic events caused by the collisions developed by Grenvillian (1400-1000 Ma) and Pan-African (600$500 \mathrm{Ma}$ ) orogeny (Upadhyay, 2008).

Although the geographical occurrences of Indian Proterozoic ARCs and a link with rifted continental margins and younger suture zones have been established by several workers, the petrogenesis of these ARCs and their precursor magmas from putative sources (whether deep mantle or continental lithospheric mantle) have not been clearly established, mostly due to lack of robust age constraints and geochemical data. As a result, a number of possibilities have been suggested for the origin of parental ARC magma, similar to that proposed for elsewhere. These include partial melting of metasomatized and enriched lithospheric mantle (Fitton and Upton, 1987), melting of asthenospheric mantle (Menzies, 1987), and partial melts from lower crustal source contaminated with upper crustal material (Smithies and Champion, 1999) etc. Geochemical data, in conjunction with field relations and petrography, available for a number of Proterozoic alkaline exposures in India provide an opportunity to evaluate the geodynamic evolution of these ARCs in the context of plate tectonics during Proterozoic (Leelanandam et al., 2006; Upadhyay, 2008 and references therein). Leelanandam et al. (2006) have presented a comprehensive study of the Proterozoic alkaline rocks (mainly occurrences of nepheline syenite and carbonatite) of India, primarily focused on the geological distribution of these rocks and tectonic evolution related to continental rifting and mountain building processes in the Proterozoic. The present study primarily aims to collate and evaluate geochronological and geochemical information to draw inferences on the origin of Indian Proterozoic ARCs. Unless otherwise stated, discussion on ARCs also include the DARCs. Here, we have compiled geochemical data for mainly nepheline syenite, syenite, nephelinite, and carbonatite along with other rock types such as monzonite, alkali pyroxenite, and alkali granite etc. This study excludes lamprophyre, lamproite, and kimberlite, the ultramaficalkaline rocks, which are addressed by others in this issue. The purpose of this work is to (i) review the existing literature and highlight the present state of knowledge on Proterozoic ARCs in India, (ii) compile available geochemical data (major oxides, trace elements abundances, $\mathrm{Sr}-\mathrm{Nd}-\mathrm{Pb}-\mathrm{O}-\mathrm{C}$ isotope compositions) and analyse the geochemical signatures in these ARCs, and (iii) identify the plausible sources of these ARCs and propose a likely petrogenetic model.

\section{Occurrences, geological settings, and field aspects of Proterozoic (deformed) ARCs in India}

Occurrences of (deformed) ARCs of Proterozoic age in India are well known for the last three decades (Santosh et al., 1989; Natarajan et al., 1994; Kumar et al., 1998; Upadhyay et al., 2006a, b; Upadhyay, 2008; Mukhopadhyay et al., 2011a; Renjith et al., 2014; Chakrabarty et al., 2016; Hippe et al., 2016; Ackerman et al., 2017; Das et al., 2018; Ranjan et al., 2018). Approximately 60 alkaline complexes including carbonatite, lamprophyre and lamproite rocks have been identified in Rajasthan, and mainly in the eastern and southern Indian states of Bihar, Odisha, West Bengal, Andhra Pradesh, Telangana, Kerala, Karnataka, and Tamil Nadu (Mazumder et al., 2000; Leelanandam et al., 2006). Out of these, 47 alkaline rock complexes of Proterozoic age occur within the Great Indian Proterozoic Fold Belt that follows the strike of highly deformed Proterozoic granulites and gneisses (Leelanandam, 1989; Mazumder et al., 2000; Leelanandam et al., 2006). In this paper, we have focused on 38 (deformed) ARC exposures for which geochemical and geochronological data are available in the literature (Fig. 1, Table 1). Several other ARCs, for example Ariyalur in Tamil Nadu, Kankarakhol in Odisha, and Kunduluru in Andhra Pradesh (Leelanandam et al., 2006) have been excluded due to inadequate geological, geochemical, and geochronological information on these complexes.

In general, Proterozoic ARCs occur as rounded intrusions, whereas DARCs occur as concordant lenses within gneisses and granulites (Burke and Khan, 2006). Alkaline complexes of West Bengal, Odisha, and Andhra Pradesh are mainly exposed at the contact of EGMB (3900-2500 Ma, see Table 1 of Dasgupta et al., 2013) with several Archean cratons such as the Singhbhum Craton ( 3550 Ma; Goswami et al., 1995) and the Bastar Craton (3560 Ma; Ghosh, 2004). Alkaline complexes in Tamil Nadu and Kerala are concentrated within the NE-SW trending major faults in the Southern Granulite Terrain (SGT; Table 1). However, Kishangarh and Newania complexes are exposed in the Aravalli Craton (3000-700 Ma, Choudhary et al., 1984), which comprise nepheline gneiss and carbonatite, respectively (Niyogi, 1966; Crawford, 1970; Viladkar and Wimmenauer, 1986). The Newania carbonatite complex, $5 \mathrm{~km}$ long and $0.5 \mathrm{~km}$ wide, is associated with the NE-SW trending Aravalli Rift (Viladkar and Wimmenauer, 1986). This carbonatite, a rare variety in India, are not 


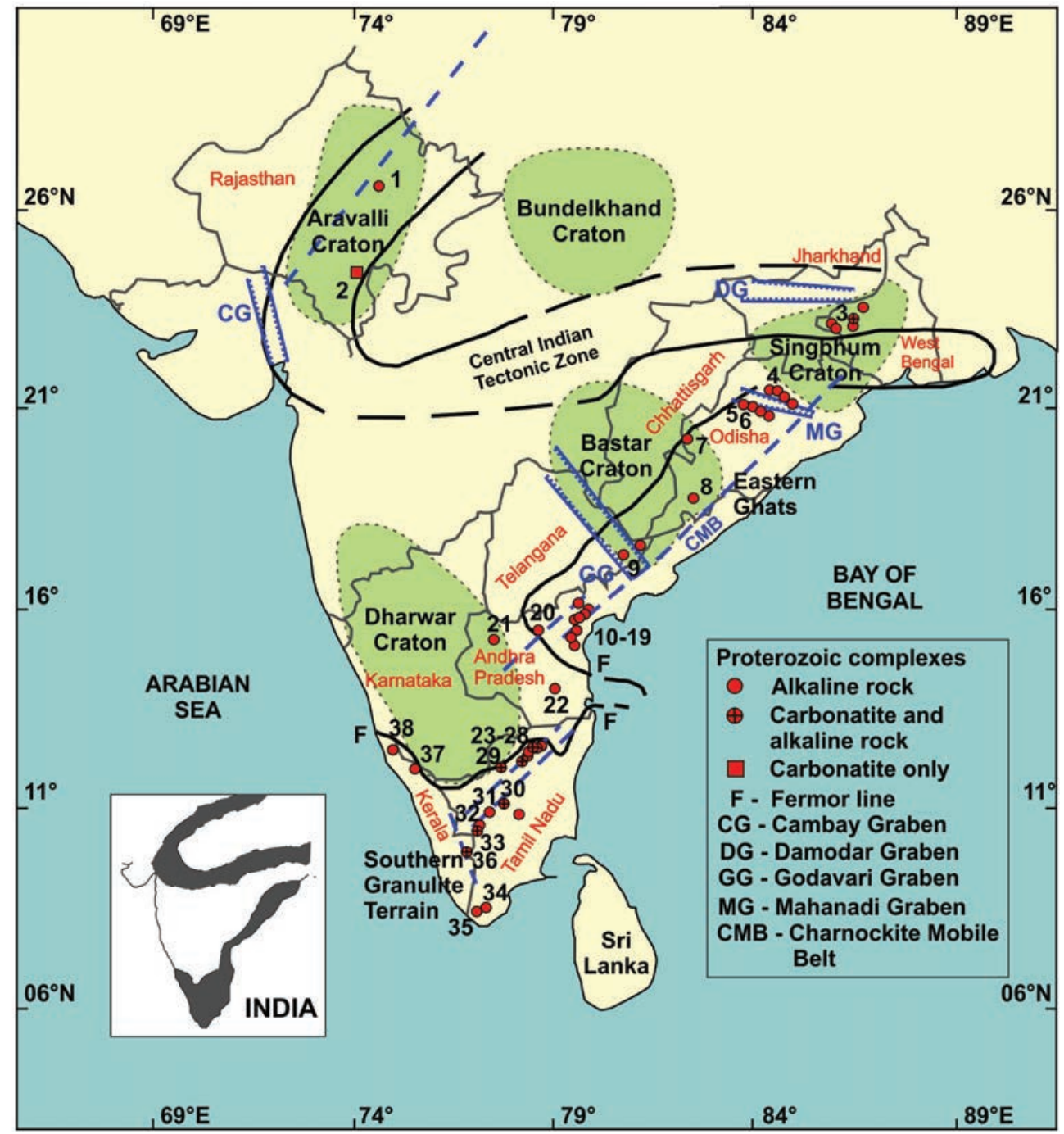

Figure 1. Geological map of India showing occurrence of Proterozoic alkaline rocks and carbonatites (redrawn after Leelanandam et al., 2006). Also shown are the major Precambrian cratons in the Indian shield (Naqvi and Rogers, 1987). Inset shows a $4000 \mathrm{~km}$ long S-shaped mountain belt (Radhakrishna and Naqvi, 1986; Leelanandam et al., 2006). Locations of grabens are adopted from Leelanandam (1990). Major structures, e.g. Cambay Graben, Damodar Graben, Godavari Graben, Mahanadi Graben, and Charnockite mobile belt represented as blue dashed lines are adopted from Krishnamurthy et al. (2000), and F represents the Fermor line adopted from Fermor (1936). Numbers on each dot of Proterozoic complex are described in Table 1. Few Proterozoic complexes, shown without numbers, have not been adequately described and hence excluded from this study.

associated with any alkaline silicate host rocks. Carbonatite occurs as oblong shaped intrusive body and comprise predominantly magnesian rauhaugite (dolomitic carbonatite), ankeritic carbonatite, and minor calciocarbonatite as dykelets within dolomite and ankeritic carbonatite (Viladkar and Wimmenauer, 1986). The Purulia complex contains multiple isolated exposures of alkaline bodies in form of sigmoidal outcrops and dykes (Mitchell and Chakrabarty, 2012; Basu and Bhattacharyya, 2014), which are exposed in the SanturiKankarkiari area (Das et al., 2018), Sushina Hill (Chakrabarty et al., 2016), and Beldih (Chakrabarty and Sen, 2010). Beside these three exposures, alkaline rock complexes of Proterozoic eon are mainly concentrated in the EGMB and SGT (Fig. 1). In case of carbonatite complexes, total ten exposures of Proterozoic age have been recognized in India (Fig 1): Kambamettu or Kambam (2470 Ma; Renjith et al., 2016b), Hogenakal (2400 Ma; Kumar et al., 1998),
Newania (1473 Ma; Ray et al., 2013), Purulia (>1300 Ma; Chakrabarty, 2009), Sevattur (801 Ma; Schleicher et al., 1997), Jokipatti and Samalpatti (770 Ma and $700 \mathrm{Ma}$; Moralev et al., 1975), Elagiri (757 Ma; Mukhopadhyay et al., 2011b), Pakkanadu-Mulakkadu (750 Ma; Möller et al., 2001), and Munnar (740 Ma; Odom, 1982). The Newania and Purulia carbonatite complexes are located in Rajasthan and West Bengal, respectively, whereas the rest of the complexes are located in Tamil Nadu (see Table 1 for details).

\section{Alkaline rock complexes of EGMB}

The EGMB is a northeast trending $\sim 1000 \quad \mathrm{~km} \quad$ long discontinuous array of different lithotectonic units, subdivided into four major zones, namely the khondalite zone (KZ), migmatite zone (MZ), western charnockite zone (WCZ), and the transition zone (TZ) (Ramakrishnan et al., 1998; see Fig. 1 of Dasgupta et al., 2017). The WCZ comprises two granulite terranes: Rengali and Jeypore Provinces. The (deformed) ARCs are located near the boundary of WCZ, KZ and TZ. Proterozoic DARCs, mostly occurring in the EGMB in Andhra Pradesh and Odisha, are thought to be first emplaced in an intracontinental rift setting within a few tens of kilometres of a single suture zone (Leelanandam et al., 2006). Leelanandam (1990) observed that almost all DARC occurrences of EGMB lie close to the Fermor's line (Fermor, 1936), which bounded the charnockite occurrences with a causal connection of regional tectonics (Fig.1). These complexes are located at the contact between the EGMB and the Archean cratons, which is referred as the terrane-boundary shear zone or crustal suture indicating collision between eastern India and east Antarctica (Mezger and Cosca, 1999; Bhadra et al., 2004; Leelanandam et al., 2006; Vijaya Kumar et al., 2007; Upadhyay, 2008; Ranjan et al., 2018). Generally, alkaline rocks along the EGMB are emplaced in a variety of host rocks, e.g., mica schist, calc-silicate, metabasite, quartzite, amphibolite, biotite gneiss, migmatite, phyllite, granite gneiss, and khondalites (Table 1).

The ARC complexes in Odisha, Telangana, and Andhra Pradesh are distributed in form of plutons, lenticular/elliptical bodies, dykes, veins, and lenses (Table 1). The Chhatabar-Lodhajhari-Baradangua, Rairakhol, and Kamakhyanagar alkaline exposures in Odisha are present along the Mahanadi Graben in the form of narrow elongated 


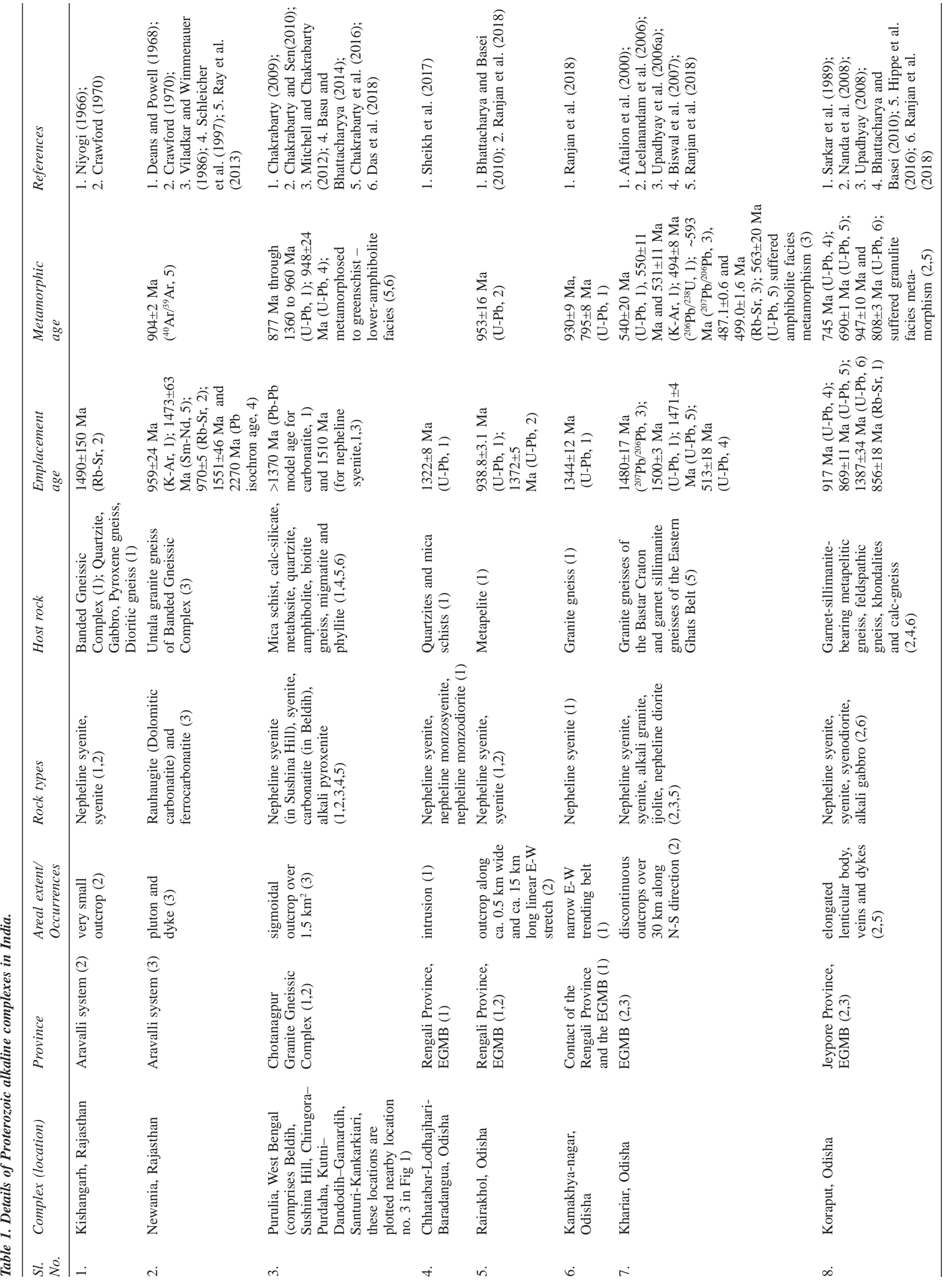




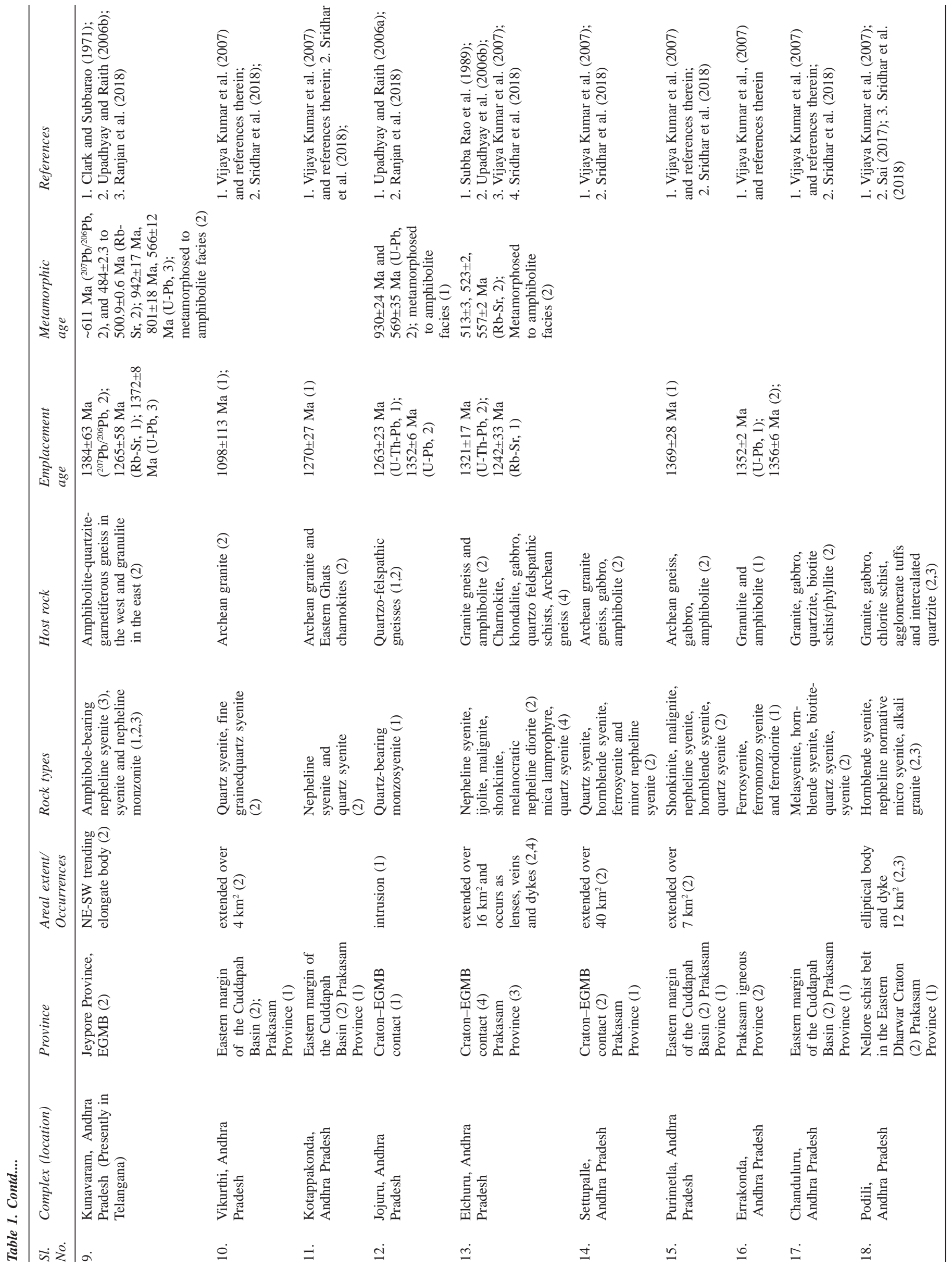




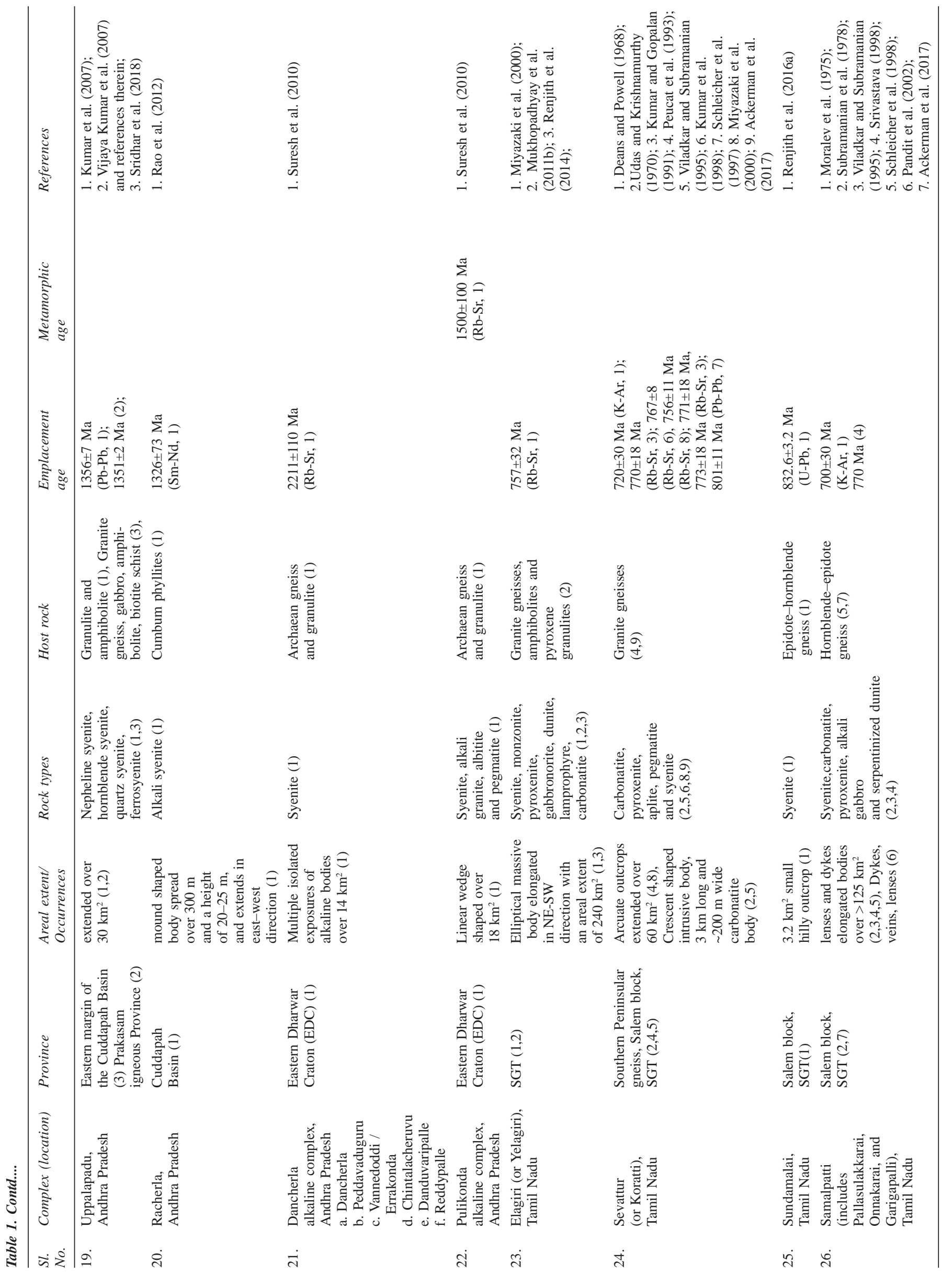




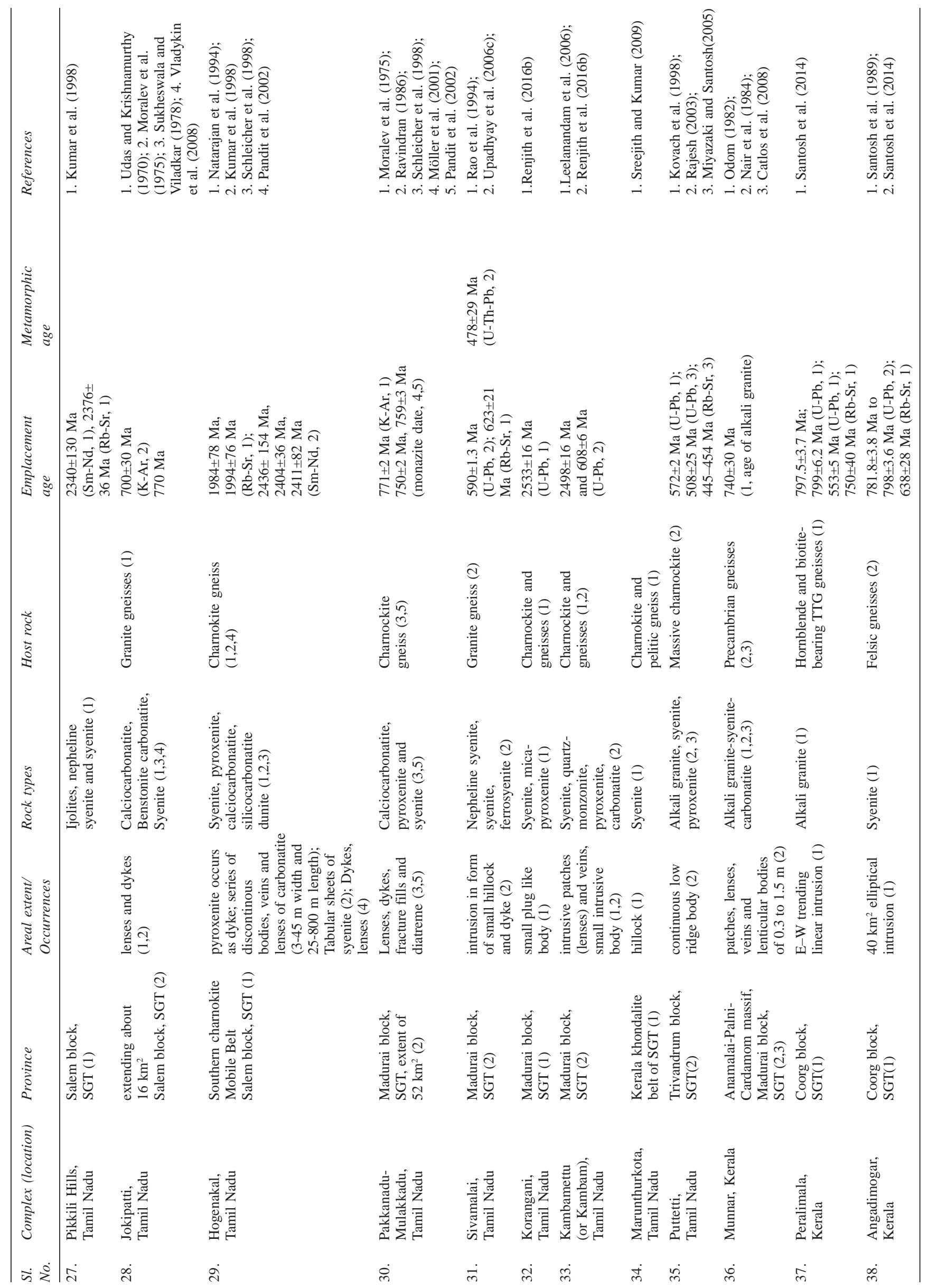


lenticular intrusive units (Fig. 1, Table 1). The Koraput (Odisha) and Kunavaram (Telangana) alkaline complexes are located within the Jeypore Province, whereas the Rairakhol (Odisha) complex is near the eastern margin of the Rengali Province (Upadhyay, 2008). The Khariar (Odisha) alkaline complex intrudes the granites of the Bastar Craton (Upadhyay et al., 2006a). Prakasam Igneous Province in Andhra Pradesh contains Vikurthi, Elchuru, Settupalle, Uppalapadu, Podili, Purimetla, Errakonda, Kotappakonda, and Chanduluru alkaline complexes, which are located near the Vinjamuru domain to the south of the Godavari Graben (Fig. 1; Vijaya Kumar et al., 2007; Upadhyay, 2008). Alkali syenite of the Racherla complex in Andhra Pradesh is exposed within the Cumbum phyllites of the Cuddapah Basin (Chalapathi Rao et al., 2012). Pulikonda and Dancherla alkaline exposures in Andhra Pradesh are present in the Eastern Dharwar Craton (EDC), and south and southwest of Cuddapah Basin (Suresh et al., 2010). Similar to Purulia complex that contains multiple isolated exposures of alkaline bodies, Dancherla complex contains multiple syenite bodies (Suresh et al., 2010; Table 1).

\section{Alkaline rock complexes of SGT}

The SGT of India is divided into six major crustal blocks: Coorg, Nilgiri, Madras, Madurai, Trivandrum, and Nagercoil (Naqvi and Rogers, 1987; Collins et al., 2014). The region between south of the Archean Dharwar Craton (or below the 'Fermor line') and the north of the E-W trending and $>100 \mathrm{~km}$ wide Palghat-Cauvery shear zone (PCSZ), is termed as the Salem Block (comprises Coorg, Nilgiri, and Madras Blocks) or the Northern Granulite Terrain (Collins et al., 2014). The Salem Block is dominated by Archaean/Palaeoproterozoic orthogneisses, metasedimentary rocks, and pyroxene-bearing granite (charnockites), granite gneisses, migmatites, and alkaline complexes (Collins et al., 2014 and references therein). The northern part of the Madurai Block is separated into Neoarchean and Paleoproterozoic Units by a curvilinear-shaped Karur-Kambam-Painavu-Trichur shear zone (KKPT; 570-560 Ma; Ghosh et al., 2009). Most of the Neoproterozoic ARCs (Sevattur, Jokipatti, Samalpatti, Sundamalai, Elagiri, Pikkili, Peralimala, and Angadimogar complexes) intrude the Salem Block of SGT (Santosh et al., 2014). These Neoproterozoic ARC suites comprise nepheline syenite, ijolite, pyroxenite, alkali gabbro, alkali granite, and carbonatite in host rocks such as felsic gneiss, TTG gneiss, charnockite gneiss, and granulite (see Table 1 and references therein). In general, ARCs of SGT show close spatial relationship with the regional fault-lineaments or shear planes, e.g., PCSZ, KKPT shear zone ( 570-560 Ma; Ghosh et al., 2009), Achankovil shear zone, and Kambam fault (Santosh et al., 2014; Renjith et al., 2016b). Some Neoproterozoic (Pakkanadu, Sivamalai, Puttetti and Munnar) and Paleoproterozoic (Korangani and Kambamettu) ARCs of Tamil Nadu are located to the south of the Salem-Attur shear zone. In Tamil Nadu, Korangani alkaline complex is located further south of Pakkanadu and Sivamalai along the KKPT shear zone, and intrude the charnockites and gneisses (Renjith et al., 2016b). The Korangani complex comprises syenite and mica pyroxenite alkaline rocks. Kambamettu alkaline complex occurs as a small intrusive unit within the Neoarchaean to Meso-Neoproterozoic charnockite-granite-migmatite gneiss. Kambamettu complex comprises carbonatite, syenite, quartz-monzonite, and pyroxenites (Renjith et al., 2016b).

Most of the carbonatite complexes from Tamil Nadu, namely Sevattur, Jokipatti, Samalpatti, and Pakkanadu-Mulakkadu, are aligned along the $\mathrm{N} 45^{\circ} \mathrm{E}$ trending Koratti fault (Grady, 1971) and intrude host gneissic rocks. Pyroxenite and syenite constitute the main body of these complexes, which also contains minor carbonatite dykes. The presence of pyroxenite and syenite xenoliths in carbonatite and strong fenitization of host pyroxenite rock are common features observed in all carbonatite complexes of Tamil Nadu. Elagiri alkaline complex contains syenite, monzonite, and pyroxenite with minor carbonatite as dykes within the basement gneiss (Miyazaki et al., 2000; Renjith et al., 2014). The Sevattur carbonatite complex occurs as a crescent shaped intrusive outcrop of $3000 \mathrm{~m}$ long and $200 \mathrm{~m}$ wide carbonatite body within granite-gneiss host rock. The Samalpatti carbonatite complex includes nearby carbonatite occurrences, namely Pallasulakkarai, Onnakarai, and Garigapalli carbonatite. Carbonatite occurs as poor isolated mounds, dykes, veins, or lenses within pyroxenite and syenite host rock and hornblende-epidote bearing basement gneisses (Viladkar and Subramanian, 1995; Schleicher et al., 1998; Pandit et al., 2002). The Pakkanadu carbonatite complex includes carbonatite and associated syenite, pyroxenite, and orthoclasites, which have intruded into charnockite, gneiss, and granulite (Schleicher et al., 1998). Carbonatites of the Jokipatti complex, occurs as small lenses that extend up to $300 \mathrm{~m}$ in length and $100 \mathrm{~m}$ in width, and have intruded the host syenite (Sukheswala and Viladkar, 1978). The Hogenakal carbonatite complex occurs as discontinuous veins and lenses within two subparallel NNE trending pyroxenite dykes that intrude the gneissic charnockites (Natarajan et al., 1994; Pandit et al., 2002). Munnar carbonatite occurs as small lenses and patches intruded into the Precambrian gneiss (Nair et al., 1984). Alkali granite and syenite are associated rocks of Munnar carbonatite.

Although diverse rock types are present in Proterozoic alkaline exposures, for simplification, we have divided these rocks into six categories namely nepheline syenite, syenite, nephelinite, mafic rock, high silica rock, and carbonatite depending on geochemical similarity within similar rock types (see Table 2), which is discussed in detail in Section 4.2. Syenite group of rocks include monzosyenite, monzonite, and quartz monzonite besides syenite, whereas nephelinite group of rocks include ijolite, kalsiliticijolite, K-feldspar sonkinite, malignite, nepheline meladiorite, and nepheline monzonite (Table 2). Mafic and high silica rocks mainly constitute pyroxenite and alkali granite, respectively. Similar to that observed in the alkaline complexes from Africa (Burke et al., 2003; Ashwal et al., 2016), nepheline syenite and syenite constitute the most abundant alkaline rocks of the Proterozoic Indian alkaline complexes (Leelanandam et al., 2006; Upadhyay, 2008).

\section{$\overline{\text { Chronological status of Proterozoic }}$ alkaline and carbonatite magmatism}

\section{Emplacement ages of Proterozoic ARCs}

A detailed analysis of available geochronological data reveals three distinct episodes of alkaline magmatism in India during Proterozoic (Table 1 and 3; Fig. 2). The first phase of Proterozoic alkaline magmatism (2533-2340 Ma) was marked by the emplacement of shoshonitic syenite and pyroxenite at $2533 \mathrm{Ma}$ in the Korangani complex, and quartz-monzonite, pyroxenite, and carbonatite at 24702498 Ma in the Kambamettu complex of Tamil Nadu (Renjith et al., 2016b). This was followed by eruption of carbonatite magma at 
Table 2. Proterozoic carbonatite and alkaline rocks from India considered in this study.

\begin{tabular}{|c|c|c|c|}
\hline $\begin{array}{l}\text { Sl. } \\
\text { No. }\end{array}$ & Rock Group & $\begin{array}{c}\text { No. of } \\
\text { samples }(n)\end{array}$ & Rock types \\
\hline 1. & $\begin{array}{l}\text { Nepheline } \\
\text { syenite }\end{array}$ & 63 & $\begin{array}{l}\text { Depleted and Enriched nepheline } \\
\text { syenite, Nepheline syenite gneiss, } \\
\text { Mesocratic nepheline syenite, Leucitic } \\
\text { phonolite }\end{array}$ \\
\hline 2. & Syenite & 146 & $\begin{array}{l}\text { Alkali feldspar syenite, Biotite- } \\
\text { pyroxene-feldspar syenite, } \\
\text { Ferrosyenite, Foid syenite, Feldspar } \\
\text { syenite, Grey syenite, Leuco syenite, } \\
\text { Mafic syenite, Mela syenite, Pink } \\
\text { syenite, Quartz syenite, Quartz alkali } \\
\text { feldspar syenite, Syenite, Monzonite, } \\
\text { Monzosyenite, Quartz monzonite }\end{array}$ \\
\hline 3. & Nephelinite & 16 & $\begin{array}{l}\text { Ijolite, Kalsiliticijolite, K-feldspar } \\
\text { sonkinite, Leucitic fergisute, } \\
\text { Malignite, Nepheline meladiorite, } \\
\text { Nepheline monzonite }\end{array}$ \\
\hline 4. & $\begin{array}{l}\text { High Silica } \\
\text { rock }\end{array}$ & 26 & $\begin{array}{l}\text { Alkali feldspar granite, Alkali granite, } \\
\text { Granodiorite, Melatonalite }\end{array}$ \\
\hline 5. & Mafic rock & 62 & $\begin{array}{l}\text { Alkali basalt, Gabbro, Gabbronorite, } \\
\text { Hornblende gabbro, Monzogabbro, } \\
\text { Olivine gabbronorite, Alkali } \\
\text { pyroxenite, Biotite pyroxenite, Olivine } \\
\text { clinopyroxenite, Olivine-monticellite- } \\
\text { phlogopite-pyroxene rocks, Pyroxenite }\end{array}$ \\
\hline 6. & Carbonatite & 183 & $\begin{array}{l}\text { Calciocarbonatite (or sövite or calcite } \\
\text { carbonatite), dolomitic carbonatite (or } \\
\text { rauhaugite), ferrocarbonatite (or } \\
\text { ankerite carbonatite), silicocarbonatite, } \\
\text { and benstonite carbonatite }\end{array}$ \\
\hline
\end{tabular}

2400-2440 Ma in Hogenakal and syenitic magma at 2340-2380 Ma forming the Pikkili Hills in Tamil Nadu (Kumar et al., 1998). The combined whole rock $\mathrm{Rb}$-Sr and Sm-Nd ages of Hogenakal and Pikkili Hills provide precise isochron ages of $2401 \pm 25$ and $2415 \pm 10 \mathrm{Ma}$ (Kumar et al., 1998). However, Natarajan et al. (1994) reported a whole rock $\mathrm{Rb}-\mathrm{Sr}$ isochron age of $1984 \pm 78 \mathrm{Ma}$ for the Hogenakal carbonatite complex. Another two alkaline complexes, Pulikonda and Dancherla in Andhra Pradesh give whole rock Rb-Sr ages of 1500 $\pm 100 \mathrm{Ma}$ and 2211 $\pm 110 \mathrm{Ma}$, respectively (Fig. 2; Table 1; Suresh et al., 2010). Suresh et al. (2010) argued that these ages are likely younger (resetting age) than the actual emplacement ages as the Rb-Sr system is prone to resetting.

The second phase of alkaline magmatism occurred around 1510$1242 \mathrm{Ma}$ in the Mesoproterozoic (Fig. 2), and is mainly concentrated in Andhra Pradesh, Telangana, Odisha, and West Bengal at the contact of the Singhbhum and Bastar Cratons with the EGMB (Upadhyay, 2008). The second phase can be correlated with the major Mesoproterozoic rifting during 1500-1350 Ma (Upadhyay, 2008; Vijaya Kumar et al., 2011; Dasgupta et al., 2017). Alkaline and carbonatite magmatism around this time also occurred forming the Newania and Kishangarh complexes in Rajasthan (Table 2). The

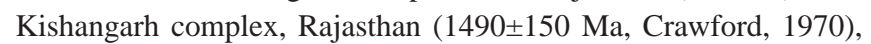
Newania complex, Rajasthan (1473 \pm 63 Ma, Ray et al., 2013) and Khariar Province, Odisha (1480 \pm 17 Ma, Upadhyay et al. 2006a; $1500 \pm 3$ Ma, Aftalion et al., 2000) mark the beginning of alkaline magmatism in the second phase, whereas the Elchuru complex in Andhra Pradesh marks the terminus at $1242 \pm 33$ Ma (Subba Rao et al., 1989; Table 1). The oldest Mesoproterozoic emplacement of alkaline magmatism may have started in Purulia at $1510 \mathrm{Ma}$ (Mitchell and Chakrabarty, 2012). The youngest alkaline magmatism of the second phase may be extended to $1098 \pm 113 \mathrm{Ma}$, which is the age of Vikurthi alkaline complex, Andhra Pradesh (Vijaya Kumar et al., 2007 and references therein). However, detailed geochronological information is not available for Purulia and Vikurthi alkaline complexes (see Table 1), and therefore new geochronological data are required. Upadhyay et al. (2006a, b), Upadhyay and Raith (2006a, b), and Vijaya Kumar et al. (2007) reported a much narrower range of emplacement ages (U-Pb dating of zircons:1480-1262 Ma) for the Khariar, Kunavaram, Elchuru, Jojuru, and Uppalapadu alkaline complexes. Few alkaline complexes such as Elchuru and Kunavaram within the EGMB display wider duration of emplacement ages. The $\mathrm{U}-\mathrm{Pb}$ zircon dates, compared to the $\mathrm{Rb}-\mathrm{Sr}$ isochron dates, provides a tighter constraint on the emplacement ages of the ARC complexes.

The third phase of alkaline magmatism occurred around 833 to $572 \mathrm{Ma}$ (Fig. 2). This phase started with the formation of Sundamalai

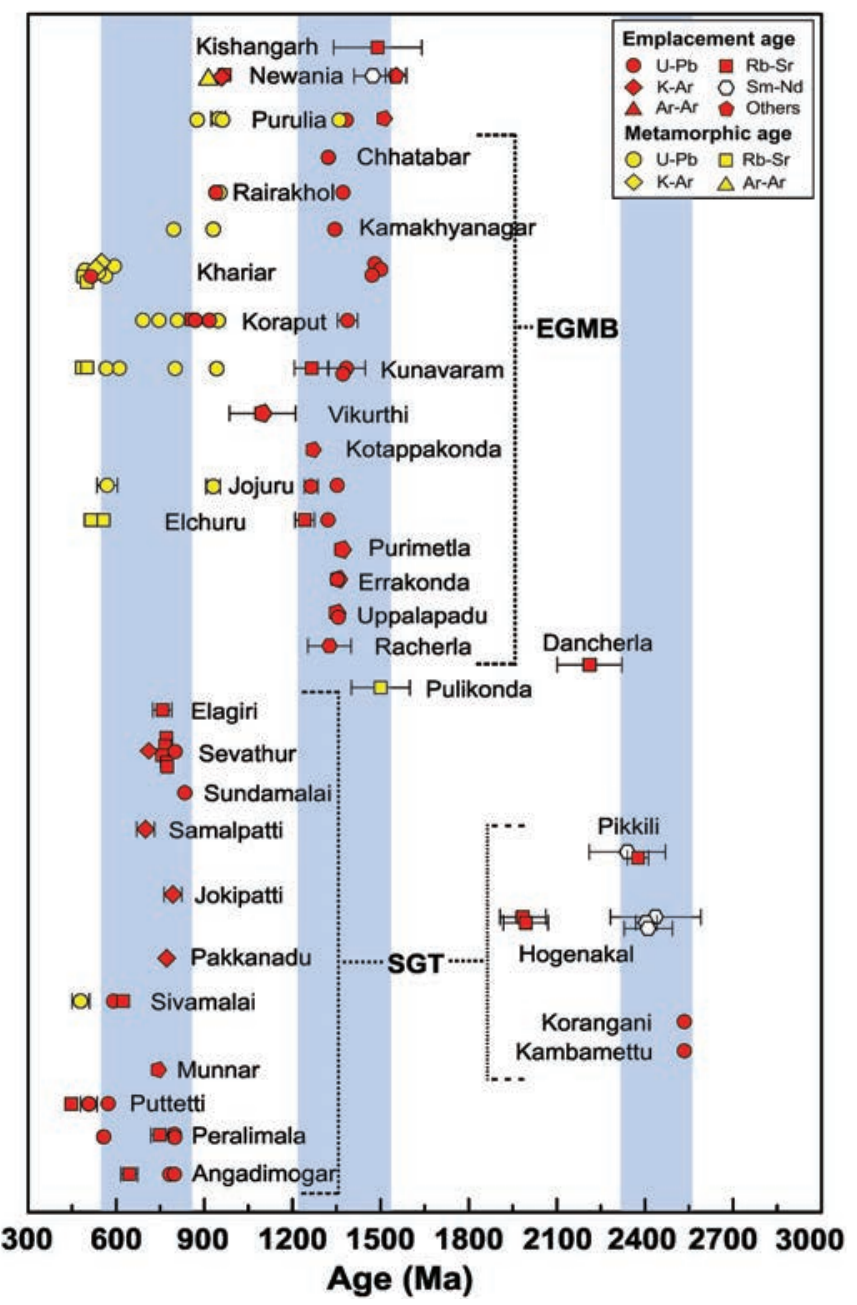

Figure 2. Emplacement ages of Proterozoic alkaline rocks and carbonatites display three prominent episodes of emplacement shown by shadowed regions. Individual data point shows $2 \sigma$ errors on ages; wherever not shown, the size of symbols is larger than the error. EGMB: Eastern Ghats mobile belt; SGT: Southern Granulite Terrain. See Table 1 for details. 
alkaline complex (832.6 $\pm 3.2 \mathrm{Ma}$; Renjith et al., 2016a) and terminated with the emplacement of the Puttetti complex (572 \pm 2 Ma; Kovach et al., 1998), both in Tamil Nadu (Table 1 and 3). Other complexes formed during this magmatic episode are mainly found in Tamil Nadu and Kerala in the SGT (Fig. 2). Deans and Powell (1968) reported a $\mathrm{K}-\mathrm{Ar}$ emplacement age of $720 \pm 30 \mathrm{Ma}$ for the Sevattur carbonatite, obtained on a biotite from biotite-pyroxenite. Kumar and Gopalan

Table 3. Classification of Proterozoic alkaline complexes of India based on their emplacement ages.

\begin{tabular}{lll}
\hline Sl.No. & Proterozoic periods & Proterozoic alkaline complexes \\
\hline 1. & Neoproterozoic & Tamil Nadu: Elagiri, Sevattur, Sundamalai, \\
& Samalpatti, Jokipatti, Pakkanadu, \\
& Sivamalai, Puttetti, \\
& Kerala: Angadimogar, Munnar, Peralimala, \\
& Odisha: Raikhol, Khariar, Koraput \\
& Rajasthan: Newania
\end{tabular}

2. Mesoproterozoic Rajasthan: Newania and Kishangarh

(1510-1242Ma) West Bengal: Purulia,

Odisha: Chhatabar-Lodhajhari-Baradangua, Raikhol, Kamakhyanagar, Khariar, Koraput

Andhra Pradesh: Kunavaram, Vikurthi, Kotappakonda, Jojuru, Elchuru, Purimetla, Errakonda, Uppalapadu, Racherla

3. Paleoproterozoic

Tamil Nadu: Pikkili, Hogenakal, Korangani, (2533-2340 Ma)

Kambamettu

Andhra Pradesh: Dancherla, Pulikonda (?)

(1991) obtained whole rock carbonatite and pyroxenite Rb-Sr ages of $771 \pm 18 \mathrm{Ma}$ and $773 \pm 18 \mathrm{Ma}$, respectively. Schleicher et al. (1997) reported an emplacement age of $801 \pm 11 \mathrm{Ma}$ using ${ }^{206} \mathrm{~Pb} /{ }^{204} \mathrm{~Pb}$ vs. ${ }^{207} \mathrm{~Pb} /{ }^{204} \mathrm{~Pb}$ (whole rock) isochron method on ankeritic carbonatite. The rocks formed during third phase of alkaline magmatism have not experienced high grade metamorphism or strong deformation (Table 1). Evidence of Pan-African metamorphic overprint at $478 \pm 29 \mathrm{Ma}$ has been observed in Sivamalai rocks (Upadhyay et al., 2006c).

\section{Evidence of multiple emplacement ages or Episodic activity of alkaline magmatism}

Available U-Pb detrital zircon ages for few alkaline complexes and carbonatite, reported by others, indicate different emplacement ages, e.g., $~ 860-920$ Ma vs. 1387 \pm 34 Ma for Koraput, 938.8 \pm 3.1 Ma vs. $1372 \pm 5$ Ma for Rairakhol, 513 \pm 18 Ma vs. 1470-1500 Ma for Khariar, $608 \pm 6$ Ma vs. $2498 \pm 16$ Ma forKambamettualkaline complexes, and 959-970 Ma vs. 1473-1551 Ma for Newania carbonatite (Fig. 2, Table 1). Interestingly, younger emplacement ages of Koraput, Newania, and Rairakhol overlap with the metamorphic event of 950-930 Ma, whereas younger emplacement age of Khariar overlaps with another distinct metamorphic event at 570-485 Ma (Fig. 2). Biswal et al. (2007) argued that primary magmatism occurred in Khariar at $513 \pm 18 \mathrm{Ma}$, represented by the $\mathrm{U}-\mathrm{Pb}$ zircon age of nepheline syenite, in contrast to the older age ( 1500-1470 Ma) of this complex proposed by others (Aftalion et al., 2000; Upadhyay et al., 2006a; Ranjan et al., 2018). Ranjan et al. (2018) argued that majority of the U-Pb analyses were performed on recrystallized/ partially reset metamorphic domains or on mixed igneous and metamorphic domain of zircons, resulting in relatively younger age. It is possible that both magmatic ages represent true emplacement ages of alkaline magmatism that occurred in two stages. Older emplacement age may indicate alkaline magmatism during the initial stage of continental rifting around 1500-1350 Ma (Vijaya Kumar and Leelanandam, 2008; Upadhyay, 2008). Later during amalgamation and metamorphism around 850-500 Ma, the second stage of alkaline magmatism occurred when early-formed alkaline rocks acted as potential sources of the younger ARCs; this agrees with the model proposed by others to explain the recurrence of alkaline magmatism in a locality (Bailey, 1977; Burke et al., 2003).

\section{Geochronological signatures of metamorphic imprints}

EGMB has experienced several metamorphic events that are corelatable with the adjacent blocks of the India and East Antarctica (Dasgupta et al., 2017). Alkaline rocks of second phase magmatism show a prominent metamorphic imprint, which is evident in Fig. 2. Majority of these rocks have experienced amphibolite to granulite facies metamorphism (Upadhyay et al., 2006a; Ranjan et al., 2018), which has resulted in a much younger age. The Kamakhyanagar

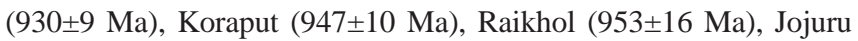
$(930 \pm 24 \mathrm{Ma})$, and Kunavaram (942 $\pm 17 \mathrm{Ma})$ show a common metamorphic age around 950-930 Ma (Table 1). Another distinct metamorphic imprint, during 570-485 Ma, is reported from Khariar ( 485-565 Ma), Jojuru (569 $\pm 35 \mathrm{Ma}$ ), Eluchuru (513 \pm 3 to $557 \pm 2$ ), and Kunavaram $(484.0 \pm 2.3$ to $500.9 \pm 0.6 \mathrm{Ma}, 566 \pm 12 \mathrm{Ma})$ alkaline complexes. Evidence of a metamorphic episode close to 950-930 Ma has also been reported from the Newania carbonatite complex.In addition, Ray et al. (2013) obtained ${ }^{40} \mathrm{Ar} /{ }^{39} \mathrm{Ar}$ age of $913 \pm 19 \mathrm{Ma}$ from phlogopite separate from ankeritic carbonatite vein and interpreted a thermal event in the area around $900 \mathrm{Ma}$. The episodes of alkaline magmatism and later metamorphic events have direct implication on the geodynamic evolution of the Indian subcontinent.

\section{Results}

\section{Petrography and mineral chemistry}

Nepheline syenite and syenite are the dominant rock types found in the Indian Proterozoic ARCs complexes. A summary of petrography including crystallinity, texture, and mineralogy are presented in Table 4. Here, we discuss the petrography of major rock types such as the nepheline syenite, syenite, carbonatite, and the associated mafic and high silica rock occurring in Proterozoic ARCs. Nepheline syenite and syenite are emplaced mainly as intrusive bodies and display coarse to medium grained crystallinity, and equigranular and hypidiomorphic texture. Nepheline syenite comprises nepheline (up to 30\%), plagioclase (up to $45 \%$ ), K-feldspar, clinopyroxene with minor biotite and amphibole (Table 4). Apatite, magnetite, titanite, ilmenite, calcite, zircon are present as accessory minerals. The nepheline syenite of the EGMB (e.g., Prakasam alkaline province) and surrounding country rocks (e.g., granodiorite gneiss) show prominent gneissic structures (Leelanandam et al., 2006). The K-feldspars in nepheline syenite of Sushina Hill, Purulia complex have $\mathrm{K}_{2} \mathrm{O}$ content of up to $16.59 \mathrm{wt} \%$ (Chakrabarty et al., 2016). However, albitic plagioclase is also present with $\mathrm{Na}_{2} \mathrm{O}$ up to 12.24 wt\% (Chakrabarty et al., 2016). ErrakondaChimakurti nepheline syenite contains albitic plagioclase (Vijaya 
Kumar et al., 2007). Pyroxene compositions of nepheline syenite are mostly reported from Purulia (Chakrabarty et al., 2016; Das et al., 2018). Basu and Bhattacharya (2014) noted an alkali trend $\left(\mathrm{Na}_{2} \mathrm{O}\right.$ : 10.97-12.96 wt\%) in aegirine augite to aegirine along with sympathetic variation with associated amphibole of alkaline rocks, which suggests that these minerals evolve from a sodic-calcic to sodic melt during magma differentiation under a changing oxidation environment. Nepheline syenite of Sushina Hill shows two generations of pyroxenes: early-formed pyroxenes (crystallized at $\sim 700^{\circ} \mathrm{C}$ ) have a diopsidic core surrounded by aegirine-rich rim, whereas late-formed pyroxenes (formed at $\sim 400^{\circ} \mathrm{C}$ ) are mainly aegirine-jadeitic in composition, product of late-stage deuteric event (Chakrabarty et al., 2016). Interestingly, Sushina Hill complex contains a primary eudialyte (Na-Ca-Fe silicate and rich in $\mathrm{Zr}$; Chakrabarty et al., 2016), which indicates that this is the only agpaitic nepheline syenite (i.e., peralkaline alkali feldspar nepheline syenite) of India that may have evolved from extensive fractionation of parental mafic magma under low oxygen fugacity (Mitchell and Chakrabarty, 2012). Chakrabarty et al. (2018) reported the lone occurrence of transitional agpaitic rocks in India, from the Sushina Hill. Pyroxene from Elchuru falls in between diopside-hedenbergite-aegirine augite solid solution (Upadhyay et al., 2006b).

Syenite is composed of K-feldspar (up to $85 \%$ ), quartz (up to $15 \%$ ), plagioclase (up to $60 \%$ ), clinopyroxene, biotite, and amphibole (Table 4). Syenite often shows hypidiomorphic texture with grain size varying from fine to medium to coarse (Rajesh, 2003). Sometimes pegmatitic texture is also visible (Upadhyay et al., 2006c; Vijaya Kumar et al., 2007). K-feldspar is generally coarse grained and shows mesoperthitic texture (Santosh et al., 2014). Pyroxene of syenite is mostly aegirine augite to aegirine (Basu and Bhattacharyya, 2014; Chakrabarty et al., 2016). Orthopyroxene is present in quartz monzosyenite and separated from feldspar by coronal garnet (Upadhyay and Raith, 2006a). Nephelinite/ijolite rocks contain nepheline, feldspar, clinopyroxene, amphibole, and display medium to porphyritic, hypidiomorphic and sieved texture (Table 4). High silica rock or alkali granite is porphyritic in nature and contains $\mathrm{K}$ feldspar (75-85\%), plagioclase (5-10\%), and clinopyroxene (5-10\%). Mafic rocks also exhibit variation in petrographic assemblages (Table 4). Alkali pyroxenite comprises mostly clinopyroxene (85\%) with minor biotite, olivine, and amphibole, whereas gabbro consists of plagioclase, clinopyroxene, and hornblende with accessory minerals like orthopyroxene, alkali feldspar, and opaque oxides.

Carbonatite contains mainly igneous carbonate minerals (> 50 modal \%) such ascalcite, dolomite, and ankerite etc. (Streckeisen, 1980; Woolley and Kempe, 1989). Along with dominant calciocarbonatite (with $>90 \%$ calcite) rocks, dolomitic carbonatite (or rauhaugite) and ferrocarbonatite are also reported from Proterozoic carbonatite complexes. Minor amount of accessory minerals such as apatite, pyrochlore, magnetite, barite, and pyroxene are also present in this carbonatite. Ferrocarbonatite mainly contains ankerite along with accessory phases of barite, apatite, and rare earth element (REE)bearing minerals, such as bastnaesite, baddeleyite, and britholite etc. Carbonatite is mainly medium to coarse grained characterized with xenomorphic, inequigranular/equigranular textures. Albitite and oligoclasite of Pakkanadu complex contain abundant sphene and allanite, which is uncommon in other carbonatite complexes (Ravindran, 1986).

Silicocarbonatite is reported only from the Samalpatti ( $n=5$; Viladkar and Subramanian, 1995; Kumar et al., 1998) and Hogenakal
( $n=1$; Natarajan et al., 1994) carbonatite complexes of Proterozoic age. Silicocarbonatite from Samalpatti contains 5-20\% silicate minerals such as pyroxene, phlogopite, amphibole, $\mathrm{K}$-feldspar, and albite (Viladkar and Subramanian, 1995). Viladkar and Subramanian (1995) provided textural evidence of a globule of silicate minerals surrounded by calcite matrix arguing in favour of liquid immiscibility. The Jokipatti complex is the only carbonatite complex in India that contains benstonite $\left[\mathrm{Ba}_{6} \mathrm{Ca}_{6} \mathrm{Mg}\left(\mathrm{CO}_{3}\right)_{13}\right]$ carbonatite, which also occurs in Murrun Massif carbonatite complex in Siberia (Vladykin et al., 2008). The ARCs formed during the second phase of alkaline magmatism (Fig. 2), having experienced amphibolite to granulite facies of metamorphism, contains higher proportion of biotite and amphibole. In places, biotite and amphibole replaces clinopyroxene, and at other places biotite and amphibole breaks down to form garnet and clinopyroxene during metamorphic event (Upadhyay et al., 2006a).

\section{Geochemistry}

The geochemical data (major oxides, trace elements, and radiogenic $\mathrm{Sr}-\mathrm{Nd}-\mathrm{Pb}$ isotope and stable $\mathrm{C}$ and $\mathrm{O}$ isotope compositions) of Proterozoic ARCs of India, compiled in this study, are discussed in detail below. All data were grouped into six major rock groups (see Table 2) namely nepheline syenite, syenite, nephelinite, mafic rock, high silica rock, and carbonatite.

\section{Major oxides compositions of Proterozoic ARCs and associated rocks}

As mentioned earlier, rocks of Proterozoic ARCs are grouped into six categories (Table 2) mainly based on their major oxides compositions presented in Figs. 3-5. The total alkali versus silica (TAS diagram; Cox et al., 1979) diagram confirms that majority of alkaline rocks are nepheline syenite, syenite, and nephelinite (Fig. 3a). However, a part of mafic and high silica rock is subalkaline. Ternary $\mathrm{CaO}-\mathrm{MgO}-\mathrm{FeO}+\mathrm{Fe}_{2} \mathrm{O}_{3}+\mathrm{MnO}$ diagram (Woolley and Kempe, 1989) shows that calciocarbonatite and dolomitic carbonatite constitute the major rock types in Proterozoic carbonatite complexes (Fig. 3b, $n=149$ ). The $\mathrm{SiO}_{2}$ content of alkaline and associated rocks varies from 40 to $74 \mathrm{wt} \%$; carbonatites have very low silica content in the range $0.01-27 \mathrm{wt} \%$. Few pyroxenites of Hogenakal carbonatite complex contain low silica $\left(\mathrm{SiO}_{2}: 22-26 \mathrm{wt} \%\right)$ and are rare in Indian Proterozoic ARCs (Natarajan et al., 1994). A negative correlation is observed between $\mathrm{TiO}_{2}, \mathrm{Al}_{2} \mathrm{O}_{3}, \mathrm{Fe}_{2} \mathrm{O}_{3}$, and $\mathrm{CaO}$ versus silica content mostly for the syenite, nepheline syenite and high silica rock (Fig. 4). However, a weak correlation is observed for mafic and nephelinite rocks. Nepheline syenites have a narrow range of $\mathrm{SiO}_{2}$ content between 50 to $60 \mathrm{wt} \%$, but other major oxides such as $\mathrm{TiO}_{2}, \mathrm{Fe}_{2} \mathrm{O}_{3}, \mathrm{Na}_{2} \mathrm{O}$, and $\mathrm{K}_{2} \mathrm{O}$ show notable variations, whereas $\mathrm{Al}_{2} \mathrm{O}_{3}(15-27$ wt $\%), \mathrm{MgO}$ (0.01-1.79 wt \%) and $\mathrm{P}_{2} \mathrm{O}_{5}(0.01-0.42 \mathrm{wt} \%)$ contents vary comparatively less (Fig. 4). Nephelinite typically contains less silica ( $\mathrm{SiO}_{2}: 40-50 \mathrm{wt} \%$ ) compared to nepheline syenite and syenite. Although no trend is present in nephelinite, overall major oxides concentrations are comparable with syenite and nepheline syenite except for $\mathrm{MgO}, \mathrm{CaO}$ and $\mathrm{P}_{2} \mathrm{O}_{5}$, which are higher in nephelinite. Mafic rock contains higher amount of $\mathrm{MgO}$ (up to $22.6 \mathrm{wt} \%$ in olivine clinopyroxenite; Vijaya Kumar et al., 2007), $\mathrm{CaO}$ (up to $38 \mathrm{wt} \%$ in carbonate-mica pyroxenite; Natarajan et al., 1994), and low $\mathrm{Na}_{2} \mathrm{O}$, $\mathrm{K}_{2} \mathrm{O}$ and $\mathrm{P}_{2} \mathrm{O}_{5}$ compared to other rock categories (Fig. 4). High silica 
Table 4. Summary of petrographic characteristics of the Proterozoic alkaline rocks of India.

\begin{tabular}{|c|c|c|c|c|}
\hline Complex location & Crystallinity & Texture & Mineralogy & References \\
\hline $\begin{array}{l}\text { Newania, } \\
\text { Rajasthan }\end{array}$ & $\begin{array}{l}\text { Dolomite and Ankerite } \\
\text { carbonatite: Medium to } \\
\text { coarse-grained }(1,2,3)\end{array}$ & $\begin{array}{l}\text { Cumulate texture } \\
\text { and flow bands ( } 3 \text { ) }\end{array}$ & $\begin{array}{l}\text { Dolomitic carbonatite: dolomite or ankerite, siderite, } \\
\text { and accessory magnesite and calcite, apatite }(1,2,3) \text {; } \\
\text { Ankerite carbonatite: dolomite or ankerite }(1,2,3) \text {; }\end{array}$ & $\begin{array}{l}\text { 1. Viladkar and Wimmenauer } \\
\text { (1986); 2. Schleicher et al. } \\
\text { (1997); 3. Ray et al. (2013) }\end{array}$ \\
\hline
\end{tabular}

Purulia,

West Bengal

Chhatabar-

Lodhajhari-

Baradangua,

Odisha

Rairakhol,

Odisha

Kamakhya-

nagar, Odisha

Khariar,

Odisha

Koraput,

Odisha

Kunavaram,

Andhra Pradesh

Vikurthi,

Andhra Pradesh

Coarse to medium

grained (2)

Kotappakonda,

Andhra Pradesh

Coarse to medium grained (2)

Jojuru,

Andhra Pradesh

Elchuru,

Andhra Pradesh

Medium grained to porphyritic (2)

Settupalle,

Andhra Pradesh

Purimetla,

Andhra Pradesh

Errakonda, Andhra Pradesh

Chanduluru, Andhra Pradesh

Medium to coarse grained (2)

Coarse grained $(1,2)$

Medium-grained (1)

Fine to coarse grained (2)

Podili,

Coarse-grained (2)
Carbonatite: mosaic texture; alkali pyroxenite: hypidiomorphic texture (1) accessory minerals: apatite, magnetite, phlogopite, magnesio-arvfedsonite, and zircon. pyrochlore, columbite, amphibole, pyroxene, monazite $(1,2,3)$

Nepheline syenite: potassium feldspar, albite (30-45\%), aegirine, nepheline (20-30\%), clinopyroxene; syenite: K-feldspars (50-60\%), quartz (<5\%), albite; carbonatite: calcite $(\sim 90 \%)$, apatite; alkali pyroxenite: clinopyroxene $(85 \%)$, calcite, biotite, apatite, amphibole $(1,2,3,4,5)$

Nepheline syenite: microcline, nepheline, sodic plagioclase (1)

1. Chakrabarty and Sen, (2010); 2. Mitchell and Chakrabarty (2012);

3. Basuand Bhattacharyya (2014); 4. Chakrabarty et al. (2016); 5. Das et al. (2018)

1. Sheikh et al. (2017)

Nepheline syenite: Calcic amphibole and pyroxene, phlogopite rich biotite, alkali feldspar, nepheline and plagioclase $(1,2)$

Nepheline syenite: Alkali feldspar, plagioclase, nepheline, biotite, amphibole (1)

Nepheline syenite: nepheline, clinopyroxene, feldspar, 1. Leelanandam et al. (2006); amphibole, biotite; syenite: perthitic microcline, nepheline; ijolite: nepheline, feldspar, clinopyroxene, amphibole $(1,2)$

Equigranular (1)

Nepheline syenite and syenite: K-feldspar, plagioclase, 1. Nanda et al. (2008); biotite, hornblende, ilmenite and garnet (1)

2. Hippe et al. (2016)

Nepheline syenite: alkali feldspar (microcline), nepheline, plagioclase, calcite; Syenite:

1. Upadhyay and Raith, perthitic alkali feldspar, amphibole and/or biotite;

Nepheline monzonite: plagioclase, biotite with minor alkali feldspar, calcite and zircon (1)

Equigranularhypidiomorphic (2)

Syenite: perthitic microcline, pyroxene, hornblende, biotite, quartz, plagioclase $(1,2)$ (2006b)

Equigranular hypidiomorphic (2)

Nepheline syenite: perthitic microcline, pyroxene, hornblende, biotite, plagioclase, quartz $(1,2)$

Quartz-bearing monzosyenite: plagioclase and alkali feldspar, clinopyroxene, orthopyroxene, ilmenite, garnet, biotite, quartz (1)

Hypidiomorphic and sieve-like intergrowth (2)

Ijolite: nepheline, clinopyroxene and amphibole; Shonkinite: megacrysts of clinopyroxene; Nepheline diorite: clinopyroxene, plagioclase and biotite. Nepheline syenite: alkali feldspar, nepheline, biotite, clinopyroxene and amphibole $(1,2)$

Equigranular hypidiomorphic (2)

Syenite: microcline perthite, microcline, plagioclase, quartz, amphibole, biotite $(1,2)$

Hypidiomorphic and seldom porphyroclastic $(1,2)$

Shonkinite: Orthoclase perthite, amphibole, quartz, plagioclase, biotite $(1,2)$

Hypidiomorphic texture (1)

Ferrosyenite: megacrysts of amphibole, alkali feldspar (1)

Hypidiomorphic (2)

Syenite: perthitic orthoclase, amphibole, quartz, plagioclase, biotite, hornblende, K-feldspar perthite (2)

1. Sridhar et al. (2018);

2. Madhavan, et al. (1995)

1. Sridhar et al. (2018);

2. Madhavan et al. (1995)

1. Upadhyay and Raith(2006)

1. Sridhar et al. (2018); 2. Upadhyay et al. (2006b)

1. Bhattacharya and Basei (2018)

1. Ranjan et al. (2018)

Andhra Pradesh

Equigranular

Syenite: K-feldspar, hornblende, biotite, hypidiomorphic (2) plagioclase $(1,2)$

1. Sridhar et al. (2018);

2. Leelanandam (1989)

1. Sridhar et al. (2018);

2. Ratnakar and

Leelanandam (1986)

1. Kumar et al. (2007)

1. Sridhar et al. (2018);

2. Sharma and Ratnakar (2000)

1. Sridhar et al. (2018);

2. Sai (2017) 
Table 4. Contd....

\begin{tabular}{|c|c|c|c|c|}
\hline Complex location & Crystallinity & Texture & Mineralogy & References \\
\hline $\begin{array}{l}\text { Uppalapadu, } \\
\text { Andhra Pradesh }\end{array}$ & $\begin{array}{l}\text { Medium to Coarse } \\
\text { grained (2); porphyritic }\end{array}$ & $\begin{array}{l}\text { Equigranular } \\
\text { hypidiomorphic and } \\
\text { pegmatitic texture (2) }\end{array}$ & $\begin{array}{l}\text { Nepheline syenite: nepheline, K-feldspar perthite, } \\
\text { quartz, amphibole, biotite, plagioclase }(1,2)\end{array}$ & $\begin{array}{l}\text { 1. Sridhar et al. (2018); } \\
\text { 2. Kumar et al. (2007) }\end{array}$ \\
\hline $\begin{array}{l}\text { Racherla, } \\
\text { Andhra Pradesh }\end{array}$ & $\begin{array}{l}\text { Coarse to medium } \\
\text { grained (1) }\end{array}$ & $\begin{array}{l}\text { Equigranular and } \\
\text { hypidiomorphic } \\
\text { textures (1) }\end{array}$ & $\begin{array}{l}\text { Alkali syenite: orthoclase-perthite and riebeckite, } \\
\text { apatite, biotite, Fe-Ti oxides (1) }\end{array}$ & 1. Rao et al. (2012) \\
\hline $\begin{array}{l}\text { Dancherla } \\
\text { alkaline complex, } \\
\text { Andhra Pradesh }\end{array}$ & $\begin{array}{l}\text { All type of grain size } \\
\text { distribution: coarse to } \\
\text { fine grained, porphyritic } \\
\text { and pegmatoidal } \\
\text { varieties (1) }\end{array}$ & $\begin{array}{l}\text { Porphyritic } \\
\text { texture (1) }\end{array}$ & $\begin{array}{l}\text { Syenite: Aegirine, microcline perthite, orthoclase } \\
\text { and plagioclase (1) }\end{array}$ & 1. Suresh et al. (2010) \\
\hline $\begin{array}{l}\text { Pulikonda } \\
\text { alkaline complex, } \\
\text { Andhra Pradesh }\end{array}$ & $\begin{array}{l}\text { Medium to fine } \\
\text { grained (1) }\end{array}$ & & $\begin{array}{l}\text { Syenite: Aegirine/aegirine-augite, microcline } \\
\text { perthite, plagioclase feldspar } \pm \text { hornblende } \\
\text { and biotite (1) }\end{array}$ & 1. Suresh et al. (2010) \\
\hline $\begin{array}{l}\text { Elagiri, } \\
\text { Tamil Nadu }\end{array}$ & $\begin{array}{l}\text { Syenite: phanero- } \\
\text { crystalline, pegmatoidal } \\
\text { to medium grained; } \\
\text { Gabbro: coarse grained, } \\
\text { phenerocrystalline (1) }\end{array}$ & & $\begin{array}{l}\text { Nepheline syenite: pyroxene, amphibole, alkali- } \\
\text { feldspar; syenite: albite }(3-31 \%) \text {, amphibole } \\
(3-11 \%) \text {, potassium feldspar }(62-68 \%) \text {, nepheline, } \\
\text { biotite }(0.5-7 \%) \text {; Gabbro: plagioclase, clinopyroxene } \\
\text { and hornblende with accessory minerals like } \\
\text { orthopyroxene, alkali feldspar, opaque oxides }(1,2)\end{array}$ & $\begin{array}{l}\text { 1. Mukhopadhyay et al. } \\
\text { (2011a); 2. Renjith et al. } \\
\text { (2014) }\end{array}$ \\
\hline $\begin{array}{l}\text { Sevattur, } \\
\text { Tamil Nadu }\end{array}$ & $\begin{array}{l}\text { Syenite: medium to } \\
\text { coarse grained }(2)\end{array}$ & $\begin{array}{l}\text { Syenite: hypidio- } \\
\text { morphic texture }(2)\end{array}$ & $\begin{array}{l}\text { Carbonatite: sovite and beforsite, with apatite, } \\
\text { magnetite, and iron rich phlogopite as accessory } \\
\text { minerals; Pyroxenite: clinopyroxene, with minor } \\
\text { amounts (about } 5 \% \text { ) of biotite, olivine; Syenite: } \\
\text { K-feldspar (microcline or perthite), sodic plagioclase, } \\
\text { clinopyroxene and occasional hornblende }(1,2,3,4)\end{array}$ & $\begin{array}{l}\text { 1. Kumar and Gopalan } \\
\text { (1991); 2. Miyazaki et al. } \\
\text { (2000); 3. Kumar et al. } \\
\text { (1998); 4. Ackerman et al. } \\
\text { (2017) }\end{array}$ \\
\hline $\begin{array}{l}\text { Sundamalai, } \\
\text { Tamil Nadu }\end{array}$ & $\begin{array}{l}\text { Medium to coarse } \\
\text { grained (1) }\end{array}$ & $\begin{array}{l}\text { Hypidiomorphic } \\
\text { in equigranular } \\
\text { texture }(1)\end{array}$ & $\begin{array}{l}\text { Syenite: plagioclase }(20-60 \%) \text {, amphibole } \\
(10-25 \%), \text { K-feldspar }(5-20 \%) \text {, and quartz } \\
(5-10 \%)(1)\end{array}$ & 1. Renjith et al. (2016a) \\
\hline $\begin{array}{l}\text { Samalpatti, } \\
\text { Tamil Nadu }\end{array}$ & $\begin{array}{l}\text { Gabbro: coarse } \\
\text { grained ( } 2)\end{array}$ & Phaneritic texture (2) & $\begin{array}{l}\text { Carbonatite: calcite, minor dolomite; pyroxenite: } \\
\text { pyroxene, biotite, apatite and Fe-Ti oxides; gabbro: } \\
\text { K-feldspar, pyroxene, biotite, Fe-Ti oxides, } \\
\text { plagioclase and apatite; monzonite: plagioclase, } \\
\text { K-feldspar }(1,2)\end{array}$ & $\begin{array}{l}\text { 1. Moralev et al. (1975); } \\
\text { 2. Ackerman et al. (2017) }\end{array}$ \\
\hline $\begin{array}{l}\text { Jokipatti, } \\
\text { Tamil Nadu }\end{array}$ & $\begin{array}{l}\text { Medium to coarse } \\
\text { grained (1) }\end{array}$ & & $\begin{array}{l}\text { Carbonatite: Calcite, dolomite, ankerite, mica, } \\
\text { monazite, riebeckite, ilmenite, benstonite, bastnaesite, } \\
\text { pyrochlore, thorite, aegirine barite (1) }\end{array}$ & 1. Schleicher et al. (1998) \\
\hline $\begin{array}{l}\text { Hogenakal, } \\
\text { Tamil Nadu }\end{array}$ & $\begin{array}{l}\text { Carbonatite: medium } \\
\text { to coarse grained; } \\
\text { Syenite: medium to } \\
\text { coarse grained (1); } \\
\text { pyroxenite: medium } \\
\text { to coarse grained (2) }\end{array}$ & $\begin{array}{l}\text { Carbonatite: } \\
\text { xenomorphic, } \\
\text { inequigranular or } \\
\text { equigranular; } \\
\text { seriate and } \\
\text { porphyritic } \\
\text { textures also } \\
\text { occur (1); } \\
\text { pyroxenite: } \\
\text { equigranular (2) }\end{array}$ & $\begin{array}{l}\text { Carbonatite: calcite }(50-70 \%) \text {, apatite, minor } \\
\text { phlogopite and pyroxene; Pyroxenite: salite }(90 \%) \text {, } \\
\text { phlogopite }(5 \%) \text {, apatite, calcite, hornblende; } \\
\text { Syenite: orthoclase }(95 \%) \text {, pyroxene, apatite, calcite, } \\
\text { sphene, phlogopite, magnetite (1). }\end{array}$ & $\begin{array}{l}\text { 1. Natarajan et al. (1994); } \\
\text { 2. Kumar et al. (1998) }\end{array}$ \\
\hline $\begin{array}{l}\text { Pakkanadu, } \\
\text { Tamil Nadu }\end{array}$ & $\begin{array}{l}\text { Fine to coarse } \\
\text { grained sovite (2) }\end{array}$ & $\begin{array}{l}\text { Granular texture } \\
\text { with well-develop- } \\
\text { ed rhombic } \\
\text { cleavages (2) }\end{array}$ & $\begin{array}{l}\text { Carbonatite: Calcite, magnetite, ankerite, apatite, } \\
\text { sphene and monazitetitanite, biotite, phlogopite, } \\
\text { allanite }(1,2)\end{array}$ & $\begin{array}{l}\text { 1. Schleicher et al. (1998); } \\
\text { 2. Pandit et al. (2002) }\end{array}$ \\
\hline $\begin{array}{l}\text { Sivamalai, } \\
\text { Tamil Nadu }\end{array}$ & $\begin{array}{l}\text { Coarse-grained } \\
\text { pegmatitic to fine- } \\
\text { grained (1) }\end{array}$ & $\begin{array}{l}\text { Granoblastic } \\
\text { texture (1) }\end{array}$ & $\begin{array}{l}\text { Nepheline syenite: perthitic alkali feldspar and } \\
\text { nepheline with minor plagioclase, opaques, } \\
\text { amphibole, clinopyroxene and biotite }(1)\end{array}$ & 1. Upadhyay et al. (2006c) \\
\hline $\begin{array}{l}\text { Korangani, } \\
\text { Tamil Nadu }\end{array}$ & $\begin{array}{l}\text { Medium to coarse } \\
\text { grained (1) }\end{array}$ & Cumulate texture (1) & Syenite: Quartz, orthoclase, calcite and perthite (1) & 1. Renjith et al. (2016b) \\
\hline $\begin{array}{l}\text { Kambammettu, } \\
\text { Tamil Nadu }\end{array}$ & $\begin{array}{l}\text { Carbonatite: fine } \\
\text { to coarse grained, } \\
\text { pegmatoidal and }\end{array}$ & $\begin{array}{l}\text { Syenite: allotrio- } \\
\text { morphic texture (1) }\end{array}$ & $\begin{array}{l}\text { Carbonatite: calcite, dolomite, magnetite, apatite } \\
\text { olivine, clinopyroxene, phlogopite, strontianite and } \\
\text { barite, monazite, rarely zircon; Syenite: K-feldspar, }\end{array}$ & 1. Renjith et al. (2016b) \\
\hline
\end{tabular}


Table 4. Contd....

\begin{tabular}{|c|c|c|c|c|}
\hline Complex location & Crystallinity & Texture & Mineralogy & References \\
\hline & $\begin{array}{l}\text { coarse grained } \\
\text { rhombohedral } \\
\text { calcite; Syenite: } \\
\text { medium grained (1) }\end{array}$ & & $\begin{array}{l}\text { quartz, plagioclase, titanite, magnetite, zircon, } \\
\text { and apatite (1) }\end{array}$ & \\
\hline $\begin{array}{l}\text { Munnar, } \\
\text { Tamil Nadu }\end{array}$ & $\begin{array}{l}\text { Syenite: coarse- } \\
\text { grained; Carbonatite: } \\
\text { coarse grained (1) }\end{array}$ & $\begin{array}{l}\text { Carbonatite: } \\
\text { Interlocking texture } \\
\text { and polysynthetic } \\
\text { twinning (1) }\end{array}$ & $\begin{array}{l}\text { Syenite: K-feldspar, augite, aegirine augite, } \\
\text { plagioclase, alkali amphibole, biotite, apatite, } \\
\text { sphene, zircon; Carbonatite: calcite, pyroxene, } \\
\text { apatite, magnetite, dolomite, aegirine, augite, } \\
\text { rarely phlogopite, biotite and minor albite (1) }\end{array}$ & 1. Nair et al. (1984) \\
\hline $\begin{array}{l}\text { Marunthurkota, } \\
\text { Tamil Nadu }\end{array}$ & $\begin{array}{l}\text { Medium to coarse- } \\
\text { grained }\end{array}$ & $\begin{array}{l}\text { Hypidiomorphic } \\
\text { texture (1) }\end{array}$ & $\begin{array}{l}\text { Syenite: K-feldspar ( } 70-85 \%) \text {, quartz }(5-15 \%) \text {, } \\
\text { plagioclase, augite and hornblende (1) }\end{array}$ & 1. Sreejith and $\operatorname{Kumar}(2009)$ \\
\hline $\begin{array}{l}\text { Puttetti, } \\
\text { Tamil Nadu }\end{array}$ & $\begin{array}{l}\text { Syenite and pyroxenite: } \\
\text { medium- to coarse- } \\
\text { grained (1) }\end{array}$ & $\begin{array}{l}\text { Phaneritic } \\
\text { texture (1) }\end{array}$ & $\begin{array}{l}\text { Syenite: feldspar and pyroxene with minor } \\
\text { amphibole and biotite; Pyroxenite: hedenbergite or } \\
\text { augite, perthitic K-feldspar, amphibole, phlogopite, } \\
\text { and biotite (1) }\end{array}$ & 1. Rajesh (2003) \\
\hline $\begin{array}{l}\text { Peralimala, } \\
\text { Kerala }\end{array}$ & Coarse grained (1) & & $\begin{array}{l}\text { Alkali granite: K-feldspar ( } 75-85 \%) \text {, plagioclase, } \\
(5-10 \%) \text {, and clinopyroxene }(5-10 \%)(1)\end{array}$ & 1. Santosh et al. (2014) \\
\hline $\begin{array}{l}\text { Angadimogar, } \\
\text { Kerala }\end{array}$ & $\begin{array}{l}\text { Medium to coarse- } \\
\text { grained (1) }\end{array}$ & & $\begin{array}{l}\text { Syenite: K-feldspar }(30-40 \%) \text {, plagioclase }(25-35 \%) \text {, } \\
\text { calcic amphibole (ferroedenite) }(10-15 \%) \text {, quartz } \\
(5-10 \%) \text {, and biotite }(5-10 \%)(1)\end{array}$ & 1. Santosh et al. (2014) \\
\hline
\end{tabular}
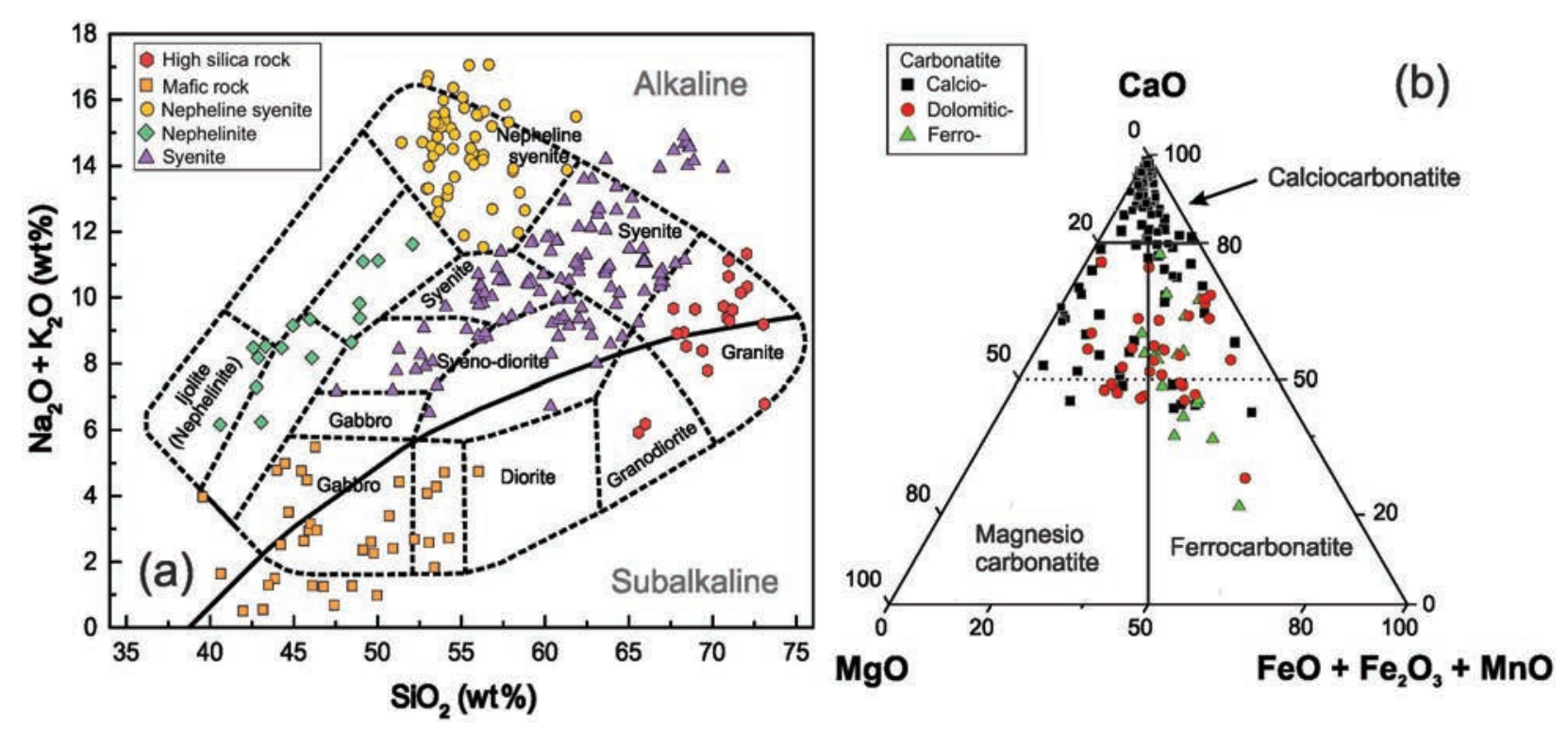

Figure 3.Chemical classification of Proterozoic ARCs. (a) Total Alkali Silica (TAS; Cox et al., 1979) diagram for plutonic igneous rocks show different alkaline rock types along with associated mafic and high silica rocks. Nephelinite is volcanic equivalent of ijolite. (b) Ternary $\mathrm{CaO}-\mathrm{MgO}-\mathrm{FeO}_{+} \mathrm{Fe}_{2} \mathrm{O}_{3}+\mathrm{MnO}$ diagram (Woolley and Kempe, 1989) for Proterozoic Indian carbonatites.

rocks, mostly alkali granite, follows similar major oxides trend observed in syenite (Fig. 4). In general, a negative correlation of $\mathrm{CaO}$, $\mathrm{Fe}_{2} \mathrm{O}_{3}$, and $\mathrm{MgO}$ with increasing $\mathrm{SiO}_{2}$ suggests fractionation of mafic minerals such as clinopyroxene and amphibole. Negative correlation of $\mathrm{TiO}_{2}$ with $\mathrm{SiO}_{2}$ along with positive correlation between $\mathrm{TiO}_{2}$ and $\mathrm{Fe}_{2} \mathrm{O}_{3}$ (not shown) suggest titanite fractionation. Moreover, a positive correlation between $\mathrm{P}_{2} \mathrm{O}_{5}$ and $\mathrm{CaO}$ (not shown) reveals apatite fractionation to have played a role in magma evolution. No correlation of $\mathrm{Na}_{2} \mathrm{O}, \mathrm{K}_{2} \mathrm{O}$, and $\mathrm{Al}_{2} \mathrm{O}_{3}$ with increasing $\mathrm{SiO}_{2}$ content indicates negligible plagioclase, orthoclase feldspar, and biotite fractionation.
These results show that crystal fraction has played an important role in the formation of Proterozoic alkaline rocks.

Bulk major oxides composition of Proterozoic carbonatite namely calciocarbonatite $(n=98)$, dolomitic carbonatite $(n=32)$, ferrocarbonatite $(n=19)$, silicocarbonatite $(n=30)$, and benstonite carbonatite $(n=4)$, compiled in study from various sources (Phadke and Jhingran, 1968; Subramanian et al., 1978; Sukheswala and Viladkar, 1978; Nair et al., 1984; Viladkar and Wimmenauer, 1986; Natarajan et al., 1994; Viladkar and Subramanian, 1995; Kumar et al., 1998; Pandit et al., 1998, 2002; Schleicher et al., 1998; Viladkar, 


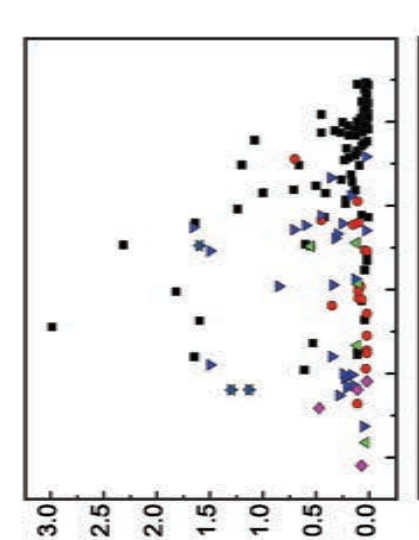

$(\% \backslash M)^{z} \mathrm{O} \perp$
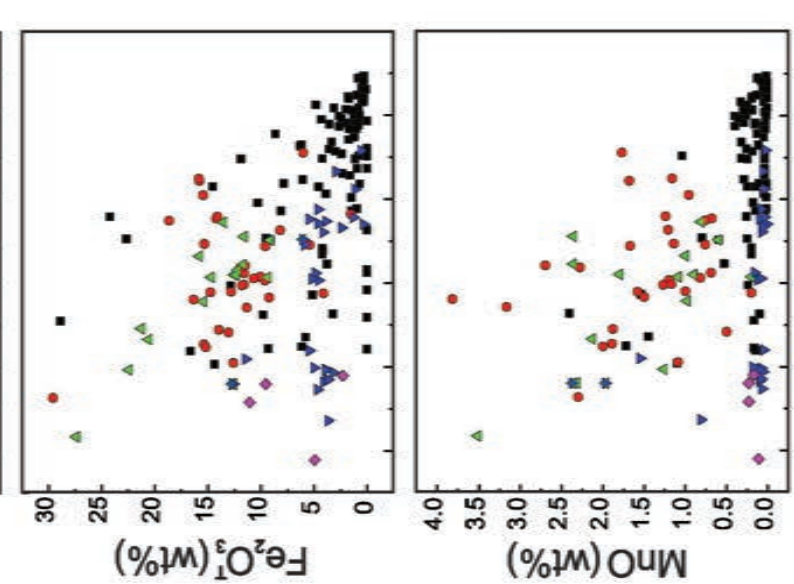

(\%\M) OuW

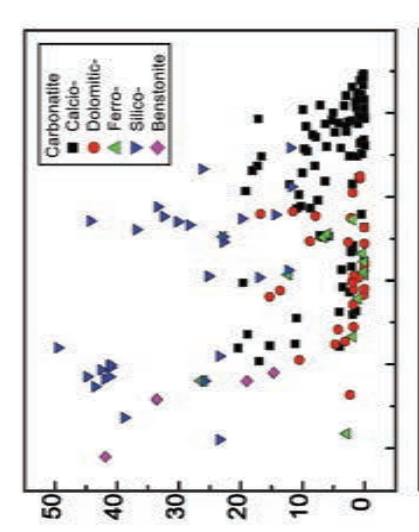

$(\% \nmid M)^{2} \mathrm{O} ! S$

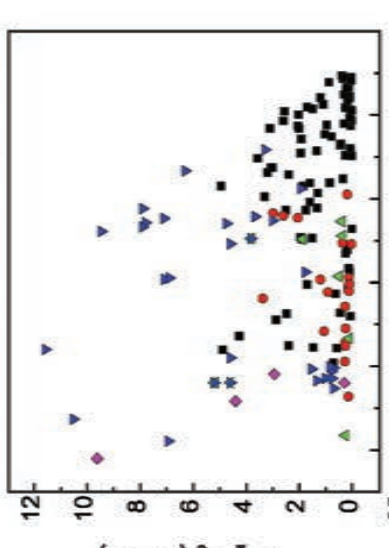

$(\% \nmid M)^{2} O^{z} \mid \forall$
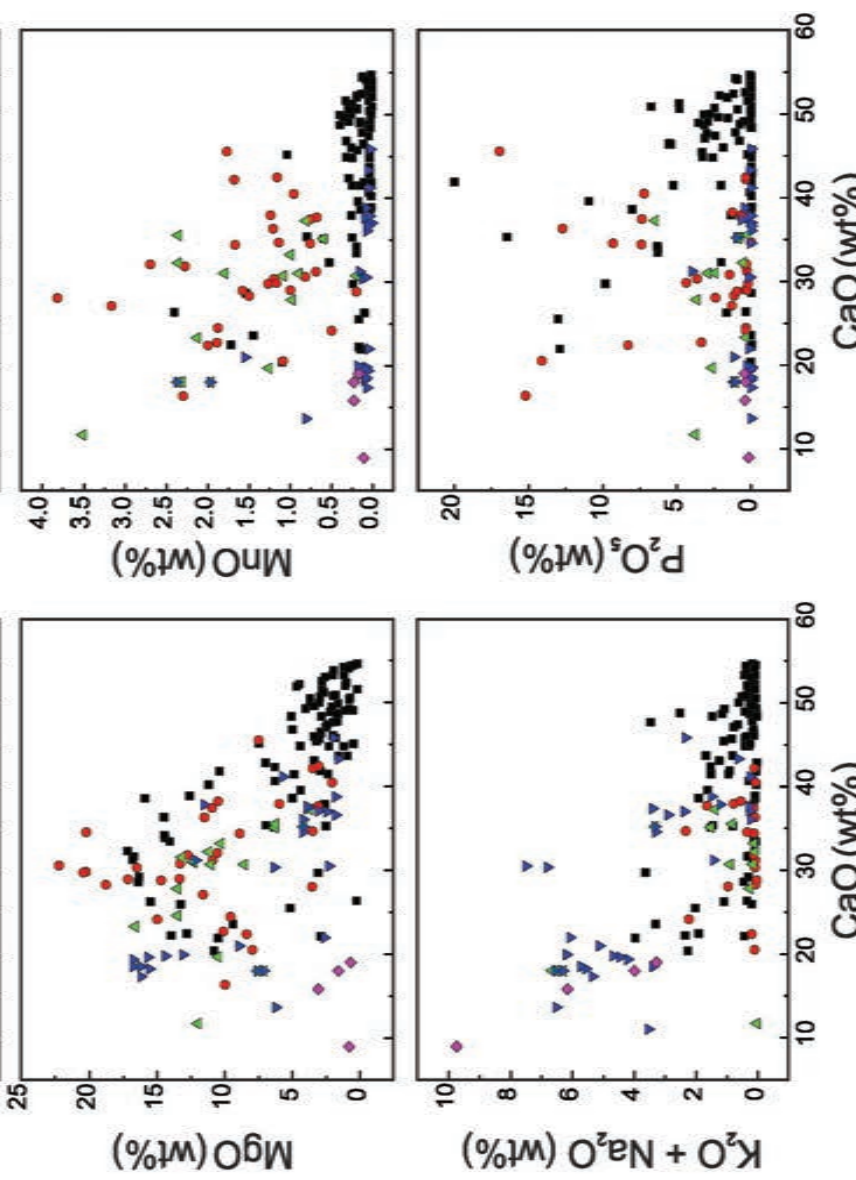

$(\% \not M)^{s} O^{z} d$

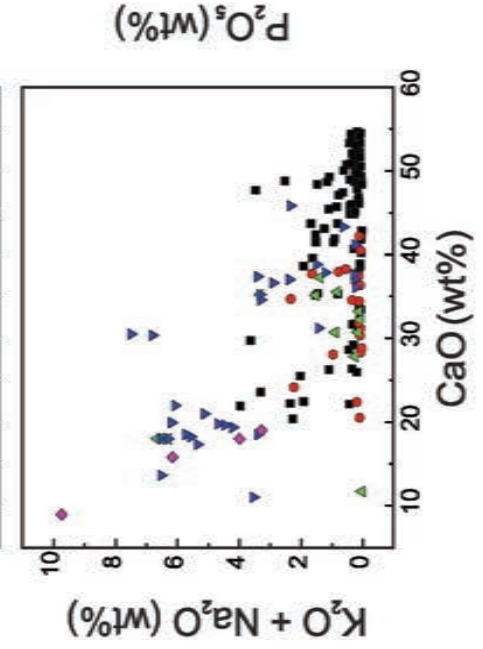

है

ํำ

s.

(2)

政

ㅇำ

응

총

เั้

)

is

ริ

ํํำ

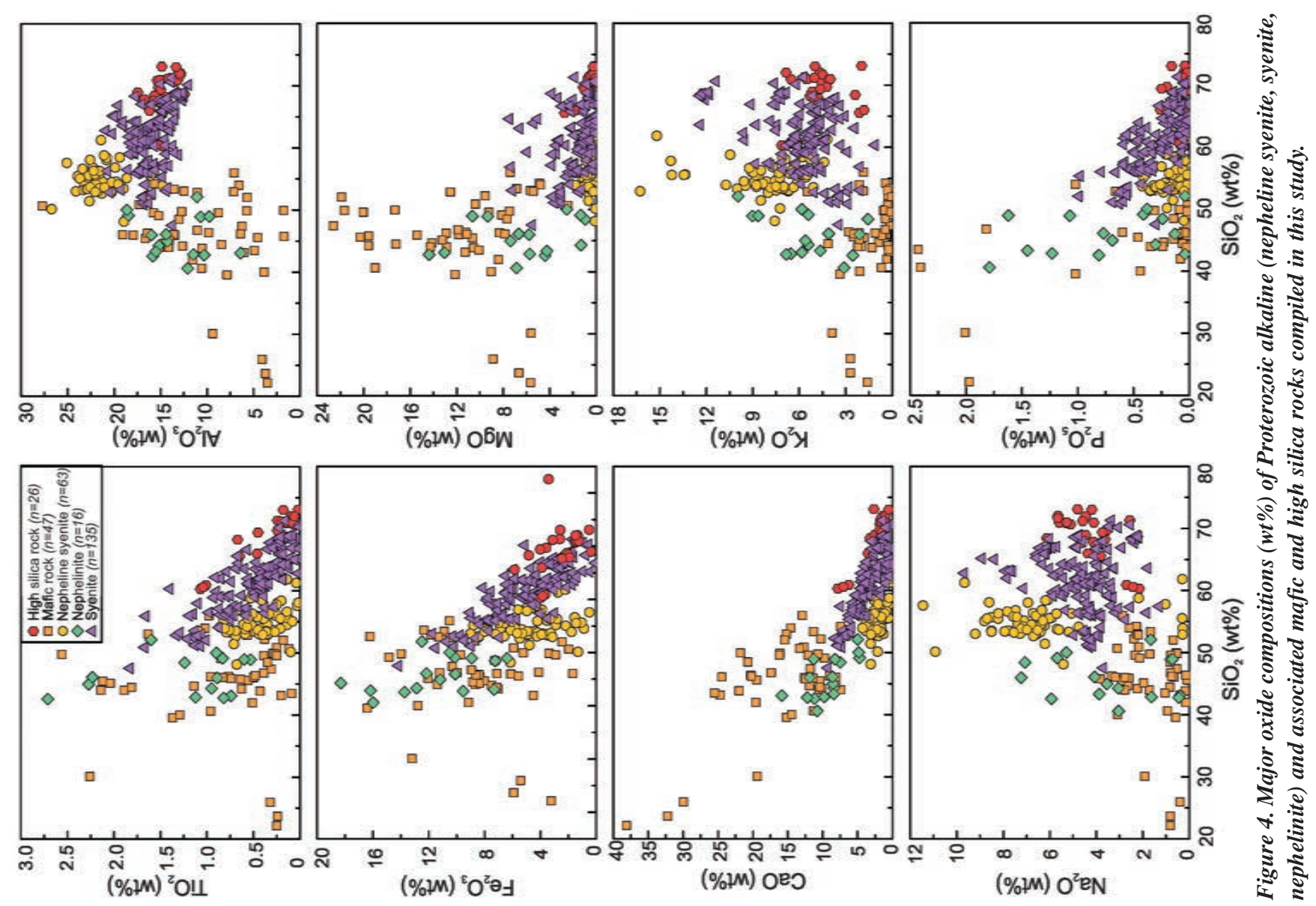


1998; Catlos et al., 2008; Vladykin et al., 2008; Chakrabarty and Sen, 2010; Ray et al., 2013; Renjith et al., 2016b; Ackerman et al., 2017), are presented in Fig. 5. Majority of calciocarbonatite shows a narrow $\mathrm{CaO}$ range of 35-55 wt\%, although abundances as low as 14 wt $\%$ have also been reported. The $\mathrm{CaO}$ content of dolomitic carbonatite and ferrocarbonatite vary in ranges 16-46 wt\% and 12$37 \mathrm{wt} \%$, respectively. Poor negative correlations of $\mathrm{SiO}_{2}, \mathrm{Al}_{2} \mathrm{O}_{3}$, $\mathrm{Fe}_{2} \mathrm{O}_{3}, \mathrm{MgO}$, and $\mathrm{K}_{2} \mathrm{O}+\mathrm{Na}_{2} \mathrm{O}$ vs. $\mathrm{CaO}$ are observed in the calciocarbonatite. Ferrocarbonatite reveals steep negative correlation of $\mathrm{Fe}_{2} \mathrm{O}_{3}(6-27 \mathrm{wt} \%)$ vs. $\mathrm{MgO}(4-17 \mathrm{wt} \%)$ and $\mathrm{MnO}(0.2-3.5 \mathrm{wt} \%)$ vs. $\mathrm{CaO}$. These have similar $\mathrm{SiO}_{2}, \mathrm{TiO}_{2}, \mathrm{Al}_{2} \mathrm{O}_{3}, \mathrm{P}_{2} \mathrm{O}_{5}$, and $\mathrm{K}_{2} \mathrm{O}+\mathrm{Na}_{2} \mathrm{O}$ abundances as in the dolomitic carbonatite. The presence of $>20 \%$ $\mathrm{SiO}_{2}$ content is the criterion (Srivastava, 1993) taken for defining silicocarbonatite. The $\mathrm{CaO}$ and $\mathrm{SiO}_{2}$ contents of silicocarbonatite varies in the ranges $11-46 \mathrm{wt} \%$ and $12-50 \mathrm{wt} \%$, respectively. Benstonite carbonatite is characterized with high $\mathrm{BaO}$ (9-26 wt $\%$ ) and $\mathrm{SiO}_{2}(15-42 \mathrm{wt} \%)$ and moderate $\mathrm{CaO}(9-19 \mathrm{wt} \%)$. It also contains variable amounts of $\mathrm{Al}_{2} \mathrm{O}_{3}(0.3-9 \mathrm{wt} \%), \mathrm{Fe}_{2} \mathrm{O}_{3}(2-11 \mathrm{wt} \%)$, and $\mathrm{K}_{2} \mathrm{O}+\mathrm{Na}_{2} \mathrm{O}(3.2-9.7 \mathrm{wt} \%)$, and $\mathrm{MgO}<3.1 \mathrm{wt} \%$. As suggested in the earlier studies, the variation in major oxides composition of carbonatite can be explained by crystal fractionation of calcite, dolomite, ankerite, pyroxene, apatite, magnetite, mica, and pyrochlore etc. during magma crystallization.

\section{Trace elements (including REEs) concentrations}

Primitive-mantle normalized (Sun and McDonough, 1989) trace element patterns of the Proterozoic alkaline rocks namely nepheline syenite $(n=45)$, nephelinite $(n=9)$, syenite $(n=146)$, as well as the associated mafic rock $(n=62)$ and high silica rock $(n=19)$ are presented in Fig. 6. The nepheline syenite shows strong depletion in $\mathrm{P}, \mathrm{Zr}$ and $\mathrm{Ti}$, moderate depletion in $\mathrm{Th}$ and $\mathrm{Ta}$, and moderate enrichment of K (Fig. 6a). Syenite shows characteristic depletion in $\mathrm{Nb}, \mathrm{Ta}, \mathrm{La}, \mathrm{Ce}$ and $\mathrm{P}$, moderate depletion in $\mathrm{Zr}$ and Ti, and enrichment of Ba (Fig. 6b). The pattern of nephelinite (Fig. 6c), though similar to those of other alkaline rocks, display a comparatively restricted range of abundances. These alkaline rocks show significant enrichment in large ion lithophile elements (LILE) compared to the high field strength elements (HFSE), similar to that found in global alkaline rocks. Trace element patterns of high silica rock show characteristic depletion of Nb, Ta, Zr, and Ti (Fig. 6d). Patterns for the mafic rock exhibit wider variability showing no specific pattern other than a minor depletion of $\mathrm{Zr}$ and Ti (Fig. 6e). Patterns of Proterozoic carbonatite ( $n=166$ ) exhibit distinct depletions in K, Zr, Hf, and Ti (Fig. 6f), which is also a characteristic signature of carbonatite world-wide (Woolley and Kempe, 1989; Chandra et al., 2018). Depletion of Zr and $\mathrm{Ti}$ is common in all the rocks, except in nephelinite. Generally, limited trace elements data, that is concentrations of $\mathrm{Ba}, \mathrm{Nb}, \mathrm{La}, \mathrm{Ce}$, $\mathrm{Sr}, \mathrm{Zr}$ and $\mathrm{Y}$, have been mostly reported for the Indian Proterozoic carbonatite (Fig. 6f). Based on our compiled data, abundances of REE, Sr, and LILE in the carbonatiteis about 10-100 times that of the other rock groups discussed here.

Chondrite-normalized (Sun and McDonough, 1989) rare earth element (REE) patterns of Proterozoic ARCs are presented in Fig. 7. Nepheline syenite $\left(\mathrm{La} / \mathrm{Sm}_{\mathrm{N}}=0.6-13.9\right.$; average $6.1 ; n=32$; subscript $\mathrm{N}$ denotes chondrite-normalized) and nephelinite $\left(\mathrm{La} / \mathrm{Sm}_{\mathrm{N}}=2.5-10.6\right.$; average $6.6 ; n=7$ ) show similar REE patterns indicating high LREE/ HREE fractionation (Fig. 7a and c). Syenites $\left(\mathrm{La} / \mathrm{Sm}_{\mathrm{N}}=0.3-27.8\right.$; average $5.7 ; n=113$ ) display wide variability in REE abundances, and show a range of REE patterns with a distinct negative Eu anomaly in few samples (Fig. 7b). The REE patterns of high silica rock (La/ $\mathrm{Sm}_{\mathrm{N}}=2.3-9$; average $\left.6.3 ; n=11\right)$ as well as the mafic rock $\left(\mathrm{La} / \mathrm{Sm}_{\mathrm{N}}\right.$ $=0.9-8.6$; average $2.6 ; n=46$ ) exhibit both negative and positive Eu anomalies, indicating the role of plagioclase fractionation or presence of plagioclase in the source (Fig. 7d and e). Mafic rocks mostly show flat REE patterns $\left(\mathrm{La} / \mathrm{Sm}_{\mathrm{N}}=2.6\right.$; Fig. 7e) with few showing slightly steeper patterns (with LREE enrichment) as observed in the nephelinite. Compared with the REE patterns of Proterozoic alkaline rocks, Proterozoic carbonatite shows much steeper patterns (Fig. 7f, $n=122)$, and high degree of LREE/HREE fractionation $\left(\mathrm{La} / \mathrm{Sm}_{\mathrm{N}}=\right.$ $0.8-23.5$; average $4.9 ; n=98)$. These are characterized with an average $(\mathrm{La} / \mathrm{Lu})_{\mathrm{N}}$ ratio of $139(n=93)$, indicating derivation from low degree partial melting. The $(\mathrm{La} / \mathrm{Lu})_{\mathrm{N}}$ ratio in nepheline syenite $(38 ; n=32)$, nephelinite $(31 ; n=7)$, syenite $(34 ; n=111)$, high silica rock $(22 ; n$ $=11)$, and mafic rock $(19 ; n=45)$ indicate comparatively higher degree of melting than the carbonatite. Note that the South Indian carbonatites (Sevattur, Samalpatti, Pakkanadu, Hogenakal, and Jokipatti complexes; $n=96)$ show a wide range of REE abundances compared to the Newania carbonatite $(n=21)$ and Purulia carbonatite $(n=5)$ (Fig. 7f).

\section{Radiogenic $\mathrm{Sr}-\mathrm{Nd}-\mathrm{Pb}$ isotope compositions}

The variability in the ${ }^{87} \mathrm{Sr} /{ }^{86} \mathrm{Sr}_{\mathrm{i}}$ and $\varepsilon_{\mathrm{Nd}(\mathrm{i})}$ isotopic compositions (i stands for initial isotopic ratios) of Proterozoic ARCs are presented in Fig. 8, which also shows the average compositions of various mantle sources such as the depleted MORB mantle (DMM), HIMU (high $\mu$, $\mu={ }^{238} \mathrm{U} / 204 \mathrm{~Pb}$ ), EMI (enriched mantle I), and EMII (enriched mantle II) (Zindler and Hart, 1986). The average composition of possible assimilants that can contaminate the mantle-derived primary magma, such as the basement granite (Upadhyay et al., 2006a), fenitized country rock (Upadhyay et al., 2006b), regional granite (Ackerman et al., 2017), upper continental crust (UCC; Millot et al., 2004), and lower continental crust (LCC; Rudnick and Goldstein, 1990) are also plotted in Fig. 8a. Two main clusters are observed for the alkaline rocks in the ${ }^{87} \mathrm{Sr} /{ }^{86} \mathrm{Sr}_{\mathrm{i}}$ and $\varepsilon_{\mathrm{Nd}(\mathrm{i})}$ space. The first cluster dominantly contains samples of nepheline syenite and nephelinite that lie close to the bulk silicate earth (BSE), and also display slight enrichment (low $\mathrm{Sm} / \mathrm{Nd}$ ) as indicated by the negative $\varepsilon_{\mathrm{Nd}(\mathrm{i})}$ values of -4.6. The second cluster mostly comprises the syenite samples having high ${ }^{87} \mathrm{Sr} /$ ${ }^{86} \mathrm{Sr}_{\mathrm{i}}(0.7025-0.7059$, excluding three higher values going up to 0.7734 given by Vijaya Kumar et al., 2007) and low $\varepsilon_{\mathrm{Nd}(\mathrm{i})}(-1.3$ to -14.1 ; mostly around -10), indicating a distinctly enriched source or possible contamination of primary magma with crustal basement rocks (Fig. 8a). Some of the mafic and all high silica rocks show large isotopic variability indicating significant contamination of the parental magmas. Most of the syenites plot close to the basement granite, indicating possible crustal assimilation of parental syenitic magma. The Sr-Nd isotopic variability in the nepheline syenite and nephelinite can be explained by mixing of HIMU and EMI-derived melts that were later contaminated by basement granite or regional granitic end-members.

Only few ${ }^{87} \mathrm{Sr} /{ }^{86} \mathrm{Sr}_{\mathrm{i}}$ and $\varepsilon_{\mathrm{Nd}(\mathrm{i})}$ isotope compositions of Proterozoic carbonatite of India have been reported in the literature (Natarajan et al., 1994; Kumar et al., 1998; Schleicher et al., 1998; Veena et al., 1998; Miyazaki et al., 2000; Srivastava et al., 2005; Srivastava and Sinha, 2007; Ackerman et al., 2017). The initial ${ }^{87} \mathrm{Sr}^{86} \mathrm{Sr}_{\mathrm{i}}$ and $\varepsilon_{\mathrm{Nd}(\mathrm{i})}$ isotope compositions of carbonatite were calculated using their 

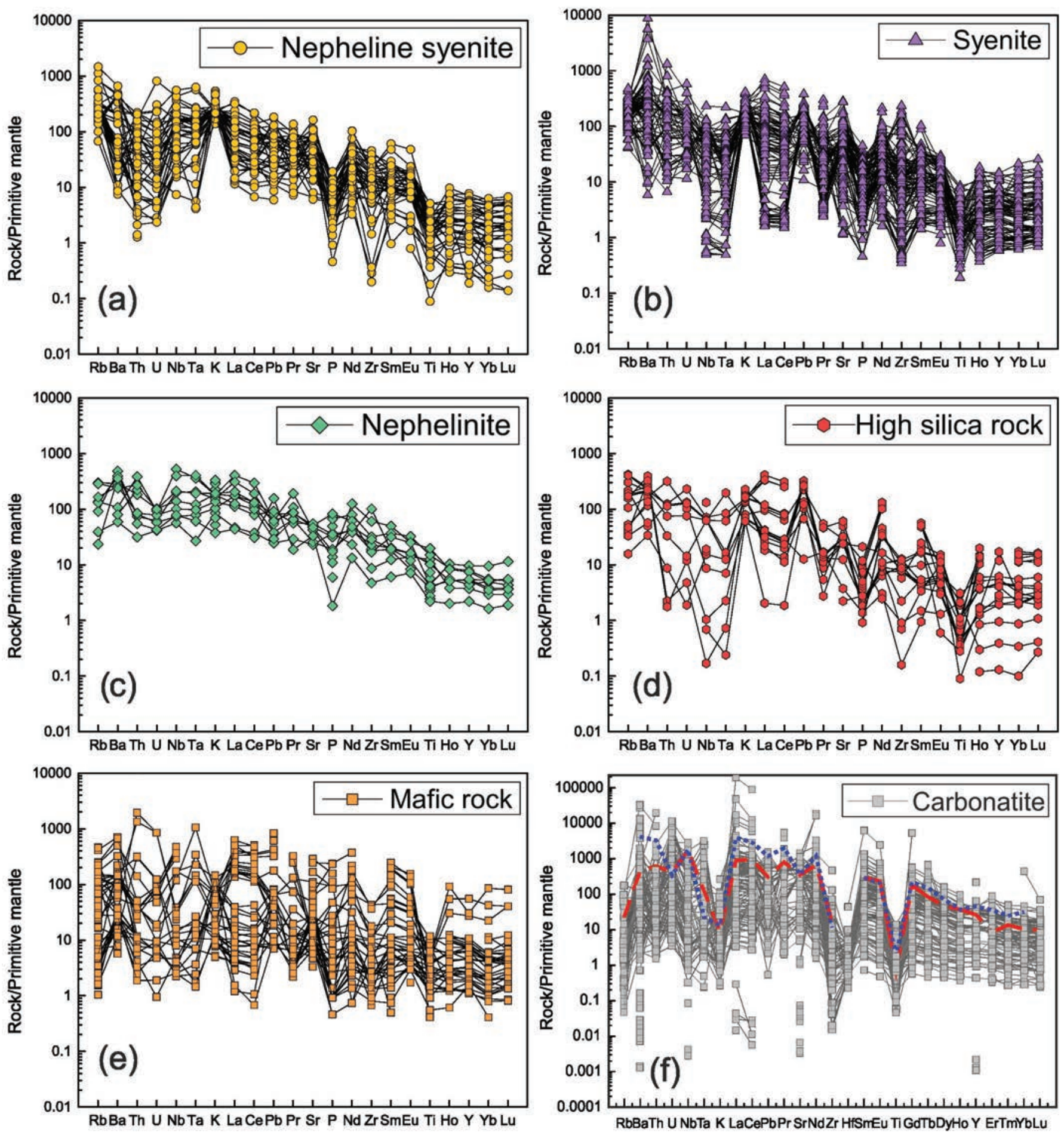

Figure 6. Primitive mantle (Sun and McDonough, 1989) normalized trace elements compositions of (a) nepheline syenite ( $n=45)$, (b) syenite $(n=146),(c)$ nephelinite $(n=9),(d)$ high silica rocks such as alkali feldspar granite, alkali granite, granodiorite, and melatonalite $(n=19)$, (e) mafic rock $(n=62)$, and $(f)$ carbonatite $(n=166)$ of Indian Proterozoic alkaline complexes; the global average compositions of calciocarbonatite (dashed red line) and ferrocarbonatite (dotted purple line) are adopted from Woolley and Kempe (1989).

corresponding emplacement ages and the reported present-day parent/ daughter ratios. The Sevattur, Samalpatti, Jokipatti, and Pakkanadu carbonatite complexes of Tamil Nadu exhibit a wider variation in $\varepsilon_{\mathrm{Nd}(i)}(-4.3$ to -10.3$)$ for a restricted range of ${ }^{87} \mathrm{Sr} /{ }^{86} \mathrm{Sr}_{\mathrm{i}}$ ratios $(0.7045-$ 0.7054 ) and mostly plot near the EMI component. The Samalpatti carbonatite has the highest ${ }^{87} \mathrm{Sr} /{ }^{86} \mathrm{Sr}_{\mathrm{i}}$ and lowest $\varepsilon_{\mathrm{Nd}(\mathrm{i})}$, whereas the Hogenakal carbonatite has the lowest ${ }^{87} \mathrm{Sr} /{ }^{86} \mathrm{Sr}_{\mathrm{i}}$ and the highest $\varepsilon_{\mathrm{Nd}(\mathrm{i})}$
(Fig. 8b). Note that the Newania and Hogenakal carbonatite plot in the depleted quadrant and show similar $\varepsilon_{\mathrm{Nd}(\mathrm{i})}$ (and to an extent similar ${ }^{87} \mathrm{Sr} /{ }^{86} \mathrm{Sr}_{\mathrm{i}}$ ) values as those of nepheline syenite and nephelinite (Fig. 8a). Interestingly, the ${ }^{87} \mathrm{Sr} /{ }^{86} \mathrm{Sr}_{\mathrm{i}}$ and $\varepsilon_{\mathrm{Nd}(\mathrm{i})}$ values of Tamil $\mathrm{Nadu}$ carbonatite overlap with those of syenite (see Fig. 8a). The $\mathrm{Sr}-\mathrm{Nd}$ isotopic compositions of Indian Proterozoic carbonatite $\left({ }^{87} \mathrm{Sr} /{ }^{86} \mathrm{Sr}_{\mathrm{i}}\right.$ : $0.7050-0.7054 ; \varepsilon_{\mathrm{Nd}(\mathrm{i})}:-4.3$ to -10.3 , excluding Newania and 

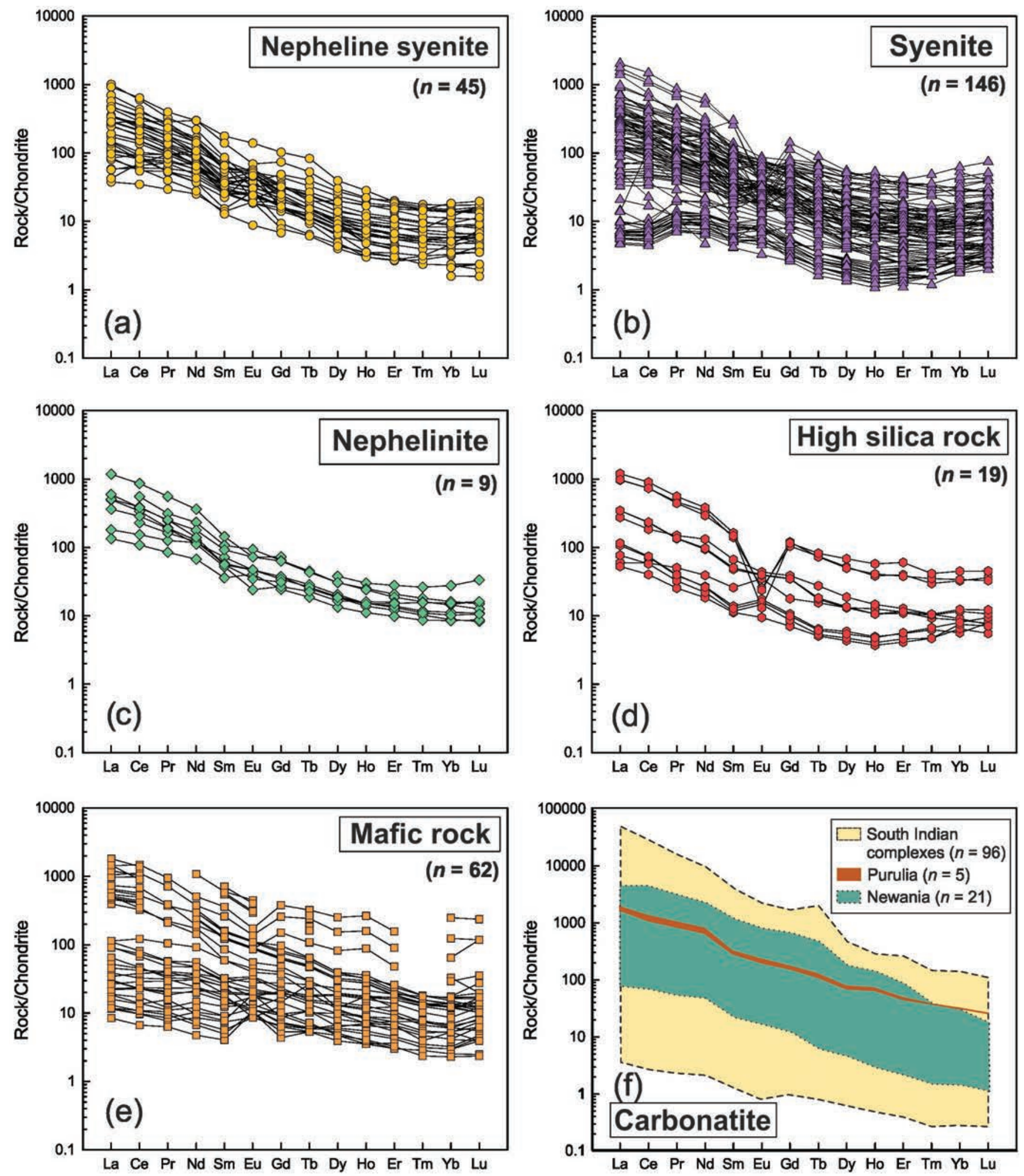

Figure 7. (a-e) Chondrite (Sun and McDonough, 1989) normalized REE patterns of Proterozoic alkaline and associated mafic and high silica rocks. $(f)$ Chondrite normalized REE patterns of Indian Proterozoic carbonatite complexes. The field for South Indian carbonatite complexes includes Sevattur, Samalpatti, Pakkanadu, Hogenakal, Jokipatti and Kambamettu carbonatite complexes of Tamil Nadu.

Hogenakal) are also significantly distinct than that of the Indian Phanerozoic carbonatite such as the Barmer, Amba Dongar, and Sung Valley carbonatite complexes $\left({ }^{87} \mathrm{Sr} /{ }^{86} \mathrm{Sr}_{\mathrm{i}}: 0.7042-0.7076 ; \varepsilon_{\mathrm{Nd}(\mathrm{i})}:+3.1\right.$ to -4.9 ; Chandra et al., 2019).
Considerable variability in the $\mathrm{Pb}$ isotopic composition of alkaline rocks is observed: ${ }^{206} \mathrm{~Pb} / 204 \mathrm{~Pb}$ varies from 15.8 to $20.1,{ }^{207} \mathrm{~Pb} /{ }^{204} \mathrm{~Pb}$ from 15.2 to 15.7 , and ${ }^{208} \mathrm{~Pb} /{ }^{204} \mathrm{~Pb}$ from 35.8 to 45.4 . In the ${ }^{206} \mathrm{~Pb} /$ ${ }^{204} \mathrm{~Pb}$ vs. ${ }^{207} \mathrm{~Pb} / 204 \mathrm{~Pb}$ (Fig. 9a) and ${ }^{208} \mathrm{~Pb} / 204 \mathrm{~Pb}$ (Fig. 9b) space, a linear 

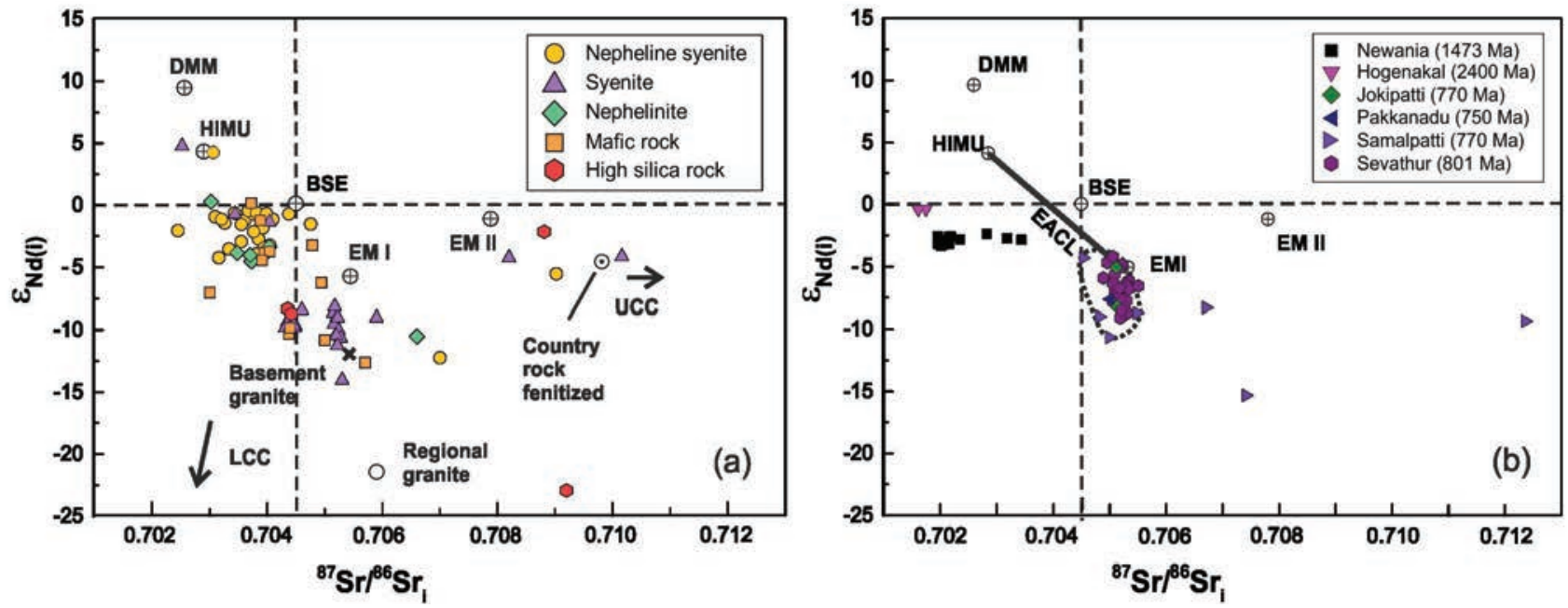

Figure 8. (a) The ${ }^{87} \mathrm{Sr}^{86} \mathrm{Sr}_{i}$ versus $\varepsilon_{\mathrm{Nd}(i)}$ isotopic compositions of Proterozoic alkaline (nepheline syenite, $n=30 ;$ syenite, $n=28 ;$ nephelinite, $n=6)$, associated mafic $(n=13)$, and high silica rock $(n=4)$; subscript $i$ represents initial isotope ratios calculated after correcting for radiogenic growth, considering the age of complexes. Only those data are considered for which both the isotope ratios were measured on the same sample. See Section 4.2.3 for details on various mantle and crustal source compositions. (b) $\mathrm{The}^{87} \mathrm{Sr}^{86}{ }^{86}{ }_{i}$ versus $\varepsilon_{N d(i)}$ in Indian Proterozoic carbonatite complexes $(n=59)$. The East African carbonatite line $(E A C L)$ line represents a reference line for younger East African carbonatites, which are thought to have originated by the mixing between HIMU and EMI end-members (Bell and Tilton, 2002).
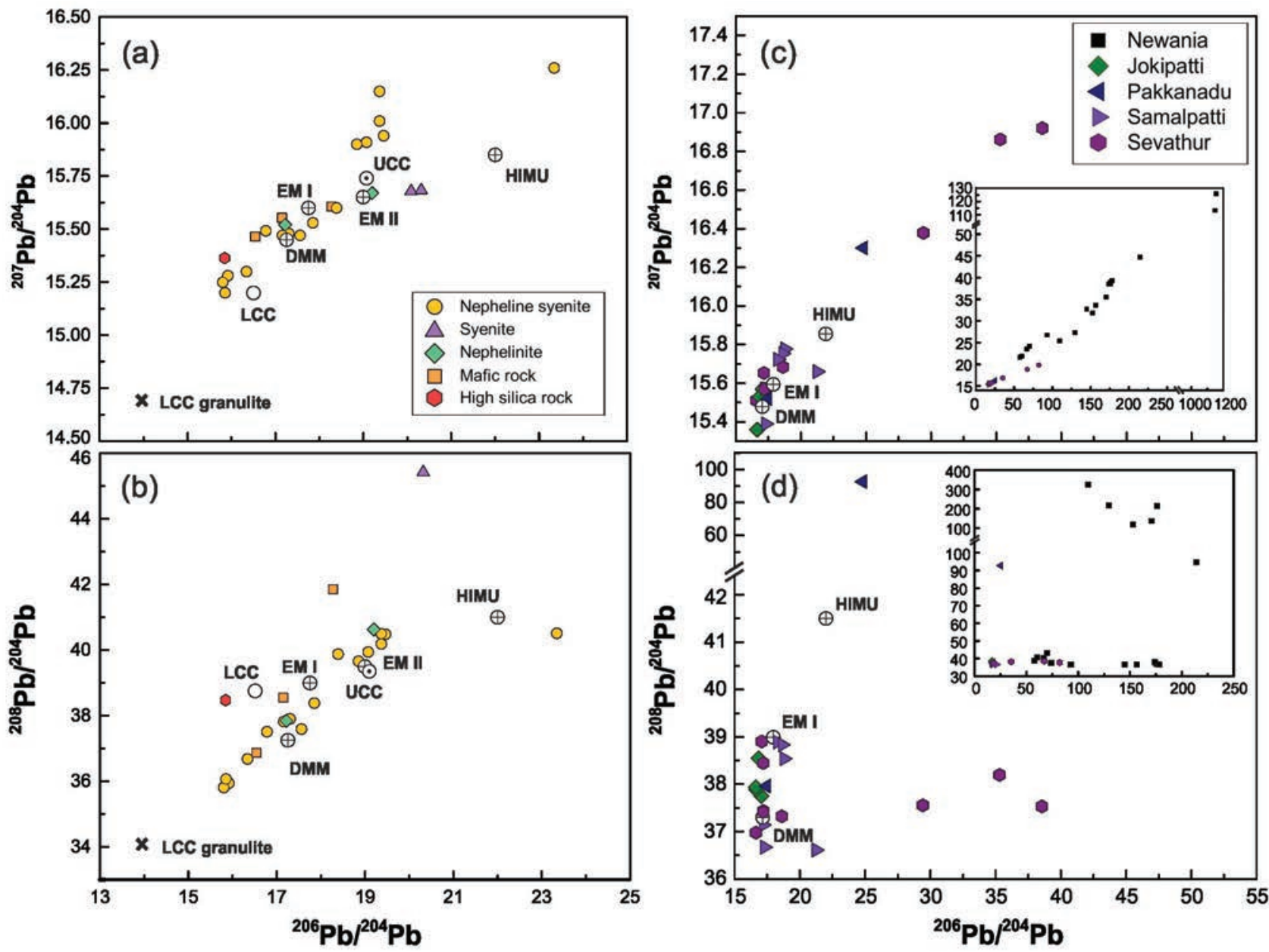

Figure 9. The Pb isotope ratios of ( $(\mathrm{a}$ and $b)$ Proterozoic alkaline (nepheline syenite, $n=16$; syenite, $\boldsymbol{n}=2$; nephelinite, $\boldsymbol{n}=2$ ) and associated mafic $(n=4)$ and high silica rock $(n=1)$ from India; and $(c$ and $d)$ for Proterozoic carbonatites $(n=31$ excluding Newania) from India. Inset shows composition of Newania carbonatites $(n=15)$ that contain unusually high Pb isotope ratios. LCC granulite is from Dickin (1981). Data source for mantle end-members, UCC and LCC are same as in Fig. 8. 


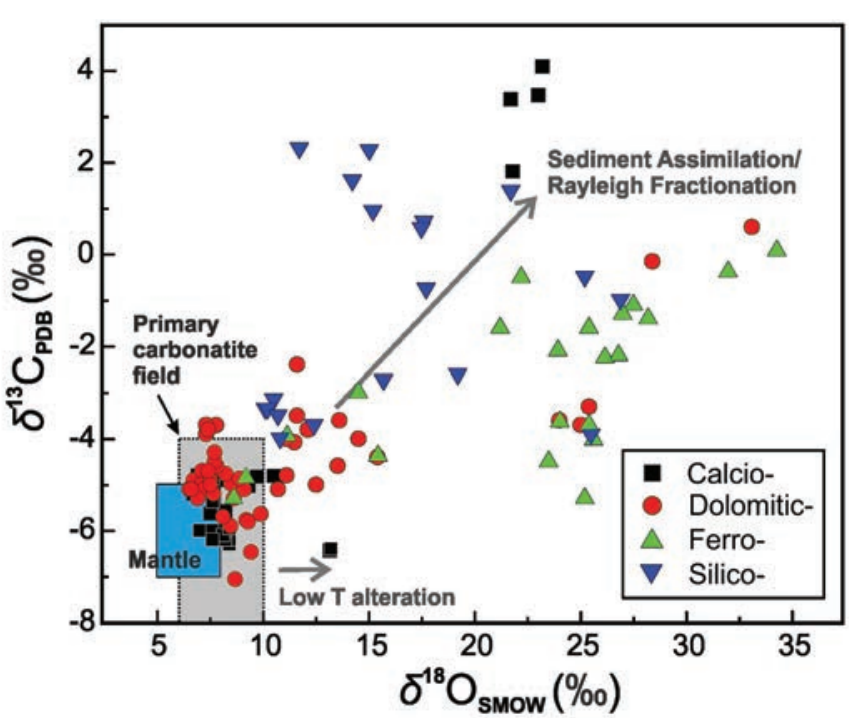

Figure 10. $\delta^{18} \mathrm{O}$ versus $\delta^{13} \mathrm{C}$ compositions $(n=117)$ of Proterozoic carbonatites of India. Blue box represents isotopic composition of mantle (Deines, 1989). Grey box with dotted boundary represents compositional field for mantle-derived primary carbonatites given by Taylor et al. (1967). Processes responsible for change in the isotopic composition of primary carbonatites are indicated by solid arrows (see Deines, 1989). Data are shown for calciocarbonatite $(n=34)$, dolomitic carbonatite $(n=50)$, ferrocarbonatite $(n=15)$, and silicocarbonatite $(n=18)$.

correlation is observed for the alkaline rocks. $\mathrm{Pb}$ isotopic composition of alkaline rocks overlap with that of the associated mafic rock. $\mathrm{Pb}$ isotopic variability in the Indian Proterozoic carbonatite is shown in Fig. 9c and 9d. Note the unusually large variation in the Newania carbonatite $\left({ }^{206} \mathrm{~Pb} /{ }^{204} \mathrm{~Pb}: 60-1157 ;{ }^{207} \mathrm{~Pb} / 204 \mathrm{~Pb}: 22-126 ;{ }^{208} \mathrm{~Pb} / 204 \mathrm{~Pb}\right.$ : 36-325). All Proterozoic carbonatite complexes show a restricted range of ${ }^{208} \mathrm{~Pb} /{ }^{204} \mathrm{~Pb}$ for a large variation in ${ }^{206} \mathrm{~Pb} /{ }^{204} \mathrm{~Pb}$ (Fig. 9d).

\section{Stable $C$ and $O$ isotope data}

The stable oxygen $\left(\delta^{18} \mathrm{O}_{\mathrm{PDB}}\right)$ and carbon $\left(\delta^{13} \mathrm{C}_{\mathrm{SMOW}}\right)$ isotope compositions of Proterozoic carbonatites of India (Sarkar and

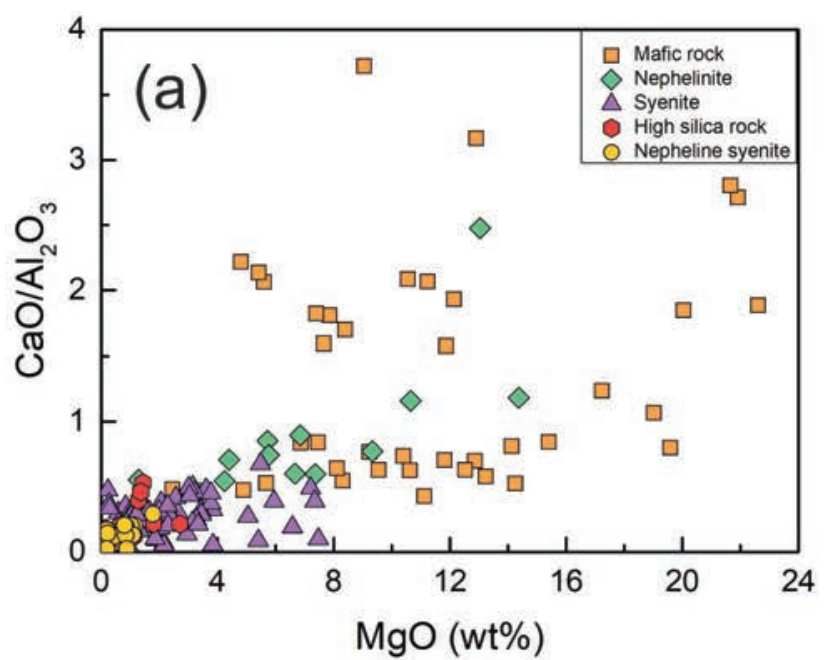

Bhattacharya, 1992; Natarajan et al., 1994; Kumar et al., 1998; Schleicher et al., 1998; Viladkar, 1998; Pandit et al., 1998 and 2002; Miyazaki et al., 2000; Pandit and Golani, 2001; Ray et al., 2013), are represented in Fig. 10. Majority of the dolomitic carbonatite from Newania and calciocarbonatite from Hogenakal and Sevattur plot within the compositional field of the mantle-derived primary carbonatite (Taylor et al., 1967), out of which few lie within the compositional field of mantle (Deines, 1989). Although, two ferrocarbonatite from Sevattur (Schleicher et al., 1998) and Pakkanadu (Pandit et al., 1998) also plot within the primary carbonatite field, the rest have higher $\delta^{18} \mathrm{O}(+8.6$ to $+34.3 \%$ ) and $\delta^{13} \mathrm{C}(-4.85$ to $+0.08 \%$ ) values than the primary carbonatite. Few dolomitic carbonatite shows very high $\delta^{18} \mathrm{O}(+24$ to $+33.1 \%$ ) and $\delta^{13} \mathrm{C}(-3.6$ to $+0.6 \%)$. Silicocarbonatites $\left(\delta^{18} \mathrm{O}:+10.1\right.$ to $+26.9 \%$; $\delta^{13} \mathrm{C}:-4$ to $+2.3 \%$ o) are compositionally distinct than the other carbonatites.

\section{Discussion}

\section{Parental magmas of Proterozoic ARCs and their source(s)}

Based on the available information on geochemical data, i.e., major oxides, trace elements, and radiogenic $\mathrm{Sr}-\mathrm{Nd}-\mathrm{Pb}$ and stable $\mathrm{C}$ and $\mathrm{O}$ isotope compositions of Proterozoic ARCs, we attempt to characterize the source(s) of different Proterozoic ARCs in India. In the $\mathrm{MgO}$ vs. $\mathrm{CaO} / \mathrm{Al}_{2} \mathrm{O}_{3}$ plot (Fig. 11a), a large scatter is observed, albeit a weak positive correlation, which indicates the role of fractional crystallization in the compositional evolution of Proterozoic alkaline and associated rocks. The La vs. La/Sm plot (Fig. 11b) shows weak positive correlations for most of the rock types, except for the mafic rock, indicating a role of partial melting in the compositional evolution of magma. The effect of fractional crystallization (e.g., spinel, plagioclase, clinopyroxene and amphibole) is more prominent in mafic rock as well as in nephelinite and syenite that display a constant $\mathrm{La} /$ $\mathrm{Sm}$ ratio with increasing La content. Despite large variability, somewhat comparable primitive-mantle normalized trace element patterns (Fig. 6) of alkaline rocks suggest its origin by similar petrogenetic processes.

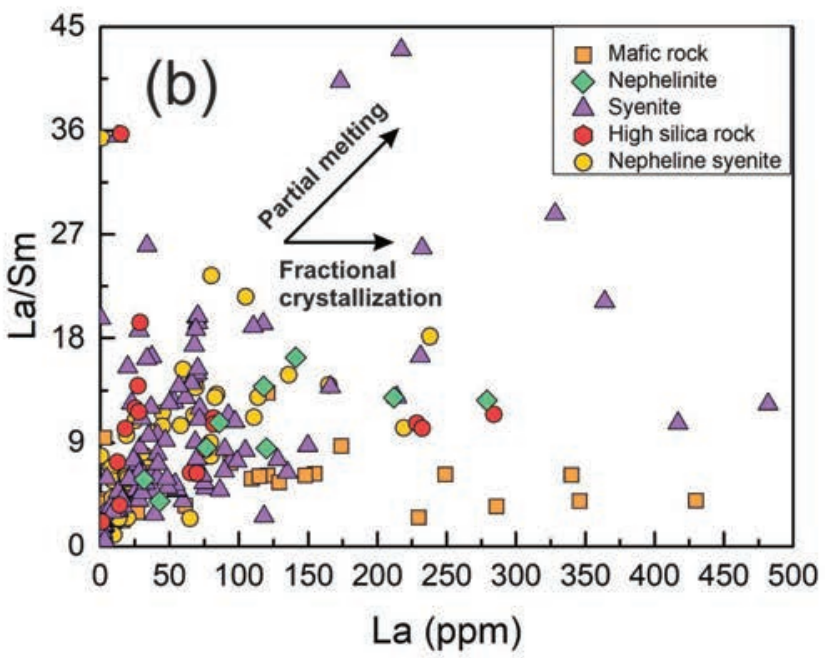

Figure 11. Geochemical relation of Proterozoic alkaline rocks, mafic and high silica rocks in bivariate plots of (a) $\mathrm{MgO}_{\mathrm{Os}} \mathrm{CaO} / \mathrm{Al}_{2} \mathrm{O}_{3}$, and (b) La vs. La/Sm. 
However, stable $\mathrm{C}$ and $\mathrm{O}$ isotope compositions are sensitive to alteration and therefore can be used to understand mantle-lithosphere interaction, effect of secondary processes, low temperature alteration, and crustal assimilation. Most of the Newania and Hogenakal carbonatite complexes of Paleoproterozoic age retain the primary $\delta^{18} \mathrm{O}$ and $\delta^{13} \mathrm{C}$ compositions, but Neoproterozoic carbonatite complexes show higher $\delta^{18} \mathrm{O}$ and $\delta^{13} \mathrm{C}$ values (Fig. 10). Similar variation is observed for the Phanerozoic carbonatite complexes of India such as Amba Dongar, Barmer, and Sung Valley. In general, Phanerozoic carbonatite complexes have higher $\delta^{18} \mathrm{O}$ and $\delta^{13} \mathrm{C}$ compared to the Proterozoic carbonatite (Ray and Ramesh, 2006). Rayleigh fractionation which is considered as the major fractionating process may not produce $\delta^{18} \mathrm{O}$ values much greater than $+17 \%$ (Deines, 1989). Sedimentary components can produce higher $\delta^{18} \mathrm{O}$ values from $+20 \%$ o to more than $+30 \%$ o. It is not clear at this stage if the younger carbonatite is more susceptible to crustal assimilation and/or low temperature alteration.

To explain the origin of alkaline rocks from various Proterozoic ARCs, earlier workers have invoked different parent magmas that were subsequently modified by crystal fractionation and crustal contamination. Based on enriched LILE, HFSE, and the LREE concentrations as well as $\mathrm{Sr}-\mathrm{Nd}-\mathrm{Pb}$ compositions, Upadhyay et al. (2006a, b) and Upadhyay and Raith (2006a, b) concluded that the sources of parental magmas of the alkaline rocks of Khariar, Elchuru, Jojuru, and the Kunavaram complexes must be enriched and located in the subcontinental lithospheric mantle (SCLM). According to these authors, partial melting of a metasomatized spinel lherzolite mantle generated a basanitic primary magma, which experienced fractionation of clinopyroxene and Ti-rich amphibole and formed the parental alkaline magma that intruded these complexes. Previous geochemical studies, using $\mathrm{Sr}-\mathrm{Nd}-\mathrm{Pb}$ isotopic composition and $\mathrm{U}-\mathrm{Pb}$ and $\mathrm{Lu}-\mathrm{Hf}$ in zircons retrieved from ARCs from SGT, have argued for an enriched SCLM source for the generation of these alkaline magmas (Kumar et al., 1998; Schleicher et al., 1998, Miyazaki et al., 2003; Vijaya Kumar et al., 2007; Santosh et al., 2014; Renjith et al., 2016b; Sridhar et al., 2018).

Petrographic as well as geochemical (including isotopic composition) signatures in Proterozoic carbonatite have been used to argue for sources located both in the SCLM and in the deep mantle. For example, Natarajan et al. (1994) suggested the generation of Hogenakal carbonatite and pyroxenite from a SCLM source depleted in incompatible elements prior to 2400Ma. But, Kumar et al. (1998) suggested derivation of Hogenakal and Sevattur carbonatite from an enriched source within the SCLM. Later, Pandit et al. (2002) argued for a depleted mantle source for Hogenakal and an EMI source for other carbonatite complexes (younger than $770 \mathrm{Ma}$ ) from Tamil Nadu. Based on stable $\delta^{13} \mathrm{C}$ and $\delta^{18} \mathrm{O}$ isotope composition of carbonatite that fall within the compositional field of primary mantle (Fig. 10), Schleicher et al. (1998) suggested a primary mantle origin for the Tamil Nadu carbonatite, and argued that $\mathrm{Pb}$ isotope compositions require mixing of depleted mantle and enriched mantle end-member sources. Based on $\mathrm{Sr}-\mathrm{Nd}$ isotopic data, trace element modelling, high $\mathrm{Mg}^{2+} /\left(\mathrm{Mg}^{2+}+\mathrm{Fe}^{2+}\right)$, low REE (and high $\mathrm{Sr}$ concentration), and mantle like $\mathrm{Nb} / \mathrm{Ta}$ ratios in Newania carbonatite, Ray et al. (2013) proposed the existence of a primary magnesiocarbonatite melt derived from a metasomatized lithospheric mantle, i.e., low-degree partial melting $(\sim 0.1 \%)$ of a magnesite and phlogopite-garnet bearing peridotite source. It can be concluded that the alkaline as well as the carbonatite from Proterozoic alkaline complexes are likely to have originated from a metasomatized SCLM source, which is generally incompatible elements enriched.

\section{Temporal evolution of the source of ARCs}

As mentioned earlier, the ${ }^{87} \mathrm{Sr} /{ }^{86} \mathrm{Sr}_{\mathrm{i}}, \varepsilon_{\mathrm{Nd}(\mathrm{i})}$ and $\mathrm{Pb}$ isotopic compositions of most of alkaline rocks and carbonatites are similar to each other (Figs. 8 and 9). For example, the ${ }^{87} \mathrm{Sr}^{86} \mathrm{Sr}_{\mathrm{i}}$ and $\varepsilon_{\mathrm{Nd}(\mathrm{i})}$ isotopic composition of syenite and carbonatite overlap with each other (Fig. 8). Nepheline syenite also shows similar ${ }^{87} \mathrm{Sr} /{ }^{86} \mathrm{Sr}_{\mathrm{i}}$ and $\varepsilon_{\mathrm{Nd}(\mathrm{i})}$ as Newania carbonatite. Same observations can be seen in the $\mathrm{Pb}-\mathrm{Pb}$ array (Fig. 9). Variability in $\mathrm{Sr}, \mathrm{Nd}$, and $\mathrm{Pb}$ isotope ratios of these ARCs can arise due to variable amount of crustal assimilation with the parental magma. Interestingly, Figure 12 reveals temporal variations of ${ }^{87} \mathrm{Sr} /{ }^{86} \mathrm{Sr}_{\mathrm{i}}$ and $\varepsilon_{\mathrm{Nd}(\mathrm{i})}$ in the Proterozoic ARCs. The gradual enrichment in ${ }^{87} \mathrm{Sr} /{ }^{86} \mathrm{Sr}_{\mathrm{i}}$ and depletion in $\varepsilon_{\mathrm{Nd}(\mathrm{i})}$ isotope ratios with time is clearly observed in Indian Proterozoic alkaline and carbonatite complexes (Fig. 12). In general, the isotopic composition of source of ARCs, even assuming some crustal contamination of parental magma, has changed with time during the Proterozoic, shifting systematically towards more enriched signatures, i.e., an increase in ${ }^{87} \mathrm{Sr}^{86} \mathrm{Sr}_{\mathrm{i}}(0.702$ to 0.708$)$ and decrease in $\varepsilon_{\mathrm{Nd}(\mathrm{i})}(-1.3$ to -14.1$)$ over a 2 Gyr duration. Such a general progression can be observed even for individual rock types, for example note the progressive change in the isotopic composition of syenite of different ages. Same can also be observed as one progresses from Hogenakal (higher $\varepsilon_{\mathrm{Nd}(\mathrm{i})}$ ) to Newania (intermediate $\varepsilon_{\mathrm{Nd}(\mathrm{i})}$ ) to other Tamil Nadu carbonatite having the lowest $\varepsilon_{\mathrm{Nd}(\mathrm{i})}$ (Fig. 12c and d). These lines of evidence strongly suggest that the source of these ARCs, presumably the Indian SCLM, has become more enriched with younger age. The exact mechanism for such an enrichment cannot be ascertained at this point, but we believe that metasomatism by mantle-derived fluids likely have caused source enrichment.

\section{Carbonatite and their link to Large Igneous Provinces (LIPs)}

Carbonatite of Proterozoic to Recent age are mostly located in stable intraplate settings near rift or shear zones. Irrespective of emplacement ages of Indian carbonatite complexes that vary from Proterozoic to Cretaceous, carbonatites are spatially and temporally associated with a wide variety of alkaline, mafic, and ultramafic silicate rocks, as observed elsewhere (see Table 1; Woolley and Kjarsgaard, 2008). To explain the association of carbonatite and alkaline rocks, three major hypotheses on the generation of carbonatite have been proposed: (1) Fractional crystallization (Lee and Wyllie, 1994), (2) liquid immiscibility of carbonated alkaline silicate magmas (Brooker and Kjarsgaard, 2011), and (3) partial melting of carbonated mantle peridotite (Wallace and Green, 1988) or carbonated eclogite (Nelson et al., 1988). Although, several studies argue for a mantle origin of the carbonatite, the exact nature and composition of the mantle source are still debated (Ernst and Buchan, 2004; Bell and Simonetti, 2010; Ernst and Bell, 2010). In addition, the existence and nature of primitive/parental carbonatite melt within the mantle is still debated (Bell and Simonetti, 2010, Chandra et al., 2018), as well as the composition of such melt which can be dolomitic carbonatite, calcite carbonatite, calcite-dolomite, or magnesite carbonatite in nature (Isshiki et al., 2004).

Occurrence of several carbonatite complexes and associated 

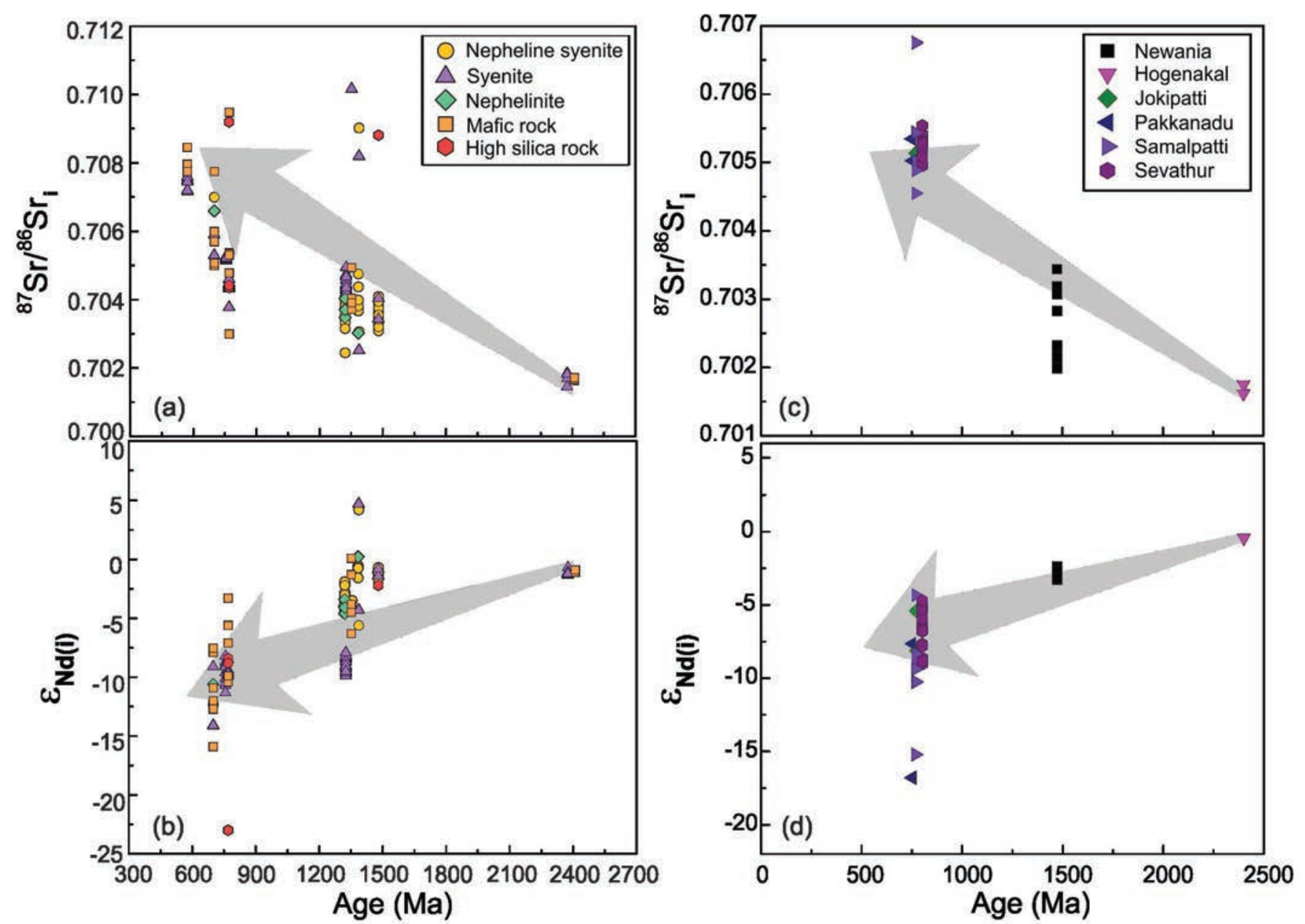

Figure 12. Temporal variations in ${ }^{87} \mathrm{Sr}^{86} \mathrm{Sr}_{i}$ and $\varepsilon_{\mathrm{Nd}(\mathrm{i})}$ of Indian Proterozoic (a and b) alkaline and associated mafic and high silica rocks, and $(c$ and $d)$ carbonatites. Arrow indicates a general trend toward more enriched signatures with younger age.

silicate rocks globally within LIPs, has encouraged others to propose a genetic linkage between these rocks and mantle-plume originated LIPs (Ernst and Buchan, 2004; Ernst and Bell, 2010; Wu et al., 2011; Ciborowski et al., 2017). Ernst and Bell (2010) have documented Proterozoic and Phanerozoic carbonatite occurrences worldwide, which are located within $1000 \mathrm{~km}$ radius of nearby LIPs. A few Proterozoic carbonatite complexes have been associated with the mantle-plume generated LIPs; emplacement age of carbonatite is similar to the age of the LIP. These include Phalaborwa and Shield carbonatite complexes of the 2055 Ma old Bushveld LIP in South Africa (Wu et al., 2011); several carbonatite bodies associated with the Central Iapetus Magmatic Province in St-Honore of eastern Laurentia (642 Ma); Alnö (Sweden, $589 \mathrm{Ma}$ ) and Fen (Norway, 583 Ma) carbonatite (Ernst and Buchan, 2004); and carbonatite of CircumSuperior LIP ( 1880 Ma; Ciborowski et al., 2017). Furthermore, studies have proposed that some Proterozoic carbonatite complexes originated from mantle plumes, but no LIP occurs in the area, for example the 730-670 Ma old carbonatite of the Yenisei Ridge, Central Siberia (Vrublevskii et al., 2011).

In the Indian context, no Proterozoic carbonatite complex has been linked to mantle-plume originated LIP, although several studies have established a link between the Phanerozoic Indian carbonatites, such as Amba Dongar, Barmer, Mundwara, Sung Valley, Swangkre, Samchampi, and Jarsa carbonatite complexes, with Deccan-Reunion and Kerguelen mantle plumes (e.g., Basu et al., 1993; Sen et al., 2009; Veena et al., 1998; Ray et al., 2000; Heaman et al., 2002; Srivastava and Sinha, 2007; Chandra et al., 2018, 2019). The origin of Phanerozoic carbonatite and alkaline complexes, particularly Amba Dongar, Barmer, Mundwara, Phenai Mata, and Bhuj that occur along the Narmada-Son lineament has been linked to the mantle plume activity 68-65 Ma ago that formed the Deccan flood basalts (Basu et al., 1993; Sen et al., 2009), strengthening the argument that ARC magmatism is related to mantle plume activity.

\section{Geodynamic setting for the origin of ARCs}

Several petrogenetic and evolutionary models for the generation of Proterozoic ARC complexes have been proposed based on the inferences from field evidences, structural and textural signatures, petrography and mineral chemistry, geochemistry, and geochronology of alkaline rocks (e.g., Aftalion et al., 2000; Burke et al., 2003; Burke and Khan, 2006; Upadhyay et al., 2006a, b; Upadhyay and Raith, 2006a, b; Vijaya Kumar et al., 2007, 2011; Upadhyay, 2008; Dasgupta et al., 2013, 2017). These studies generally agree that deformation of already formed ARCs during continental and arc-continental collisions gave rise to DARCs, and represent two parts of the Wilson cycle signifying opening and closing of an ocean (Burke et al., 2003; Burke and Khan, 2006; Leelanandam et al. 2006; Upadhyay et al., 2006a, 
b; Upadhyay and Raith, 2006a, b; Upadhyay, 2008; Ashwal et al., 2016).

The Wilson cycle begins with the development of rifts in continental extensional regimes and emplacement of parental alkaline magmas. New ocean basins are created with continual extension of rift basins and formation of alkaline bodies. The already formed alkaline complexes are preserved on the drifted continental margins. In the second phase of the Wilson cycle, that is the closing of the ocean, the pre-existing ARCs are deformed and metamorphosed (develop a gneissic fabric) during continent-continent or arc-continent collision and form DARCs. The locus of these well-preserved DARCs marks the suture zone. Some of these DARCs, during subduction, reach a depth of $100 \mathrm{~km}$ and remain preserved within the SCLM, whilst few also remain preserved within the crust (Burke et al., 2003; Burke and Khan, 2006). After hundreds of millions of years of non-magmatic activity, the DARCs preserved in SCLM serve as the source for a new ARC in the area, as plate dynamics renews rifting along the suture zone. This is an extension of the idea proposed by Bailey (1977) to explain repetitive magmatic activities observed in the ARC complexes of the same locality over hundreds of million years.

Later, Burke and Khan (2006) proposed two models for the origin of ARCs: (1) the plume model, and (2) the DARC model. In the plume model, they argued that ARC magmas are sourced from mantle plumes, which they define to be as any source located within the convecting mantle (and hence not a part of SCLM) carrying distinct chemical signatures than the ambient mantle. In the DARC model, new generation of ARCs are formed from partial melting of DARCs that were stored in the lithospheric mantle during a past subduction event; this is similar to that proposed by Burke et al. (2003). However, these models are silent about the exact mechanism (and source) of formation of first-generation ARC that subsequently form DARC. Further, given the similarity in the chemical composition of DARCs and younger ARCs of a region, extensive melting of DARCs that is melting of entire source would be required to generate the new ARCs.

Below, we discuss a petrogenetic model for the origin of Indian Proterozoic ARCs and DARCs, which is mainly based upon earlier ideas proposed for emplacement of ARCs in EGMB and SGT. The model is schematically shown in Fig. 13 and generally agrees with the model of Burke et al. (2003). The proposed model shows three stages of development. In first stage, an intracontinental rift system develops in the southern part of India prior to the collision between Indian and East Antarctic Blocks (Fig. 13a). As a result of rifting and lithosphere thinning, asthenospheric upwelling takes place, which initiates decompressional melting to generate alkaline (nephelinite, phonolite, melilitolite, carbonatite) magmas in the initial phase of intraplate rift setting. We hypothesize that patches of (carbonated) EM-I type material, representing ancient recycled crust, is distributed in the SCLM, imparting an enriched signature to this SCLM source. It is also possible that mantle-derived fluids metasomatizes part of the SCLM, thus imparting distinctly enriched signature. We propose three possibilities for the formation of different rock type of Proterozoic complexes: (A) extremely low-degree partial melts are derived from the upwelling asthenospheric mantle (which may contain EM-I type material) and emplaced directly to the surface along the fault planes of a shear zone, similar to the mantle plume model of Burke and Khan (2006); (B) primary melt derived from SCLM source is differentiated in a crustal magma chamber and form compositionally different ARC magmas, for example, parental melilitite magma can
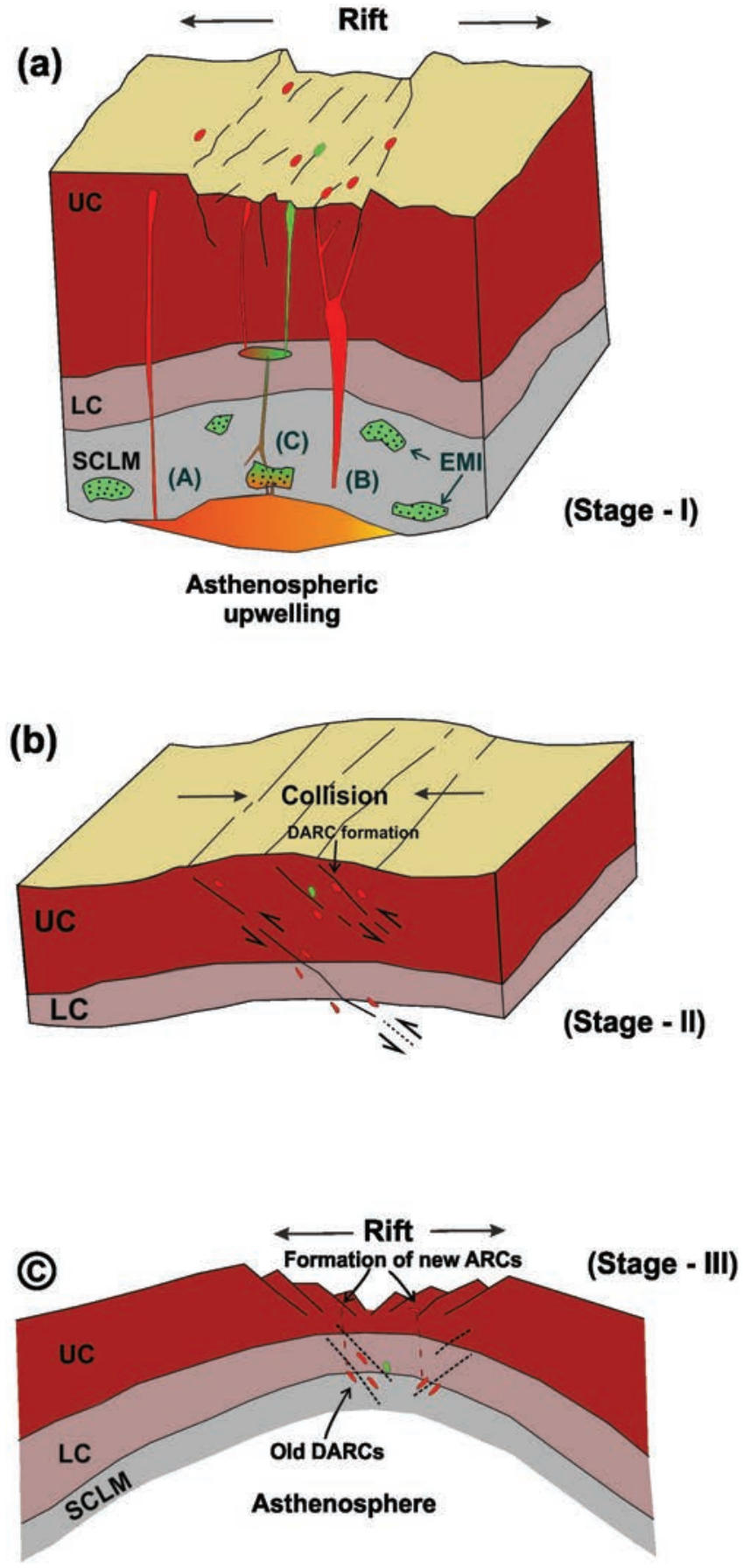

Figure 13. A plausible petrogenetic model proposed for the origin of Proterozoic ARCs shows three major stages for the generation of Proterozoic ARCs. (a) In Stage-I, a rift develops in the Indian block causes asthenospheric upwelling resulting in decompressional melting to generate alkaline magmas in intraplate rift setting. Melts can be generated by melting of asthenospheric material, or EM-I component representing the ancient recycled crust distributed within the SCLM; see Section 5.4 for details. (b) Stage-II, collision between Indian and East Antarctic blocks forms shear zones. In this stage, early formed ARCs get deformed to form DARCs along the shear zone; few of these DARCs reach up to a depth of $\sim 100 \mathrm{~km}$. (c) Stage-III, the area again undergoes renewed intraplate rifting (and crustal thinning) due to asthenosphere upwelling leading to extensive melting of early-formed DARCs that form of a new generation of ARCs. 
generate nephelinite-phonolite-trachyte parental magmas with increasing fractionation; (C) asthenosphere-derived primary melt metasomatizes the EM-I bearing SCLM, and melting of this metasomatized SCLM forms carbonatite and alkaline magmas; these possibilities are shown in Fig. 13a. Furthermore, various possible petrogenetic pathways for the generation of carbonatite magmas are schematically shown in Fig. 14. Despite disagreement on the exact nature of the mantle source, it was commonly argued that Proterozoic ARCs originated from a metasomatized SCLM. Low-degree melting of metasomatized SCLM source can generate carbonated silicate melts, which after liquid immiscibility at crustal depths, form the carbonatite and associated alkaline rocks in a locality (Chandra et al., 2019). Note that similar $\mathrm{Sr}-\mathrm{Nd}-\mathrm{Pb}$ isotopic ratios of carbonatite and associated alkaline rocks from the same complex argue in favour of a common source and that liquid immiscibility does not change the initial isotopic composition. It is unlikely that sources of alkaline and associated carbonatite rocks are different and yet chemically (isotopic composition) similar. In the second stage, shear zones are formed during collision of Indian and East Antarctic blocks (Fig. 13b). The early formed ARCs get deformed to form DARCs along the shear zones. Few of the DARCs can be subducted to about $100 \mathrm{~km}$ depth and become part of the SCLM. In third stage (Fig. 13c), the region again undergoes renewed faulting and rifting (and crustal thinning) due to asthenosphere upwelling under an extensional tectonics regime. This would result in extensive melting of the existing DARCs to

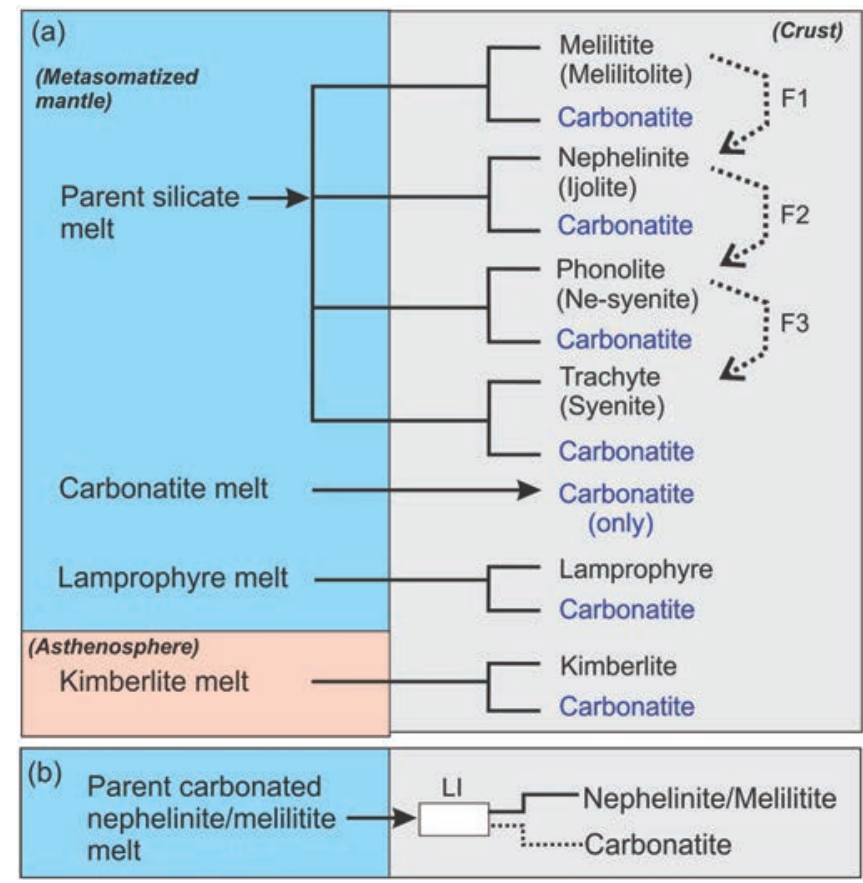

Figure 14. Schematic representation of carbonatite magma generation along with differentiation of silicate rocks as given by Woolley and Kjarsgaard (2008). (a) F1, F2 and F3 denote differentiation of one silicate melt to another silicate melt. Solid line denotes fractional differentiation of silicates as cumulate and emplacement of carbonatite melt in crustal depths. Most of carbonatites are derived from mantle depths except one i.e., kimberlitic melt, which is derived from asthenosphere. (b) Formation of carbonatite and associated silicate rocks via liquid immiscibility (LI) at crustal depth from parental carbonated silicate melt. generate renewed alkaline magmatic activity that formed the Neoproterozoic ARC complexes.

\section{Summary and Concluding remarks}

Alkaline magmatism during the Proterozoic era formed several alkaline rocks (nephelinite, nepheline syenite, syenite) and associated carbonatite complexes, collectively termed as ARCs. These ARCs are mainly concentrated in the Singhbhum Craton, EGMB, Bastar Craton, and SGT along the eastern part of India. Here, we have reviewed the petrology, geochronology, and geochemistry (major oxides, trace elements, and $\mathrm{Sr}-\mathrm{Nd}-\mathrm{Pb}-\mathrm{C}-\mathrm{O}$ isotopic composition) of 38 Proterozoic ARC complexes with an aim to address petrogenesis of these rocks. Geochronological data indicates three prominent phases of alkaline magmatism at 2533-2340 Ma, 1510-1242 Ma, and 833$572 \mathrm{Ma}$ as well as two prominent metamorphic imprints around 950$930 \mathrm{Ma}$ and 570-485 Ma. About $300 \mathrm{Myr}$ long second phase of alkaline magmatism is associated with the Mesoproterozoic rifting (1500-1350 Ma). The first metamorphic event coincides with the Grenvillian Orogeny ( 900-1000 Ma), whereas second events with the Pan-African orogeny ( $\sim 00 \mathrm{Ma})$. Interestingly, two sets of emplacement ages for alkaline rocks for the Koraput ( 860-920 Ma vs. $1387 \pm 34 \mathrm{Ma})$, Rairakhol $(938.8 \pm 3.1 \mathrm{Ma}$ vs. $1372 \pm 5 \mathrm{Ma})$ and Khariar (513 $\pm 18 \mathrm{Ma}$ vs. $1470-1500 \mathrm{Ma})$ suggest recurrence of alkaline magmatism (?), which can be explained by melting of earlyformed ARCs to form the later ARCs.

Nepheline syenite and syenite show distinct depletion of $\mathrm{P}, \mathrm{Zr}$ and $\mathrm{Ti}$, and enrichment of $\mathrm{K}$. Carbonatite shows prominent negative $\mathrm{K}, \mathrm{Zr}$, Hf and Ti anomalies. Chondrite-normalized REE patterns of nepheline syenite, syenite, and nephelinite are similar and show Eu anomaly, indicating the role of plagioclase in the source because plagioclase fractionation has been minor. Carbonatite is enriched in REEs about 10-100 times than the alkaline rocks. Similar Sr-Nd-Pb isotope compositions of alkaline rocks and carbonatite suggest a common mantle source for the generation of these rocks. Temporal variations in the isotopic compositions of ARCs show an enrichment in ${ }^{87} \mathrm{Sr} /{ }^{86} \mathrm{Sr}_{\mathrm{i}}(0.702$ to 0.708$)$ and depletion in $\varepsilon_{\mathrm{Nd}(\mathrm{i})}(-1.3$ to -14.1$)$ over a 2 Gyr duration, which suggest a systematic geochemical evolution of the source of these ARCS, generally becoming more enriched with younger age. We believe that a metasomatized and enriched SCLM source is the most likely source for the generation of these Proterozoic rocks, which imparts a signature dominated by the higher abundance of incompatible elements, e.g., $\mathrm{Ba}, \mathrm{Sr}, \mathrm{Nb}, \mathrm{P}$ and REEs, in both the alkaline rocks and carbonatite. The model proposed by Burke et al. (2003), suggesting the role of Wilson cycle in the origin of ARCs in intracontinental rift settings, seems to be a plausible model. Continental rifting associated with the rise in underlying asthenospheric material (as well as the SCLM) generate alkaline magmas by decompressional melting. These magmas can directly erupt to the surface or undergo differentiation during storage in a crustal magma chamber and subsequently erupt to produce compositionally diverse range of alkaline rocks.

\section{Acknowledgements}

We thank Prof. S. Sensarma and Dr. Fareeduddin for an invitation to submit this work. We are grateful to Aniket Chakrabarty, an anonymous reviewer, and the editor for a detailed review and insightful comments that improved clarity of this work. JC thanks the Director, 
CSIR-NGRI for permission to publish this work (Ref. No. NGRI/ Lib/2019/Pub-87). MH acknowledges CSIR, MHRD, Govt. of India for JRF/SRF fellowship.

\section{References}

Ackerman, L., Magna, T., Rapprich, V., Upadhyay, D., Krátký, O., Èejková, B., Erban, V., Kochergina, Y.V. and Hrstka, T., 2017. Contrasting petrogenesis of spatially related carbonatites from Samalpatti and Sevattur, Tamil Nadu, India. Lithos, 284, pp.257275.

Aftalion, M., Bowes, D.R., Dash, B. and Fallick, A.E., 2000. Late Pan-African thermal history in the Eastern Ghats terrane, India, from $\mathrm{U}-\mathrm{Pb}$ and $\mathrm{K}-\mathrm{Ar}$ isotopic study of the Mid-Proterozoic Khariar alkali syenite, Orissa. Geological Survey of India, (57), pp.26-32.

Ashwal, L.D., Patzelt, M., Schmitz, M.D. and Burke, K., 2016. Isotopic evidence for a lithospheric origin of alkaline rocks and carbonatites: an example from southern Africa. Canadian Journal of Earth Sciences, 53(11), pp.1216-1226.

Bailey, D.K., 1977. Lithosphere control of continental rift magmatism. Journal of the Geological Society, 133(1), pp.103-106.

Basu, S.K. and Bhattacharyya, T., 2014. Petrography and Mineral chemistry of Alkaline-Carbonatite complex in Singhbhum Crustal Province, Purulia Region, Eastern India. Journal of the Geological Society of India, 83(1), pp.54-70.

Basu, A.R., Renne, P.R., Dasgupta, D.K., Teichmann, F. and Poreda, R.J., 1993. Early and late alkali igneous pulses and a high- ${ }^{3} \mathrm{He}$ plume origin for the Deccan flood basalts. Science, 261(5123), pp.902-906.

Bell, K. and Tilton, G.R., 2002. Probing the mantle: the story from carbonatites. Eos, Transactions American Geophysical Union, 83(25), pp.273-277.

Bell, K. and Simonetti, A., 2010. Source of parental melts to carbonatites-critical isotopic constraints. Mineralogy and Petrology, 98(1-4), pp.77-89.

Bhadra, S., Gupta, S., and Banerjee, M., 2004. Structural evolution across the Eastern Ghats Mobile Belt - Bastar craton boundary, India: hot over cold thrusting in an ancient collision zone. Journal of Structural Geology 26(2), pp.233-245.

Bhattacharya, S. and Basei, M., 2010. Contrasting magmatic signatures in the Rairakhol and Koraput alkaline complexes, Eastern Ghats belt, India. Journal of Earth System Science, 119(2), pp.175-181.

Biswal, T.K., De Waele, B. and Ahuja, H., 2007. Timing and dynamics of the juxtaposition of the Eastern Ghats Mobile Belt against the Bhandara Craton, India: A structural and zircon U-Pb SHRIMP study of the fold thrust belt and associated nepheline syenite plutons. Tectonics, 26(4), TC4006.

Brooker, R.A. and Kjarsgaard, B.A., 2011. Silicate-Carbonate Liquid Immiscibility and Phase Relations in the System $\mathrm{SiO}_{2}-\mathrm{Na}_{2} \mathrm{O}-$ $\mathrm{Al}_{2} \mathrm{O}_{3}-\mathrm{CaO}-\mathrm{CO}_{2}$ at $0.1-2.5 \mathrm{GPa}$ with Applications to Carbonatite Genesis. Journal of Petrology, 52, pp.1281-1305.

Burke, K. and Khan, S., 2006. Geoinformatic approach to global nepheline syenite and carbonatite distribution: testing a Wilson cycle model. Geosphere, 2(1), pp.53-60.

Burke, K., Ashwal, L.D. and Webb, S.J., 2003. New way to map old sutures using deformed alkaline rocks and carbonatites. Geology, 31(5), pp.391-394.

Burke, K., Khan, S.D. and Mart, R.W., 2008. Grenville Province and Monteregian carbonatite and nepheline syenite distribution related to rifting, collision, and plume passage. Geology, 36(12), pp.983986.
Catlos, E.J., Dubey, C.S. and Sivasubramanian, P., 2008. Monazite ages from carbonatites and high-grade assemblages along the Kambam fault (southern granulite terrane, South India). American Mineralogist. 93(8-9), pp.1230-1244.

Chakrabarty, A. 2009. Petrogenesis of carbonatite and associated alkaline rocks, Purulia, W.B., India. Ph.D.Thesis, Department of Earth Sciences, Indian Institute of Technology Roorkee

Chakrabarty, A. and Sen, A.K., 2010. Enigmatic association of the carbonatite and alkali-pyroxenite along the Northern Shear Zone, Purulia, West Bengal: A saga of primary magmatic carbonatite. Journal of the Geological Society of India, 76(4), pp.403-413.

Chakrabarty, A., Mitchell, R.H., Ren, M., Saha, P.K., Pal, S., Pruseth, K.L. and Sen, A.K., 2016. Magmatic, hydrothermal and subsolidus evolution of the agpaitic nepheline syenites of the Sushina Hill Complex, India: implications for the metamorphism of peralkaline syenites. Mineralogical Magazine, 80(7), pp.1161-1193.

Chakrabarty, A., Mitchell, R.H., Ren, M., Pal, S., Pal, S. and Sen, A.K., 2018. Nb-Zr-REE re-mobilization and implications for transitional agpaitic rock formation: insights from the Sushina Hill Complex, India. Journal of Petrology, 59(10), pp.1899-1938.

Chalapathi Rao, N.V., Wu, F.Y. and Srinivas, M., 2012. Mesoproterozoic emplacement and enriched mantle derivation of the Racherla alkali syenite, Palaeo-Mesoproterozoic Cuddapah Basin, southern India: insights from in situ $\mathrm{Sr}-\mathrm{Nd}$ isotopic analysis on apatite. Geological Society, London, Special Publications, 365(1), pp.185-195.

Chandra, J., Paul, D., Viladkar, S.G. and Sensarma, S., 2018. Origin of the Amba Dongar carbonatite complex, India and its possible linkage with the Deccan Large Igneous Province. Geological Society, London, Special Publications, 463(1), pp.137-169.

Chandra, J., Paul, D., Stracke, A., Chabaux, F. and Granet, M., 2019. The origin of carbonatites from Amba Dongar within the Deccan Large Igneous Province. Journal of Petrology, 60(6), pp.11191134.

Choudhary, A.K., Gopalan, K. and Sastry, C.A., 1984. Present status of the geochronology of the Precambrian rocks of Rajasthan. Tectonophysics, 105(1-4), pp.131-140.

Ciborowski, T.J.R., Minifie, M.J., Kerr, A.C., Ernst, R.E., Baragar, B. and Millar, I.L., 2017. A mantle plume origin for the Palaeoproterozoic Circum-Superior large Igneous Province. Precambrian Research, 294, pp.189-213.

Clark, G.S. and Subbarao, K.V., 1971. Rb-Sr isotopic age of the Kunavaram Series-a group of alkaline rocks from India. Canadian Journal of Earth Sciences, 8(12), pp.1597-1602.

Collins, A.S., Clark, C., and Plavsa, D., 2014. Peninsula India in Gondwana: the tectonothermal evolution of the southern granulite terrane and its Gondwanan counterparts. Gondwana Research, 25, pp.190-203.

Cox, K.G., Bell, J.D. and Pankhurst, R.J., 1979. The Interpretation of Igneous Rocks. London University, London, $450 \mathrm{p}$.

Crawford, A.R., 1970. The Precambrian geochronology of Rajasthan and Bundelkhand, northern India. Canadian Journal of Earth Sciences, 7(1), pp.91-110.

Das, S., Sanyal, S., Karmakar, S., Sengupta, S. and Sengupta, P., 2018. Do the deformed alkaline rocks always serve as a marker of continental suture zone? A case study from parts of the Chotanagpur Granite Gneissic complex, India. Journal of Geodynamics, 129, pp.59-79.

Dasgupta, S., Bose, S. and Das, K., 2013. Tectonic evolution of the Eastern Ghats belt, India. Precambrian Research, 227, pp.247258.

Dasgupta, S., Bose, S., Bhowmik, S.K. and Sengupta, P., 2017. The Eastern Ghats Belt, India, in the context of supercontinent assembly. Geological Society, London, Special Publications, 
457(1), pp.87-104.

Deans, T. and Powell, J.L., 1968. Trace elements and strontium isotopes in carbonatites, fluorites and limestones from India and Pakistan. Nature, 218(5143), p.750.

Deines, P., 1989. Stable isotope variations in carbonatites. Carbonatites, pp.301-357.

Dickin, A.P., 1981. Isotope geochemistry of Tertiary igneous rocks from the Isle of Skye, NW Scotland. Journal of Petrology, 22(2), pp.155-189.

Ernst, R.E., and Buchan, K.L., 2004. Igneous rock associations in Canada 3. Large Igneous Provinces (LIPs) in Canada and adjacent regions: 3 Ga to present. Geoscience Canada, 31, pp. 103-126.

Ernst, R.E. and Bell, K., 2010. Large igneous provinces (LIPs) and carbonatites. Mineralogy and Petrology, 98(1-4), pp.55-76.

Fermor, S.L.L., 1936. An Attempt at the Correlation of the Ancient Schistose Formations of Peninsular India. Geological survey of India.

Fitton, J.G. and Upton, B.G.J., 1987. Alkaline igneous rocks.

Ghosh, J. G., 2004. 3.56 Ga tonalite in the central part of the Bastar craton, India: oldest Indian date. Journal of Asian Earth Sciences, 23(3), pp.359-364.

Ghosh, J.G., de Wit, M.J. and Zartman, R.E., 2004. Age and tectonic evolution of Neoproterozoic ductile shear zones in the Southern Granulite Terrain of India, with implications for Gondwana studies. Tectonics, 23(3).

Goswami, J. N., S. Mishra, M. Wiedenbeck, S. L. Ray, and A. K. Saha. 1995 "3.55 Ga Old Zircon from Singhbhum-Orissa Iron Ore Craton, Eastern India.” Current Science 69(12) pp.008-012.

Grady, J.C., 1971. Deep main faults in South India. Journal of Geological Society of India, 12, pp.56-62.

Heaman, L.M., Srivastava, R.K. and Sinha, A.K., 2002. A precise U$\mathrm{Pb}$ zircon/baddeleyite age for the Jasra igneous complex, KarbiAnalong District, Assam, NE India. Current Science, pp.744-748.

Heilimo, E., Mikkola, P., Huhma, H. and Halla, J., 2017. Alkalinerich quartz syenite intrusions of the Western Karelia subprovince. Geological Society, London, Special Publications, 449(1), pp.6188.

Hippe, K., Möller, A., Von Quadt, A., Peytcheva, I. and Hammerschmidt, K., 2016. Zircon geochronology of the Koraput alkaline complex: insights from combined geochemical and U$\mathrm{Pb}-\mathrm{Hf}$ isotope analyses, and implications for the timing of alkaline magmatism in the Eastern Ghats Belt, India. Gondwana Research, 34, pp.205-220.

Isshiki, M., Irifune, T., Hirose, K., Ono, S., Ohishi, Y., Watanuki, T., Nishibori, E., Takata, M. and Sakata, M., 2004. Stability of magnesite and its high-pressure form in the lowermost mantle. Nature, 427(6969), p.60.

Kovach, V.P., Santosh, M., Salnikova, E.B., Berezhnaya, N.G., Bindu, R.S., Yoshida, M. and Kotov, A.B., 1998. U-Pb zircon age of the Puttetti alkali syenite, southern India. Gondwana Research, 3(1), pp.408-410.

Krishnamurthy, P., Hoda, S.Q., Sinha, R.P., Banerjee, D.C. and Dwivedy, K.K., 2000. Economic aspects of carbonatites of India. Journal of Asian Earth Sciences, 18(2), pp.229-235.

Kumar, A. and Gopalan, K., 1991. Precise Rb-Sr age and enriched mantle source of the Sevattur carbonatites, Tamil Nadu, South India. Current Science (Bangalore), 60(11), pp.653-655.

Kumar, A., Charan, S.N., Gopalan, K. and Macdougall, J.D., 1998. A long-lived enriched mantle source for two Proterozoic carbonatite complexes from Tamil Nadu, southern India. Geochimica et Cosmochimica Acta, 62(3), pp.515-523.

Le Bas, M., Maitre, R.L., Streckeisen, A., Zanettin, B. and IUGS Subcommission on the Systematics of Igneous Rocks, 1986. A chemical classification of volcanic rocks based on the total alkali- silica diagram. Journal of petrology, 27(3), pp.745-750.

Lee, W.J. and Wyllie, P.J., 1994. Experimental data bearing on liquid immiscibility, crystal fractionation, and the origin of calciocarbonatites and natrocarbonatites. International Geology Review, 36(9), pp.797-819.

Leelanandam, C., 1989. The Prakasam Alkaline Province in Andhra Pradesh, India. Geological Society of India; 34(1).

Leelanandam, C., 1990. The Kandra volcanics in Andhra Pradesh: possible ophiolite?. Current Science, 59(16), pp.785-788.

Leelanandam, C., Burke, K., Ashwal, L.D. and Webb, S.J., 2006. Proterozoic mountain building in Peninsular India: an analysis based primarily on alkaline rock distribution. Geological Magazine, 143(2), pp.195-212.

Madhavan, V., Srinivas, M., Mallikharjuna Rao, J. and Chalapathi Rao, N.V., 1995. Mineral chemistry and Geochemistry of the Mesocratic quartz syenite intrusions from Vikurthi and Kotappakonda, Guntur District, Andhra Pradesh. Journal Geological Society of India, 45, pp.519-519.

Mazumder, S.K., Rao, T.K. and Nathan, N.P., 2000. Alkaline complexes of southern and Eastern India: an overview. Geological Survey of India, Special Publications, 55, pp.101-134.

Menzies, M., 1987. Alkaline rocks and their inclusions: a window on the Earth's interior. Geological Society, London, Special Publications, 30(1), pp.15-27.

Mezger, K., and Cosca, M., 1999. The thermal history of the Eastern Ghats Belt (India), as revealed by U-Pb and ${ }^{40} \mathrm{Ar} /{ }^{39} \mathrm{Ar}$ dating of metamorphic and magmatic minerals: implications for the SWEAT correlation. Precambrian Res. 94, pp. 251-271

Millot, R., Allègre, C.J., Gaillardet, J. and Roy, S., 2004. Lead isotopic systematics of major river sediments: a new estimate of the $\mathrm{Pb}$ isotopic composition of the Upper Continental Crust. Chemical Geology, 203(1-2), pp.75-90.

Mitchell, R.H. and Chakrabarty, A., 2012. Paragenesis and decomposition assemblage of a Mn-rich eudialyte from the Sushina peralkaline nepheline syenite gneiss, Paschim Banga, India. Lithos, 152, pp.218-226.

Miyazaki, T., and Santosh, M., 2005. Cooling history of the Puttetti alkali syenite pluton, southern India. Gondwana Research 8(4), pp.567-574.

Miyazaki, T., Kagami, H., Shuto, K., Morikiyo, T., Mohan, V.R. and Rajasekaran, K.C., 2000. Rb-Sr geochronology, Nd-Sr isotopes and whole rock geochemistry of Yelagiri and Sevattur syenites, Tamil Nadu, south India. Gondwana Research, 3(1), pp.39-53.

Miyazaki, T., Kagami, H., Mohan, V.R., Shuto, K. and Morikiyo, T., 2003. Enriched subcontinental lithospheric mantle in the northern part of the South Indian Granulite Terrain: evidence from Yelagiri and Sevattur syenite plutons, Tamil Nadu, South India. Gondwana Research, 6(4), pp.585-594.

Möller, A., Geisler, T., Schleicher, H., Todt, W., Viladkar, S.G. and Subramanian, V., 2001. Inter-relationship between carbonatitepyroxinite-syenite complexes of southern India. Symposuim on Carbonatites and Associated Alkaline Rocks and Field Workshop on Carbonatites of Tamil Nadu, Chennai, India, 15-16 (abstract).

Moralev, V.M., Voronovski, S.N. and Borodin, L.S., 1975. New findings about the age of carbonatites and syenites from southern India. In USSR Acad. Sci., 222, pp.46-48.

Mukhopadhyay, S., Ray, J., Chattopadhyay, B., Sengupta, S., Ghosh, B. and Mukhopadhyay, S., 2011a. Significance of mineral chemistry of syenites and associated rocks of Elagiri Complex, Southern Granulite Terrane of the Indian Shield. Journal of the Geological Society of India, 77(2), pp.113-129.

Mukhopadhyay, S., Ray, J., Balaram, V., Krishna, A.K., Ghosh, B. and Mukhopadhyay, S., 2011b. Geochemistry and petrogenesis of syenites and associated rocks of the Elagiri complex, Southern 
Granulite Terrane, India. Journal of Asian Earth Sciences, 42(6), pp.1256-1270.

Nair, N.G.K., Santosh, M. and Thampi, P.K., 1984. Alkali granitesyenite-carbonatite association in Munnar Kerala, India; implications for rifting, alkaline magmatism and liquid immiscibility. Proceedings of the Indian Academy of SciencesEarth and Planetary Sciences, 93(2), p.149.

Nanda, J., Gupta, S. and Dobmeier, C.J., 2008. Metamorphism of the Koraput Alkaline Complex, Eastern Ghats Province, Indiaevidence for reworking of a granulite terrane. Precambrian Research, 165(3-4), pp.153-168.

Naqvi, S.M. and Rogers, J.J.W., 1987. Precambrian geology of India. Oxford University Press.

Natarajana, M., Rao, B.B., Parthasarathy, R., Kumar, A. and Gopalan, K., 1994. 2.0 Ga old pyroxenite-carbonatite complex of Hogenakal, Tamil Nadu, South India. Precambrian Research, 65(1-4), pp.167-181.

Nelson, D.R., Chivas, A.R., Chappell, B.W. and McCulloch, M.T., 1988. Geochemical and isotopic systematics in carbonatites and implications for the evolution of ocean-island sources. Geochimica et Cosmochimica Acta, 52(1), pp.1-17.

Niyogi, D., 1966. Petrology of the alkalic rocks of Kishangarh, Rajasthan, India. Geological Society of America Bulletin, 77(1), pp.65-82.

Odom, A.L., 1982. Isotope age determinations of rock and mineral samples from Kerala, India. Final Report United Nations Case, (81-10084), p.10.

Pandit, M.K. and Golani, P.R., 2001. Reappraisal of the petrologic status of Newania 'carbonatite' of Rajasthan, western India. Journal of Asian Earth Sciences, 19(3), pp.305-310.

Pandit, M.K., Sial, A.N., Sukumaran, G.B., Pimentel, M.M., Ramasamy, A.K. and Ferreira, V.P., 2002. Depleted and enriched mantle sources for Paleo-and Neoproterozoic carbonatites of southern India: $\mathrm{Sr}, \mathrm{Nd}, \mathrm{C}-\mathrm{O}$ isotopic and geochemical constraints. Chemical geology, 189(1-2), pp.69-89.

Pandit, M.K., Sial, A.N., Sukumaran, G.B., Ramanathan, S. and Ferreira, V. P., 1998. Carbon and oxygen isotopic variation in Tamil Nadu carbonatites, South India. Current science, 74(7), pp.620-624.

Peucat, J.J., Mahabaleswar, B. and Jayananda, M., 1993. Age of younger tonalitic magmatism and granulitic metamorphism in the South Indian transition zone (Krishnagiri area); comparison with older Peninsular gneisses from the Gorur-Hassan area. Journal of Metamorphic Geology, 11(6), pp.879-888.

Phadke, A.V. and Jhingran, A.G., 1968. On the carbonatite at Newania, Udaipur district, Rajasthan. Geological Society of India, 9(2), pp.165-170.

Radhakrishna, B. P. and S. M. Naqvi., 1986. Precambrian Continental Crust of India and Its Evolution. The Journal of Geology. 94(2) pp.145-166.

Rajesh, H.M., 2003. Outcrop-scale silicate liquid immiscibility from an alkali syenite (A-type granitoid)-pyroxenite association near Puttetti, Trivandrum Block, South India. Contributions to Mineralogy and Petrology, 145(5), pp.612-627.

Ramakrishnan, M., Nanda, J.K. and Augustine, P.F., 1998. Geological evolution of the Proterozoic Eastern Ghats mobile belt. Geological Survey of India, Special Publication, 44, pp.1-21.

Ranjan, S., Upadhyay, D., Abhinay, K., Pruseth, K.L. and Nanda, J.K., 2018. Zircon geochronology of deformed alkaline rocks along the Eastern Ghats Belt margin: India-Antarctica connection and the Enderbia continent. Precambrian Research, 310, pp.407424.

Ratnakar, J. and Leelanandam, C., 1986. A petrochemical study of the purimetla alkaline pluton, prakasam district, Andhra Pradesh,
India. Neues Jahrbuch für Mineralogie - Abhandlungen, 156(1), pp.99-119.

Ravindran, K.R., 1986. Studies on Carbonatite rocks of Pakkanadu Salem district Tamil Nadu.

Ray, J.S. and Ramesh, R., 2006. Stable carbon and oxygen isotopic compositions of Indian carbonatites. International Geology Review, 48(1), pp.17-45.

Ray, J.S., Ramesh, R., Pande, K., Trivedi, J.R., Shukla, P.N. and Patel, P.P., 2000. Isotope and rare earth element chemistry of carbonatite-alkaline complexes of Deccan volcanic province: implications to magmatic and alteration processes. Journal of Asian Earth Sciences, 18(2), pp.177-194.

Ray, J.S., Pande, K., Bhutani, R., Shukla, A.D., Rai, V.K., Kumar, A., Awasthi, N., Smitha, R.S. and Panda, D.K., 2013. Age and geochemistry of the Newania dolomite carbonatites, India: implications for the source of primary carbonatite magma. Contributions to Mineralogy and Petrology, 166(6), pp.16131632.

Renjith, M.L., Charan, S.N., Subbarao, D.V., Babu, E.V.S.S.K. and Rajashekhar, V.B., 2014. Grain to outcrop-scale frozen moments of dynamic magma mixing in the syenite magma chamber, Yelagiri Alkaline Complex, South India. Geoscience Frontiers, 5(6), pp.801-820.

Renjith, M.L., Santosh, M., Li, T., Satyanarayanan, M., Korakoppa, M.M., Tsunogae, T., Rao, D.S., Krishna, A.K. and Charan, S.N., 2016a. Zircon U-Pb age, Lu-Hf isotope, mineral chemistry and geochemistry of Sundamalai peralkaline pluton from the Salem Block, southern India: Implications for Cryogenian adakite-like magmatism in an aborted-rift. Journal of Asian Earth Sciences, 115, pp.321-344.

Renjith, M.L., Santosh, M., Satyanarayanan, M., Rao, D.S. and Tang, L., 2016b. Multiple rifting and alkaline magmatism in southern India during Paleoproterozoic and Neoproterozoic. Tectonophysics, 680, pp.233-253.

Rudnick, R.L. and Goldstein, S.L., 1990. The Pb isotopic compositions of lower crustal xenoliths and the evolution of lower crustal $\mathrm{Pb}$. Earth and Planetary Science Letters, 98(2), pp.192-207.

Sai, V.S., 2017. Hornblende bearing quartz syenite from the Proterozoic Podili alkali granite pluton, Eastern Dharwar Craton, India. Editorial Advisory Board (2016-2017), 71(4), pp.563-574.

Santosh, M., Iyer, S.S., Vasconcellos, M.B.A. and Enzweiler, J., 1989. Late Precambrian alkaline plutons in southwest India: geochronologic and rare-earth element constraints on Pan-African magmatism. Lithos, 24(1), pp.65-79.

Santosh, M., Yang, Q.Y., Mohan, M.R., Tsunogae, T., Shaji, E. and Satyanarayanan, M., 2014. Cryogenian alkaline magmatism in the Southern Granulite Terrane, India: Petrology, geochemistry, zircon U-Pb ages and Lu-Hf isotopes. Lithos, 208, pp.430-445.

Sarkar, A., Paul, D.K., Bishui, P.K., Gupta, S.N. and Nanda, J.K., 1989. Late Proterozoic alkaline magmatism in the Eastern Ghats Belt: $\mathrm{Rb}$-Sr isotopic study on the Koraput complex, Orissa. Indian Minerals, 43(3-4), pp.265-272.

Sarkar, A. and Bhattacharya, S.K., 1992. Carbonatites from Rajasthan indicate mantle carbon-and oxygen-isotope composition. Current Science, pp.368-370.

Schleicher, H., Todt, W., Viladkar, S.G. and Schmidt, F., 1997. Pb/Pb age determinations on the Newania and Sevattur carbonatites of India: evidence for multi-stage histories. Chemical Geology, 140(3-4), pp.261-273.

Schleicher, H., Kramm, U., Pernicka, E., Schidlowski, M., Schmidt, F., Subramanian, V., Todt, W. and Viladkar, S.G., 1998. Enriched subcontinental upper mantle beneath southern India: evidence from $\mathrm{Pb}, \mathrm{Nd}, \mathrm{Sr}$, and $\mathrm{C}-\mathrm{O}$ isotopic studies on Tamil $\mathrm{Nadu}$ carbonatites. Journal of Petrology, 39(10), pp.1765-1785. 
Sen, G., Bizimis, M., Das, R., Paul, D.K., Ray, A. and Biswas, S., 2009. Deccan plume, lithosphere rifting, and volcanism in Kutch, India. Earth and Planetary Science Letters, 277(1-2), pp.101-111.

Sharma, V.N. and Ratnakar, J., 2000. Petrology of the gabbro-dioritesyenite-granite complex of Chanduluru, Prakasam alkaline province, Andhra Pradesh, India. Journal of the Geological Society of India, 55(5), pp.553-572.

Sheikh, J.M., Champati, A.K., Patel, S.C., Prabhakar, N. and Gerdes, A., 2017. Structure, petrology and U-Pb zircon age of Mesoproterozoic nepheline syenites from the Rengali Province, eastern India: Implications for their petrogenesis and geodynamic evolution. In EGU General Assembly Conference Abstracts,19, p. 17065 .

Simmat, R. and Raith, M.M., 2008. U-Th-Pb monazite geochronometry of the Eastern Ghats Belt, India: timing and spatial disposition of poly-metamorphism. Precambrian Research, 162(1-2), pp.16-39.

Smithies, R.H. and Champion, D.C., 1999. Late Archaean felsic alkaline igneous rocks in the Eastern Goldfields, Yilgarn Craton, Western Australia: a result of lower crustal delamination?. Journal of the Geological Society, 156(3), pp.561-576.

Sørensen, H., 1974. Alkali syenites, feldspathoidal syenites and related lavas. The alkaline rocks, pp.22-52.

Sreejith, C. and Kumar, G.R., 2009. Petrological and geochemical characteristics of Marunthurkota syenites from the Kerala Khondalite Belt, southern India. Journal of the Geological Society of India, 73(3), p.386.

Sridhar, N., Reddy, R.M. and Nagendrababu, G., 2018. Quartz syenites from the Prakasam alkaline province, Southern India; A comparative study with special emphasis on their rare earth element contents. Journal of Indian Geophysical Union, 22(5), pp.507-517.

Srivastava, R.K., 1993. Chemical classification for silica rich carbonatites. Indian Journal of Geochemistry, 8, pp.15-24.

Srivastava, R.K., 1998. Petrology of the Proterozoic alkaline carbonatite complex of Samalpatti, district Dharmapuri, Tamil Nadu. Journal of the Geological Society of India, 51, pp.233244.

Srivastava, R.K., Mohan, A. and Filho, C.F.F., 2005. Hot-fluid driven metasomatism of samalpatti carbonatites, South India: Evidence from petrology, mineral chemistry, trace elements and stable isotope compositions. Gondwana Research, 8(1), pp.77-85.

Srivastava, R.K. and Sinha, A.K., 2007. Nd and Sr isotope systematics and geochemistry of a plume-related Early Cretaceous alkalinemafic-ultramafic igneous complex from Jasra, Shillong Plateau, northeastern India. Special papers-Geological Society of America, 430, p.815.

Streckeisen, A., 1980. Classification and nomenclature of volcanic rocks, lamprophyres, carbonatites and melilitic rocks IUGS Subcommission on the systematics of igneous rocks. Geologische Rundschau, 69(1), pp.194-207.

Subba Rao, T.V., Bhaskar Rao, Y.J., Sivaraman, T.V. and Gopalan, K., 1989. Rb-Sr age and petrology of the Elchuru Alkaline Complex: implications to alkaline magmatism in the Eastern Ghat Mobile Belt. Memoirs - Geological Society of India, 15, pp.207223.

Subramaniam, V., Viladkar, S.G. and Upendran, R., 1978. Carbonatite Alkali Complex of Samalpatti Dharmapuri District, Tamil Nadu. Geological Society of India, 19(5), pp.206-216.

Sukheswala, R.N. and Viladkar, S.G., 1978. Carbonatites of India. In Proceedings 1st International Symposium on Carbonatites, Brazil (pp. 277-293).

Sun, S.S. and McDonough, W.F., 1989. Chemical and isotopic systematics of oceanic basalts: implications for mantle composition and processes. Geological Society, London, Special Publications, 42(1), pp.313-345.

Suresh, G., Ananthanarayana, R., Hanumanthu, R.C., Ghosh, S., Kumar, A.A. and Reddy, K.V.S., 2010. Geology of Pulikonda and Dancherla Alkaline Complexes, Andhra Pradesh. Journal of the Geological Society of India, 75(4), pp.576-595.

Sutcliffe, R.H., Smith, A.R., Doherty, W. and Barnett, R.L., 1990. Mantle derivation of Archean amphibole-bearing granitoid and associated mafic rocks: evidence from the southern Superior Province, Canada. Contributions to Mineralogy and Petrology, 105(3), pp.255-274.

Taylor H. P., Frechen J. and Degens E.T., 1967 Oxygen and carbon isotope studies of carbonatites from the Laacher See district, West Germany and the Alnö district, Sweden. Geochimica et Cosmochimica Acta. 31(3) pp.407-430.

Udas, G.R. and Krishnamurthy, P., 1970. Carbonatites of Sevattur and Jokipatti, madras state, India (No. CONF-681088-6). University of Saugar, India.

Upadhyay, D., 2008. Alkaline magmatism along the southeastern margin of the Indian shield: implications for regional geodynamics and constraints on craton-Eastern Ghats Belt suturing. Precambrian Research, 162(1-2), pp.59-69.

Upadhyay, D. and Raith, M.M., 2006a. Intrusion age, geochemistry and metamorphic conditions of a quartz-monzosyenite intrusion at the craton-Eastern Ghats Belt contact near Jojuru, India. Gondwana Research, 10(3-4), pp.267-276.

Upadhyay, D. and Raith, M.M., 2006b. Petrogenesis of the Kunavaram alkaline complex and the tectonothermal evolution of the neighboring Eastern Ghats Belt granulites, SE India. Precambrian Research, 150(1-2), pp.73-94.

Upadhyay, D., Raith, M.M., Mezger, K., Bhattacharya, A. and Kinny, P.D., 2006a. Mesoproterozoic rifting and Pan-African continental collision in SE India: evidence from the Khariar alkaline complex. Contributions to Mineralogy and Petrology, 151(4), pp.434-456.

Upadhyay, D., Raith, M.M., Mezger, K. and Hammerschmidt, K., 2006b. Mesoproterozoic rift-related alkaline magmatism at Elchuru, Prakasam alkaline province, SE India. Lithos, 89(3-4), pp.447-477.

Upadhyay, D., Jahn-Awe, S., Pin, C., Paquette, J.L. and Braun, I., 2006c. Neoproterozoic alkaline magmatism at Sivamalai, southern India. Gondwana Research, 10(1-2), pp.156-166.

Veena, K., Pandey, B.K., Krishnamurthy, P. and Gupta, J.N., 1998. $\mathrm{Pb}, \mathrm{Sr}$ and $\mathrm{Nd}$ isotopic systematics of the carbonatites of Sung Valley, Meghalaya, northeast India: Implications for contemporary plume-related mantle source characteristics. Journal of Petrology, 39(11-12), pp.1875-1884.

Vijaya Kumar, K., Carol D.F., Frost B.R. and Kevin R.C., 2007. The Chimakurti, Errakonda, and Uppalapadu Plutons, Eastern Ghats Belt, India: An Unusual Association of Tholeiitic and Alkaline Magmatism. Lithos 97(1) pp.30-57.

Vijaya Kumar, K. and Leelanandam, C., 2008, Evolution of the Eastern Ghats Belt, India: A plate tectonic perspective: Journal of the Geological Society of India. 72(6), pp.720-749.

Vijaya Kumar, K., Leelanandam, C. and Ernst, W.G., 2011. Formation and fragmentation of the Palaeoproterozoic supercontinent Columbia: evidence from the Eastern Ghats Granulite Belt, southeast India. International Geology Review, 53(11-12), pp.1297-1311.

Viladkar, S.G. and Wimmenauer, W., 1986. Mineralogy and geochemistry of the Newania carbonatite-fenite complex, Rajasthan, India. Neues Jahrbuch für Mineralogie Abhandlungen, 156, pp.1-21.

Viladkar, S.G. and Subramanian, V., 1995. Mineralogy and geochemistry of the carbonatites of the Sevattur and Samalpatti 
complexes, Tamil-Nadu. Journal of the Geological Society of India, 45(5), pp.505-517.

Viladkar, S.G., 1998. Carbonatite occurrences in Rajasthan, India. Petrology, 6(3), pp.272-283.

Vladykin, N.V., Viladkar, S.G., Miyazaki, T. and Mohan, V.R., 2008. Geochemistry of benstonite and associated carbonatites of Sevattur, Jogipatti and Samalpatti, Tamil Nadu, south India and Murun massif, Siberia. Journal of the Geological Society of India, 72(3), pp.312-324.

Vrublevskii, V.V., Reverdatto, V.V., Izokh, A.E., Gertner, I.F., Yudin, D.S. and Tishin, P.A., 2011, April. Neoproterozoic carbonatite magmatism of the Yenisei Ridge, Central Siberia: ${ }^{40} \mathrm{Ar} /{ }^{39} \mathrm{Ar}$ geochronology of the Penchenga rock complex. In Doklady Earth Sciences,437, p.443. SP MAIK Nauka/Interperiodica.

Wallace, M.E. and Green, D.H., 1988. An experimental determination of primary carbonatite magma composition. Nature, 335(6188), p.343.

Woolley, A.R., Kempe, D.R.C., 1989. Carbonatites: nomenclature, average chemical compositions, and element distribution. In: Bell, K. (ed.) Carbonatites: Genesis and Evolution. Unwin Hyman, London. pp.1-14.

Woolley, A.R., 2001. Alkaline rocks and carbonatites of the world. Part 3: Africa. Geological Society. Natural History Museum, London.

Woolley, A.R., Kjarsgaard, B.A., 2008. Paragenetic types of carbonatite as indicated by the diversity and relative abundances of associated silicate rocks: Evidence from a global database. The Canadian Mineralogist. 46(4), pp.741-752.

Wu, F.Y., Yang, Y.H., Li, Q.L., Mitchell, R.H., Dawson, J.B., Brandl, G. and Yuhara, M., 2011. In situ determination of U-Pb ages and $\mathrm{Sr}-\mathrm{Nd}-\mathrm{Hf}$ isotopic constraints on the petrogenesis of the Phalaborwa carbonatite Complex, South Africa. Lithos, 127(12), pp.309-322.

Zindler, A. and Hart, S., 1986. Chemical geodynamics. Annual review of earth and planetary sciences, 14(1), pp.493-571.

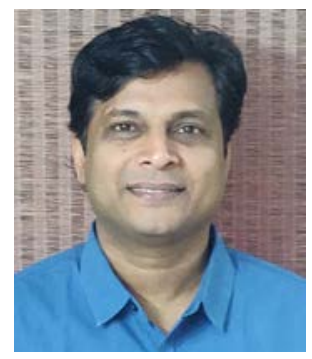

Dr.Debajyoti Paul is a Professor at the Department of Earth Sciences, Indian Institute of Technology Kanpur. His main research interest is to understand the evolution of the crust-mantle system by studying the geochemical signatures preserved in the mantle-derived rocks. Currently, he and his Ph.D. students are working to understand the geochemical evolution of the Indian subcontinent. He has published around 60 papers and articles in peer-reviewed journals.

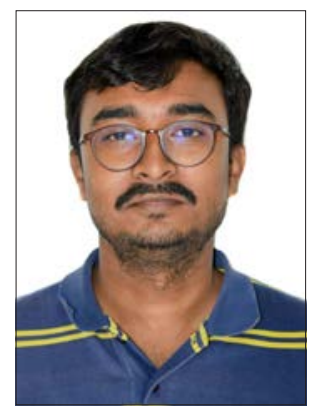

Mahesh Halder is a Senior Research Fellow (SRF) and a Ph.D. student in the Department of Earth Sciences, IIT Kanpur, India.Hewas awarded a JRF/SRF fellowship by the Council of Scientific \& Industrial Research (CSIR), MHRD, Govt. of India. His areas of interestsare petrology and geochemistry of igneousrocks with special emphasis on the crust-mantle interaction and origin of Large Igneous Provinces.

\section{Abbreviations used in the manuscript}

$\begin{array}{ll}\text { ARCs } & \text { : Alkaline rocks and carbonatites } \\ \text { DARCs } & : \text { Deformed alkaline rocks and carbonatites } \\ \text { EGMB } & : \text { Eastern Ghats Mobile Belt } \\ \text { SGT } & : \text { Southern Granulite Terrain } \\ \text { KZ } & : \text { Khondalite zone } \\ \text { MZ } & : \text { Migmatite zone } \\ \text { WCZ } & : \text { Western charnockite zone } \\ \text { TZ } & : \text { Transition zone } \\ \text { EGP } & : \text { Eastern Ghats Province } \\ \text { EDC } & : \text { Eastern Dharwar Craton } \\ \text { PCSZ } & : \text { Palghat-Cauvery shear zone } \\ \text { KKPT } & : \text { Karur-Kambam-Painavu-Trichur shear zone } \\ \text { TAS } & : \text { Total alkali versus silica } \\ \text { REE } & : \text { Rare earth elements } \\ \text { LREE } & : \text { Light rare earth elements } \\ \text { DMM } & : \text { Depleted MORB mantle } \\ \text { HIMU } & : \text { high } \mu \text {, } \mu \text { = }{ }^{238} \text { U } 204 \text { Pb } \\ \text { EMI } & : \text { Enriched mantle I } \\ \text { EMII } & : \text { Enriched mantle II } \\ \text { UCC } & : \text { Upper continental crust } \\ \text { LCC } & : \text { Lower continental crust } \\ \text { BSE } & : \text { Bulk silicate Earth } \\ \text { LILE } & : \text { Large ion lithophile elements } \\ \text { HFSE } & : \text { High field strength elements } \\ \text { SCLM } & : \text { Subcontinental lithospheric mantle } \\ \text { LIPs } & : \text { Large Igneous Provinces } \\ \end{array}$

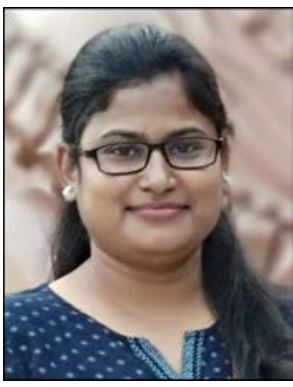

Jyoti Chandra, Ph.D.,is a Research Associate-I at the National Geophysical Research Institute, India. She received Ph.D. from the Department of Earth Sciences, Indian Institute of Technology Kanpur with funding from CSIR-JRF and GATE fellowships. Her main research focuses on the geochemical and isotopic ( $\mathrm{Sr}-\mathrm{Nd}-\mathrm{Pb}-\mathrm{C}$ O) studies of carbonatites and associated silicate rocks and basalt to understand their origin. She has published two papers in international journals. 